Influence of Rock Composition on the Geochemistry of Stream and Spring Waters from M ountainous Watersheds in the Gunnison, Uncompahgre, and Grand Mesa National Forests, Colorado

U.S. Geological Survey Professional Paper 1667 


\title{
Influence of Rock Composition on the Geochemistry of Stream and Spring Waters from M ountainous W atersheds in the Gunnison, Uncompahgre, and Grand Mesa National Forests, Colorado
}

\author{
By William R. Miller
}

U.S. Geological Survey Professional Paper 1667 


\section{U.S. Department of the Interior}

Gale A. Norton, Secretary

\section{U.S. Geological Survey}

Charles G. Groat, Director

This publication is available online at:

http://geology.cr.usgs.gov/pub/ppapers/p1667/

Version 1.02002

Any use of trade, product, or firm names in this publication is for descriptive purposes only and

does not imply endorsement by the U.S. Government

Published in the Central Region, Denver, Colorado

Manuscript approved for publication June 18, 2002

Graphics by author and Gayle M. Dumonceaux

Photocomposition by Gayle M. Dumonceaux 


\section{Contents}

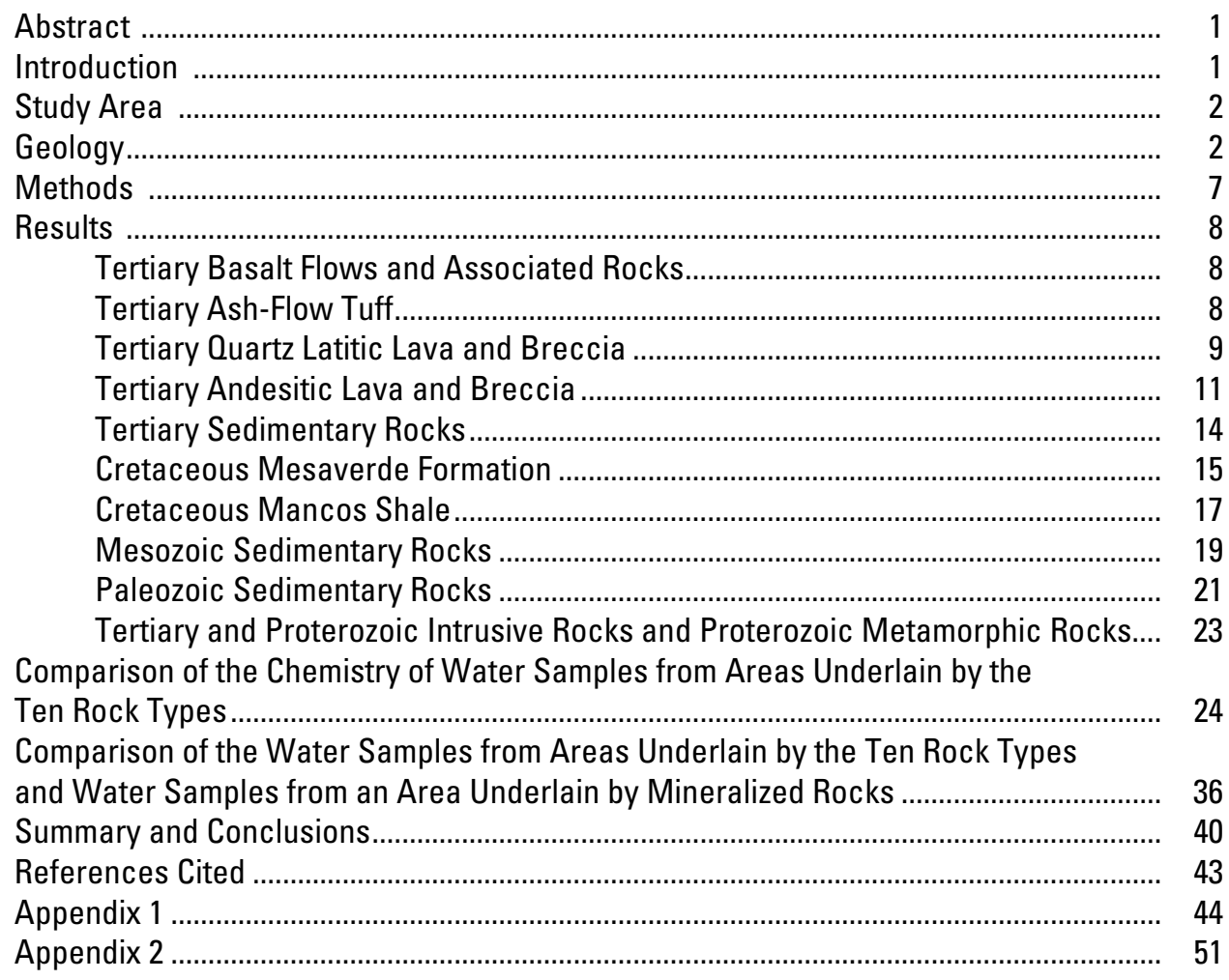

\section{Figures}

1. Map showing locations of the Gunnison, Uncompahgre, and Grand Mesa National Forests

2-4. Generalized geologic maps:

2. Grand Mesa National Forest.

3. Uncompahgre National Forest............................................................................ 5

4. Gunnison National Forest .................................................................................. 6

5-16. Site localities of:

5. Stream water samples from areas underlain by Tertiary basalt flows and associated rocks, Grand Mesa National Forest

6. Stream and spring water samples from areas underlain by Tertiary ash-flow tuff in the Los Pinos and Pauline Creek watersheds, Gunnison National Forest.

7. Stream water samples from areas underlain by Tertiary quartz latitic lava and breccia in the Mineral Creek Watershed, Gunnison National Forest .... 12

8. Stream water samples from areas underlain by Tertiary andesitic lava and breccia in the Soap Creek watershed, Gunnison National Forest 
9. Stream water samples from areas underlain by Eocene Green River and Wasatch Formations and Upper Cretaceous Ohio Creek Member of Mesaverde Formation in the Buzzard Creek watershed, Grand Mesa National Forest

10. Stream and spring water samples from areas underlain by Cretaceous Mesaverde Formation in the Coal Creek and Snowshoe Creek watersheds, Gunnison National Forest

11. Stream water samples from areas underlain by Cretaceous Mancos Shale in the Beaver and Goat Creek watersheds, Uncompahgre National Forest

12. Stream water samples from areas underlain by Cretaceous Mancos Shale in the Bell Creek area, Gunnison National Forest

13. Stream and spring water samples from areas underlain by Mesozoic sedimentary rocks along the top and east flank of the Uncompahgre Plateau, Uncompahgre National Forest

14. Stream and spring water samples from areas underlain by Paleozoic sedimentary rocks, in the Cement Creek watershed, Gunnison National Forest

15. Stream water samples from areas underlain by Tertiary and Proterozoic intrusive rocks and Proterozoic metamorphic rocks in the Quartz Creek area, Gunnison National Forest

16. Stream and spring water samples from areas underlain by Proterozoic intrusive and metamorphic rocks along the western flank of the Sawatch Range, Gunnison National Forest

17-19. Potential release of total dissolved solids (TDS) in stream and spring waters:

17. Grand Mesa National Forest...

18. Uncompahgre National Forest ................................................................. 31

19. Gunnison National Forest ............................................................................. 32

20-22. Mean $\mathrm{pH}$ values of stream and spring waters:

20. Grand Mesa National Forest.................................................................... 33

21. Uncompahgre National Forest .......................................................................... 34

22. Gunnison National Forest ......................................................................... 35

23-25. Acid-neutralizing capacity to introduced acidity:

23. Grand Mesa National Forest.

24. Uncompahgre National Forest ..................................................................... 37

25. Gunnison National Forest ............................................................................. 38

\section{Tables}

1. Generalized stratigraphic column of dominant rock types in the Grand Mesa, Uncompahgre, and Gunnison National Forests

2. The ten dominant rock composition types in the Grand Mesa, Uncompahgre, and Gunnison National Forests

3. Background of trace metals in fresh water and chemical analyses of mean river water

4-13. Summary of the chemistry of:

4. Four stream water samples from watersheds underlain by Tertiary basalt flows and associated rocks

5. Three stream water samples and two spring water samples from watersheds underlain by Tertiary ash-flow tuff.

6. Four stream waters from watersheds underlain by Tertiary quartz latitic lava and breccia

7. Eight stream waters from watersheds underlain by Tertiary andesitic lava and breccia 
8. Seven stream waters from watersheds underlain by Tertiary sedimentary rocks.

9. Seven stream water samples and one spring water sample from areas underlain by the Cretaceous Mesaverde Formation

10. Eight stream water samples and two spring water samples from areas underlain by the Mancos Shale

11. One stream water sample and four spring water samples from areas underlain by Mesozoic sedimentary rocks

12. Fourteen stream water samples and one spring water sample from areas underlain by Paleozoic sedimentary rocks

13. Seven stream water samples and one spring water sample from areas underlain by Tertiary and Proterozoic intrusive and Proterozoic metamorphic rocks

14. Summary of the chemical analyses and other parameters of water samples from areas underlain by various rock composition types, Grand Mesa, Uncompahgre, and Gunnison National Forests

15. Mean normalized values for selected parameters and species in water samples from the three national forests and the Redcloud Peak area

16. Ranking of rock composition types with respect to potential release of total dissolved solids (TDS) and acid neutralizing capacity to introduced acidity in the three national forests

17. Chemical speciation of selected elements for water samples from the three national forests

18. Saturation indices of selected minerals for water samples from the three national forests

19. Summary of the chemistry of 19 stream water samples from areas underlain by the mineralized Sunshine Peak Tuff, a rhyolitic ash-flow tuff, Redcloud Peak area

20. Comparison of the geochemistry of water samples from areas underlain by unmineralized rocks in the three national forests and water samples from areas underlain by the mineralized Sunshine Peak Tuff, Redcloud Peak area.....

Metric Conversion Factors

\begin{tabular}{lll}
\hline Multiply & By & To obtain \\
\hline Foot (ft) & 1.609 & Meter $(\mathrm{m})$ \\
Inch (in.) & 0.3048 & Millimeters $(\mathrm{mm})$ \\
Mile (mi) & 2.54 & Kilometer $(\mathrm{km})$ \\
\hline
\end{tabular}

Temperature in degrees Celcius $\left({ }^{\circ} \mathrm{C}\right)$ can be converted to degrees Farenheit $\left({ }^{\circ} \mathrm{F}\right)$ as follows: ${ }^{\circ} \mathrm{F}=\left(1.8 \times{ }^{\circ} \mathrm{C}\right)+32$ 


\title{
Influence of Rock Composition on the Geochemistry of Stream and Spring Waters from M ountainous W atersheds in the Gunnison, Uncompahgre, and Grand Mesa National Forests, Colorado
}

\author{
By William R. Miller
}

\section{Abstract}

The ranges of geochemical baselines for stream and spring waters were determined and maps were constructed showing acid-neutralizing capacity and potential release of total dissolved solids for streams and spring waters for watersheds underlain by each of ten different rock composition types in the Gunnison, Uncompahgre, and Grand Mesa National Forests, Colorado (GMUG). Water samples were collected in mountainous headwater watersheds that have comparatively high precipitation and low evapotranspiration rates and that generally lack extensive ground-water reservoirs. Mountainous headwaters react quickly to changes in input of water from rain and melting snow and they are vulnerable to anthropogenic impact. Processes responsible for the control and mobility of elements in the watersheds were investigated. The geochemistry of water from the sampled watersheds in the GMUG, which are underlain by rocks that are relatively unmineralized, is compared to the geochemistry of water from the mineralized Redcloud Peak area.

The water with the highest potential for release of total dissolved solids is from watersheds that are underlain by Paleozoic sedimentary rocks; that high potential is caused primarily by gypsum in those rocks. Water that has the highest acid-neutralizing capacity is from watersheds that are underlain by Paleozoic sedimentary rocks. The water from watersheds underlain by the Mancos Shale has the next highest acid-neutralizing capacity. Water that has the lowest acid-neutralizing capacity is from watersheds that are underlain by Tertiary ash-flow tuff. Tertiary sedimentary rocks containing oil shale, the Mesavede Formation containing coal, and the Mancos Shale all contain pyrite with elevated metal contents. In these mountainous headwater areas, water from watersheds underlain by these rock types is only slightly impacted by oxidation of pyrite, and overall it is of good chemical quality. These geochemical baselines demonstrate the importance of rock composition in determining the types of waters that are in the headwater areas. The comparison of these geochemical baselines to later geochemical baselines will allow recognition of any significant changes in water quality that may occur in the future.

\section{Introduction}

In a mountainous watershed, precipitated water comes into contact with rock minerals and chemical weathering is initiated. Chemical weathering involves the congruent dissolution of minerals such as calcite, or the incongruent dissolution and transformation of minerals such as plagioclase to clay minerals. These chemical weathering processes release elements to the natural waters of a watershed. Therefore, the chemical compositions of natural waters in a watershed, in the absence anthropogenic input, are determined mostly by the chemical compositions of rocks in the drainage basin. In addition, minor input of dissolved species can come from atmospheric precipitation or dry fall. Biota activity in the soil concentrates $\mathrm{CO}_{2}$, and biota may concentrate or consume species. Other factors such as rates of mechanical erosion, the grain size and crystallinity of the rock minerals, the amount and distribution of precipitation, temperature, and type and amount of vegetation influence the rates of water-rock chemical interaction. However, the chemical composition of the rocks is the fundamental factor that determines the type of water that evolves in a headwater watershed. The major element compositions of most rock types are generally known from geologic maps, giving insight into the expected major element compositions of natural water in the drainage basin in question. Estimates for trace elements cannot be made from knowing the rock composition. Trace elements can vary two or more orders of magnitude within similar rock composition types.

The background geochemistry of natural water in a basin can be modified by input from anthropogenic processes such as nuclear fallout, atmospheric emission, or mining waste. There probably is no place in the world where the natural background composition of water has not been modified to some extent by anthropogenic processes; the effects of these processes always are superimposed on the natural background geochemistry. However, there are mountainous headwater areas that are only minimally affected by anthropogenic input. Headwater areas are the highest and the most remote regions of a watershed. There the water is imprinted by the chemical compositions of the rocks that underlie the watershed. Many of the headwater 
areas are critical to water resource development. Those areas have comparatively high precipitation and low evapotranspiration rates, and generally they lack extensive ground-water reservoirs because they are characterized by shallow soils and extensive outcrops of bedrock. The distribution of water in streams in the mountainous headwater areas is uneven throughout the year-high flows occur during the spring runoff and after summer thunderstorms. In the winter, water levels in streams and springs are a minimal; element concentrations are high but mass flux is low. At that time, runoff is maintained mainly by recession of the ground-water reservoir. Mountainous headwaters react quickly to changes in input of dissolved species and are especially vulnerable to anthropogenic impact.

Geochemical baselines, at a specific time and year for stream and spring waters, can be determined in these mountainous headwaters. These geochemical baselines can be used to understand processes responsible for the chemical compositions of water in a watershed. In addition, because water geochemistry is sensitive to changes in the environment, by monitoring water geochemistry in these mountainous headwater areas and comparing the results to earlier baseline data, changes in the environment within the basin can be determined. This geochemical baseline is an approximation of the natural background and if remediation is needed in the future because of anthropogenic contamination, this baseline is the ideal goal.

The purpose of this study is to determine, for different rock composition types, the range of chemical species and other geochemical parameters and to characterize the baseline geochemistry of stream and spring waters in mountainous watersheds in three national forests in western Colorado. The ranges of species and other parameters were determined for each of the major rock composition types in the Gunnison, Uncompahgre, and Grand Mesa National Forests (GMUG), and maps of mean $\mathrm{pH}$ values, potential release of total dissolved solids, and acidneutralizing capacity were constructed for each of the national forests. In addition, processes responsible for the control and mobility of the elements in the natural waters were investigated.

\section{Study Area}

The study area, in Western Colorado, includes the Gunnison, Uncompahgre, and Grand Mesa National Forests (fig. 1). The eastern part of the study area is in the Southern Rocky Mountains and the western part is in the Colorado Plateau physiographic province (Hunt, 1974). The mountain ranges and intermountain basins generally trend north-northwest. Dendritic drainage patterns are well developed, and most of the area is of moderate to high relief. Uncompahgre Peak, at 14,390 feet altitude, is the highest elevation in the study area. The lowest elevation is along the west flank of Battlement Mesa, at approximately 6000 feet altitude. The main river systems that drain the study area are the Uncompahgre, Gunnison, San Miguel, and Dolores Rivers. The river systems drain to the Colorado River beyond the limits of the study area. Annual precipitation ranges from approximately 20 in. in the northwestern part of the study area to more than 50 in. at the higher elevations (Colorado Climate Center, 1984). The higher elevations receive the highest

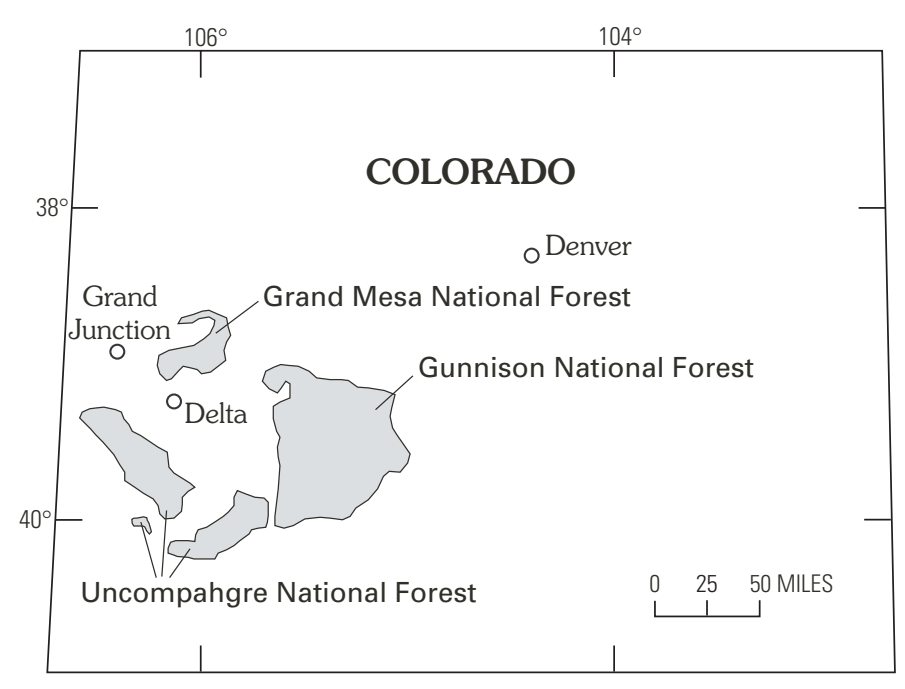

Figure 1. Map showing localities of the Gunnison, Umcompahre, and Grand Mesa National Forests, Colorado.

precipitation, mainly as snow during the winter. Winter weather is influenced by storm systems originating over the Pacific Ocean. Snow pack above 10,000 feet begins to accumulate in late October, and the maximum is in mid-April (Benedict, 1991). In summer, particularly in July, August, and early September, an influx of moist air from the Gulf of Mexico causes afternoon thunderstorms and storm runoff. Snowmelt runoff usually is from April through July, and it peaks in May and June (Apodaca and others, 1996).

Because of the large differences in altitude, the climate in the study area varies from cool-humid in the higher mountains to semi-arid at lower elevations. Mean annual temperature varies from approximately $32^{\circ} \mathrm{F}$ at the highest elevations to higher than $50^{\circ} \mathrm{F}$ at lower elevations (Benci and McKee, 1977). The natural vegetation in the study area is strongly zoned by altitude; it is divided into six general groups, based on the classification of the U.S. Department of Agriculture (1972). Except for grasslands, which are at both high and low elevations, the groups, from the highest to the lowest elevation, are 1, alpine tundra; 2, subalpine forest; 3 , pinyon pine-juniper forest; 4 , oak scrubland; 5, sagebrush scrubland; and 6, grassland. Timberline is approximately 11,000 feet; its altitude varies in relation to of slope orientation to sun, rock-to- soil cover, and other surface phenomena.

\section{Geology}

Geologic materials in the three national forests vary, from Proterozoic granite, quartz monzonite, schist, and gneiss to Quaternary unconsolidated sediments (table 1). The major bedrock types in the Grand Mesa National Forest (fig. 2) are, from youngest to oldest: 1, Pliocene and Miocene basalt flows and associated tuff, breccia, and conglomerate; 2 , sandstone and siltstone of the Eocene Uinta Formation; 3, marlstone, sandstone, and oil shale of the Eocene Green River Formation; 4, claystone, mudstone, and conglomerate of the Eocene Wasatch Formation and the Upper Cretaceous Ohio Creek Member of 


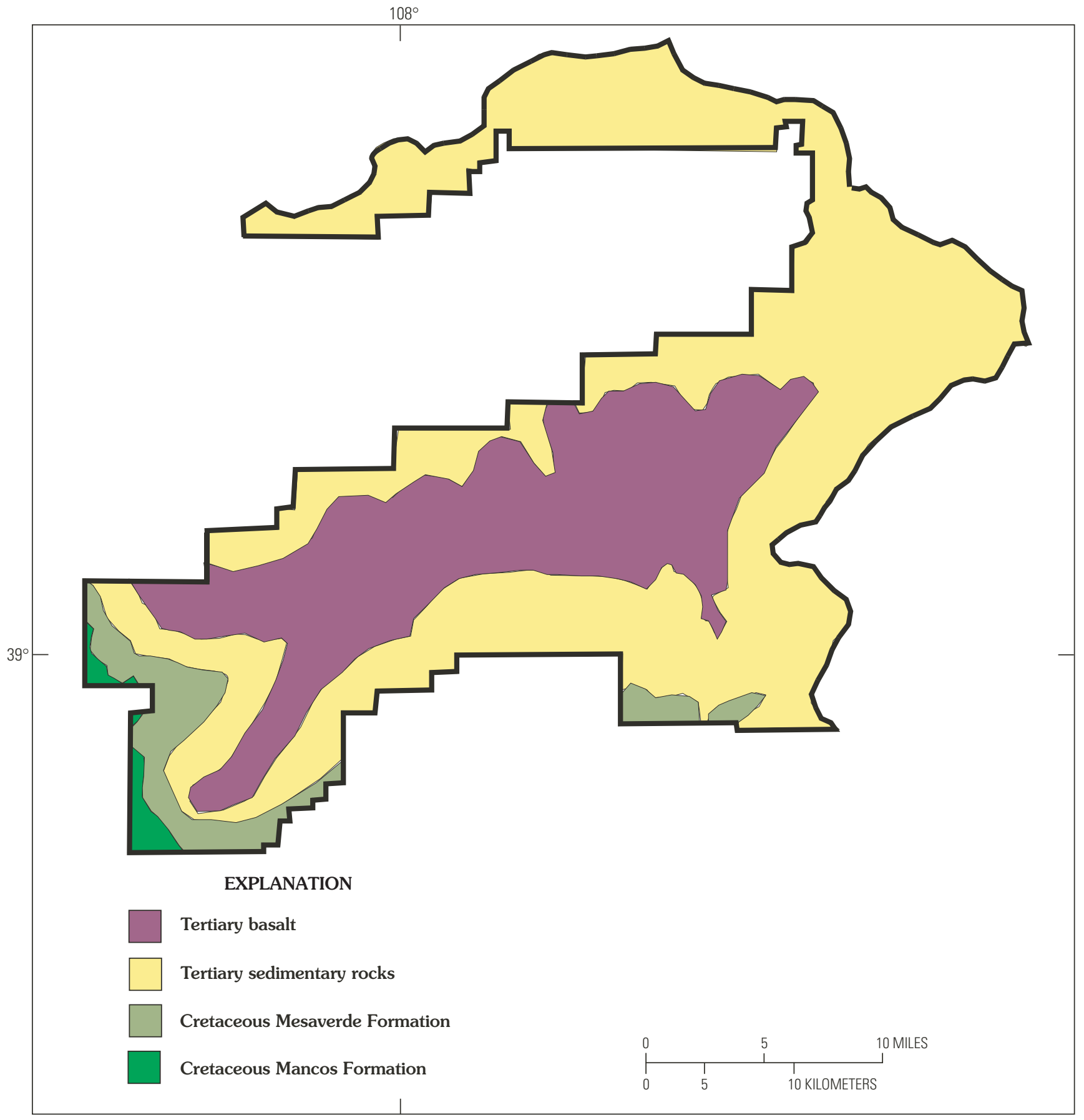

Figure 2. Generalized geologic map of the Grand Mesa National Forest, Colorado. Modified from Tweto (1979).

the Mesaverde Formation. The volcanic rocks and related sedimentary rocks cap Grand Mesa; the Eocene and Cretaceous sedimentary rocks crop out on the flanks of Grand Mesa and on the summit and flanks of Battlement Mesa.

The major rock types in the Uncompahgre National Forest (fig. 3) are, from youngest to oldest: 1, Pliocene and Miocene basalt flows and associated tuff, breccia, and conglomerate; 2, Oligocene ash-flow tuff; 3, Oligocene inter-ash-flow quartz latitic lava and breccia; 4, Oligocene andesitic lava and breccia; 5, sandstone, shale, claystone, and conglomerate of the Cretaceous Mancos Shale Formation and Dakota Sandstone; 6, claystone, sandstone, mudstone, shale, siltstone, and limestone of the Jurassic Morrison and Summerville Formations and Entrada Sandstone; 7, sandstone, siltstone, and conglomerate of the Triassic Wingate, Chinle and Dolores Formations; 8, arkosic sandstone, siltstone, and conglomerate of Permian Cutler Formation; 9, arkosic sandstone, conglomerate, shale, and limestone of Pennsylvanian Hermosa Formation; 10, limestone, dolomite, arkosic sandstone, conglomerate, and shale of Mississippian Leadville Limestone, Devonian Ouray Limestone, and Devonian Elbert Formation; and 11, Tertiary granodiorite, quartz monzonite, and granite and Proterozoic granite.

The major rock types in the Gunnison National Forest (fig. 4) are, from youngest to oldest: 1, Pliocene and Miocene basalt 


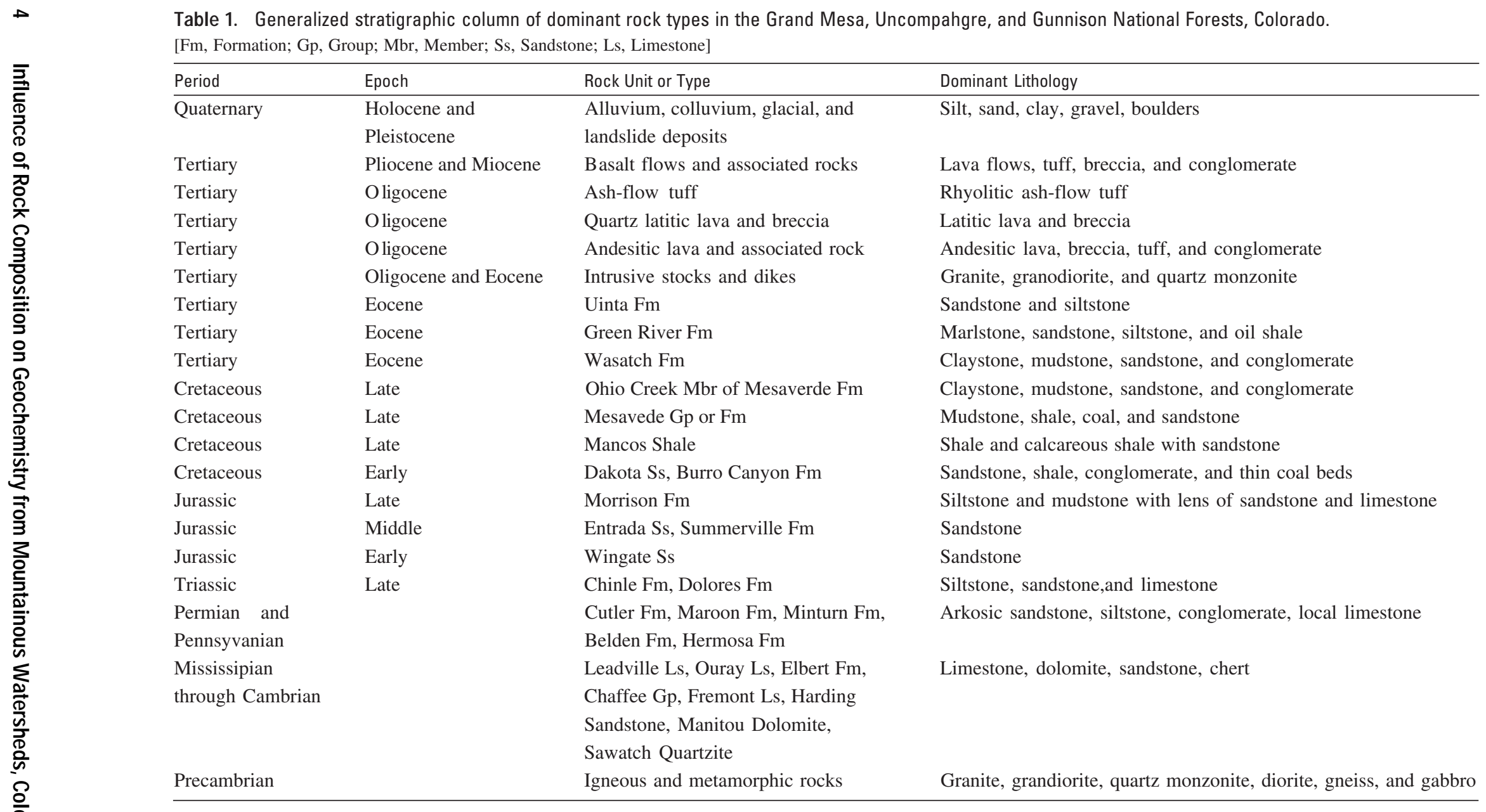




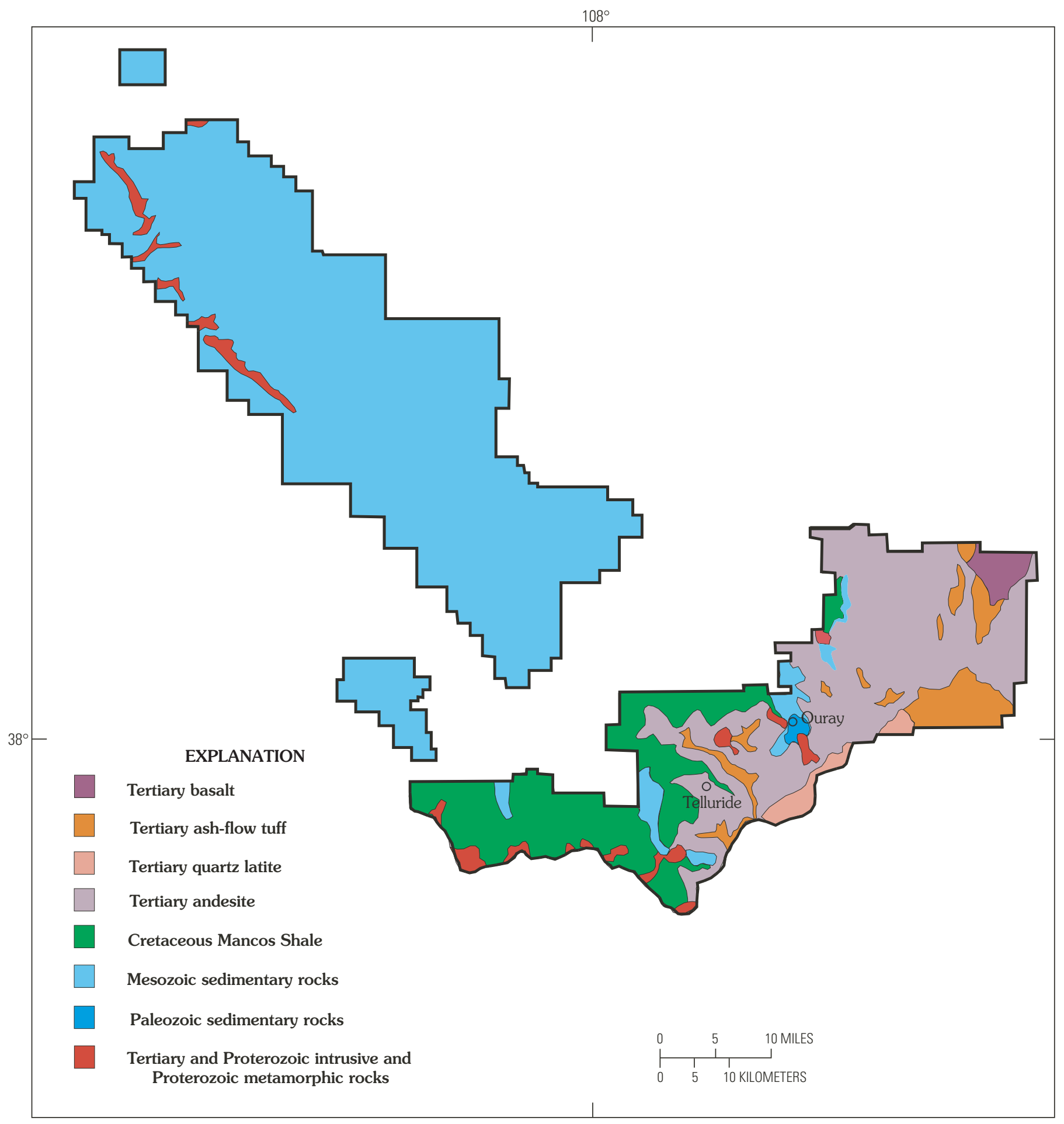

Figure 3. Generalized geologic map of the Uncompahgre National Forest, Colorado. Modified from Tweto (1979).

flows and associated tuff, breccia, and conglomerate; 2, Oligocene ash-flow tuff; 3 , Oligocene inter-ash-flow quartz latitic lava and breccia; 4, Oligocene andesitic lava and breccia; 5, sandstone and shale of the Oligocene Duchesne River Formation; 6 , claystone, mudstone, sandstone, and conglomerate of the Eocene Wasatch Formation and Upper Cretaceous Ohio Creek Member of Mesaverde Formation; 7, sandstone and shale with coal beds of the Cretaceous Mesaverde Formation; 8, sandstone, shale, and conglomerate of the Cretaceous Mancos Shale; 9 , arkosic sandstone, siltstone, conglomerate, and limestone of the Permian and Pennsylvanian Maroon Formation; 10, arkosic sandstone, shale, conglomerate, and limestone of the Pennsylvanian Minturn and Belden Formations; 11, limestone, dolomite, arkosic sandstone, shale, limestone, dolomite, arkosic sandstone, conglomerate and conglomerate of the Mississippian Leadville Limestone, Mississippian and Devonian Chaffee Group, Ordovician Fremont Limestone, Ordovician Harding Sandstone and Ordovician Manitou Limestone, and Cambrian 


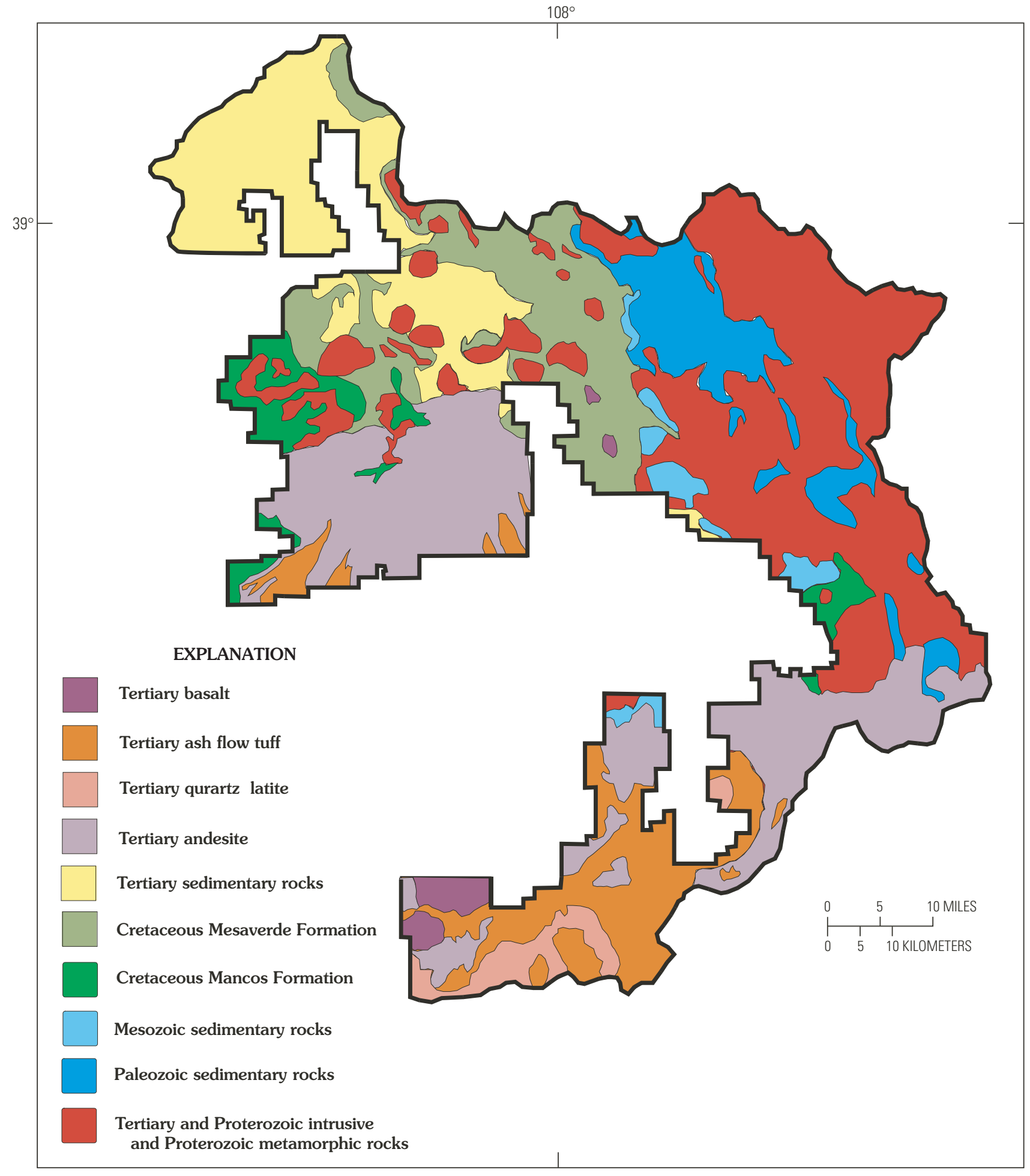

Figure 4. Generalized geologic map of the Gunnison National Forest, Colorado. Modified from Tweto (1979).

Sawatch Quartzite and Peerless Formation; and 12, Tertiary granodiorite, quartz monzonite, and granite and Proterozoic granite, granodiorite, quartz monzonite, diorites, gneiss, and gabbro.

The major rock types in the three national forests are divided into ten dominant rock composition types. Some of the composition types are represented by a single formation such as the Mesavede Formation. Others are represented by rocks of different ages, such as Cretaceous, Jurassic, and Triassic sedimentary rocks of similar composition. In some cases, the designation of a rock composition type such as felsic ash-flow tuff, adesitic lavas and breccia, and basalts flows and associated rocks is straightforward. In other cases, such as the Mancos Shale type and the Mesaverde Formation type, the rock type is predominantly a single lithology. In other cases, such as Tertiary, Mesozoic, and Paleozoic sedimentary rocks, the composition type is selected partly for practical reasons. Some water in 
Table 2. The ten dominant rock compositon types in the Grand Mesa, Uncompahgre, and Gunnison National Forests, Colorado.

\begin{tabular}{lll}
\hline Age & Rock Composition Type & Setting \\
\hline Tertiary & Basalt flows and associated rocks & Grand Mesa \\
Tertiary & Felsic ash-flow tuff & San Juan volcanic field \\
Tertiary & Quartz latitic lava and breccia & San Juan volcanic field \\
Tertiary & Andesitic lava and breccia & West Elk volcanic field \\
Tertiary & Sedimentary rocks: shale, oil shale, sandstone, marlstone, & Battlement and Grand Mesa \\
Cretaceous & Mesaystone, and lignite & Piceance Basin, Elk Mountains \\
Cretaceous & Mancos Shale: marine shale, sandstone, and calcareous & San Juan volcanic field, Paradox Basin \\
Mesozoic & sandstone & Uncompahgre uplift \\
Paleozoic & Sedimentary rocks: sandstone, siltstone, shale, limestone, & West flank of Sawatch Range \\
conglomerate, and mudstone & Sedimentary rocks: sandstone, conglomerate, & Sawatch Range; scattered \\
Proterozoic & carbonate, quartzite, shale, mudstone,and grit & throughout remaining area \\
\hline
\end{tabular}

areas underlain by composition types of small aerial extent would be difficult or impossible to sample. Also, the rock types must represent major spatial distributions of rock composition types. It would not be practical to sample a rock type that comprises only 1 percent of the total distribution of the rock types in the three national forests.

The dominant rock types selected (table 2 ) are 1 , Tertiary basalt flows and associated rocks; 2 , Tertiary felsic ash-flow tuff; 3 , Tertiary quartz latitic lava and breccia; 4 , Tertiary andesitic lavas and associated rocks; 5, Tertiary sedimentary rocks; 6, Cretaceous Mesavede Formation; 7, Cretaceous Mancos Shale; 8, Mesozoic sedimentary rocks consisting of Cretaceous, Jurassic, and Triassic sedimentary rocks that are predominantly sandstone; 9, Paleozoic sedimentary rocks; and 10, Tertiary granodiorite, quartz monzonite, and granite and Proterozoic granite, granodiorite, quartz monzonite, diorites, gabbro, and gneiss. The ten dominant rock composition types represent more than 95 percent of the rocks at the surface in the three national forests.

\section{Methods}

Generally, small streams were sampled. Usually the streams had watershed areas of several square miles, although some watersheds were larger. Springs within a watershed also were sampled. The sample sites were selected to provide coverage to each of the ten major rock composition types within the three national forests.

Samples of water were collected from stream and spring sites in the study area during July and August of 1998 and during August of 1999. The samples were collected after runoff had occurred but prior to the streams reaching base flow. Samples from areas underlain by each major rock composition type usually were collected during an interval of one or two days. Samples from lower elevations were collected earlier in the season than were those in high alpine areas. During sampling, the weather was stable and no precipitation occurred. Samples were collected by width and depth integration (Edwards and Glysson, 1988) or, for springs from a point source. Temperature, $\mathrm{pH}$, and conductivity were measured at each site. An Orion model $250 \mathrm{pH}$ meter was used with an Orion Ross Sure-Flow electrode. Conductivity was measured using an Orion model 120 conductivity meter. Samples were collected in high-density polyethylene bottles. For dissolved cation analyses, a sample was filtered at the site through a $0.45 \mu \mathrm{m}$-membrane filter and acidified with ultrapure reagent-grade Ultrex nitric acid to $\mathrm{pH}$ $<2$. Another sample was filtered, but not acidified, for anion analyses, and an unfiltered, unacidified sample was collected for alkalinity measurement. The samples initially were stored in an ice chest and later in a refrigerator; they were kept cool until analyzed in the laboratory.

In the laboratory, alkalinity, as $\mathrm{HCO}_{3}{ }^{-}$, was determined by titration with $\mathrm{H}_{2} \mathrm{SO}_{4}$ using Gran's plot technique (Orion Research, Incorporated, 1978). Sulfate, chloride, nitrate, and fluoride concentrations were determined by ion chromatography (IC) (Fishman and Pyen, 1979). Cations were analyzed by inductively coupled plasma-atomic emission spectromentry (ICP-AES) or inductively coupled plasma-mass spectromentry (ICP-MS). IC and alkalinity analyses were performed by Murdock Environmental Laboratory, University of Montana, Missoula, Montana. The ICP-MS analyses for samples collected in 1998 were determined by ACTLABS, Wheat Ridge, Colorado. The samples collected in 1999 were determined by USGS laboratory, under the direction of Paul Lamothe. The ICP-AES analyses for samples collected in 1998 were determined by Murdock Environmental Laboratory. The samples collected in 1999 were determined by USGS laboratory, under the direction of Paul Briggs. Duplicate water samples, blank samples, and USGS Water Resource Division standard reference waters were analyzed with each data set. The chemical analyses are in appendix 1. 


\section{Results}

Water samples were collected from small streams or springs in watersheds that were in or mainly in the three national forests. The watersheds are mountainous headwaters that were not impacted by historic mining. Grazing of cattle in some of the watersheds possibly affects the water quality. The sample sites were selected so that, as closely as possible, the geochemical baseline chemistry approximates the natural background geochemistry for each of the ten rock composition types (table 2) that are dominant in the three national forests. The ranges and means of chemical species and other parameters were determined for water from areas that are underlain by each of the dominant rock composition types. The means of chemical species in water of the ten rock composition types can be compared to average fresh water (table 3 ).

\section{Tertiary Basalt Flow s and Associated Rocks}

Water samples were collected from four small streams in areas underlain by Pliocene and Miocene basaltic lava, tuff, breccia, and conglomerate on the summit of Grand Mesa in the Grand Mesa National Forest (fig. 5). The ranges and means of selected chemical species in the waters are listed in table 4. The chemical analyses of samples from these sites and other sites are in appendix 1. The summit of Grand Mesa is more than a mile higher than the surrounding valley floors. The basaltic rocks that cap the mesa overlie the Tertiary Green River and Wasatch Formations and the Cretaceous Ohio Creek Member of the Mesaverde Formation. The relief on the surface of Grand Mesa is low. The area receives 30 to 45 in. of annual precipitation (Colorado Climate Center, 1984), and snow pack ranges from 5 to 10 feet each year. The vegetation is mainly sub-alpine forest and grassland.

The water samples are dilute $\mathrm{Ca}^{2+}-\mathrm{HCO}_{3}{ }^{-}$type water with slightly alkaline $\mathrm{pH}$ values and moderate to low alkalinity values. The mean $\mathrm{pH}$ is 7.41 and mean conductivity is $63 \mu \mathrm{S} / \mathrm{cm}$. The mean $\mathrm{Cl}$ concentration is $0.29 \mathrm{mg} / \mathrm{L}$, indicating that much of the water is snow melt with minimal duration of contact with the rocks. The $\mathrm{Cl}$ does not normally react and precipitate with other species until highly concentrated; therefore it is a good indicator of evaporation effects. All specie concentrations are low, except for Al. The mean Al concentration is $54 \mu \mathrm{g} / \mathrm{L}$, probably because the initial low $\mathrm{pH}$ values of the melting snow are favorable for mobility of Al. Generally, water in contact with basaltic rocks is well buffered, with moderate values of alkalinity. Because of the short duration of contact of melting snow with the basaltic rocks on Grand Mesa, the water has moderately low alkalinity values. The alkalinity ranges from 24 to $30 \mathrm{mg} / \mathrm{L}$ as $\mathrm{HCO}_{3}{ }^{-}$, with a mean of $28 \mathrm{mg} / \mathrm{L}$. This low mean value indicates that the summit of Grand Mesa is moderately susceptible to introduced acidification. Introduced acidity from sources such as acid rain in the future possibly could neutralize the alkalinity in water, causing the streams and lakes on Grand Mesa to become acidic. Except for moderate amounts of $\mathrm{Al}$, the water from Grand Mesa is excellent in water quality.
Table 3. Background of trace metals in fresh water and chemical analyses of mean river water.

\begin{tabular}{|c|c|}
\hline \multicolumn{2}{|c|}{ Background of trace metals (in $\mu \mathrm{g} / \mathrm{L}$ ) in fresh water } \\
\hline Element & $\begin{array}{c}\text { Data from } \\
\text { Forstner and Wittmann (1979) }\end{array}$ \\
\hline Al & $<30$ \\
\hline $\mathrm{Fe}$ & $<30$ \\
\hline $\mathrm{Mn}$ & $<5$ \\
\hline $\mathrm{Cu}$ & 1.8 \\
\hline $\mathrm{Zn}$ & 10 \\
\hline As & 2 \\
\hline Mo & 1 \\
\hline $\mathrm{Pb}$ & 0.2 \\
\hline $\mathrm{Sb}$ & 0.1 \\
\hline $\mathrm{Cd}$ & 0.07 \\
\hline $\mathrm{Cr}$ & 0.5 \\
\hline $\mathrm{Ni}$ & 0.3 \\
\hline Co & 0.05 \\
\hline $\mathrm{V}$ & 0.9 \\
\hline $\mathrm{Ba}$ & 10 \\
\hline $\mathrm{Be}$ & 0.01 \\
\hline $\mathrm{Li}$ & 1 \\
\hline $\mathrm{Se}$ & 0.1 \\
\hline $\mathrm{Sr}$ & 50 \\
\hline $\mathrm{U}$ & 0.5 \\
\hline \multicolumn{2}{|c|}{ Chemical analyses (in $\mathrm{mg} / \mathrm{L}$ ) of mean river water } \\
\hline Element & Data from Livingstone (1963) \\
\hline $\mathrm{Ca}$ & 15 \\
\hline $\mathrm{Mg}$ & 4.1 \\
\hline $\mathrm{Na}$ & 6.3 \\
\hline $\mathrm{K}$ & 2.3 \\
\hline $\mathrm{SiO}_{2}$ & 13.1 \\
\hline $\mathrm{SO}_{4}^{2-}$ & 11.2 \\
\hline $\mathrm{HCO}_{3}^{-}$ & 58.4 \\
\hline $\mathrm{Cl}^{-}$ & 7.8 \\
\hline
\end{tabular}

\section{Tertiary Ash-Flow Tuff}

Water samples were collected from three streams and two springs in the Los Pinos Creek and Pauline Creek watersheds, in the Gunnison National Forest in areas underlain by Oligocene rhyolitic ash-flow tuff (fig. 6). The source of the tuff is calderas in the San Juan Mountains to the south. The relief in the area is high, and the dominant vegetation is subalpine forest. Annual precipitation ranges from 16 to 30 in. (Colorado Climate Center, 1984). The ranges and means of selected chemical species in the water are listed in table 5. The water samples are $\mathrm{Ca}^{2+}$ $\mathrm{HCO}_{3}{ }^{-}$type water with slightly acidic to slightly alkaline $\mathrm{pH}$ values and moderately low conductivity values. The mean $\mathrm{pH}$ is 7.43 and the mean conductivity is $100 \mu \mathrm{S} / \mathrm{cm}$. The mean $\mathrm{Zn}$ and $\mathrm{Cu}$ concentrations are very low, at $0.24 \mu \mathrm{g} / \mathrm{L}$ and $<0.1 \mu \mathrm{g} / \mathrm{L}$, respectively. The $\mathrm{SiO}_{2}$ concentrations ranged from 19 to $41 \mathrm{mg}$ / $\mathrm{L}$ with a mean of $29 \mu \mathrm{g} / \mathrm{L}$. The higher concentrations of $\mathrm{SiO}_{2}$ probably are caused by the felsic composition of the bedrock; because of the fine grain size of the minerals that compose the rock, the felsic rocks are particularly susceptible to silicate 


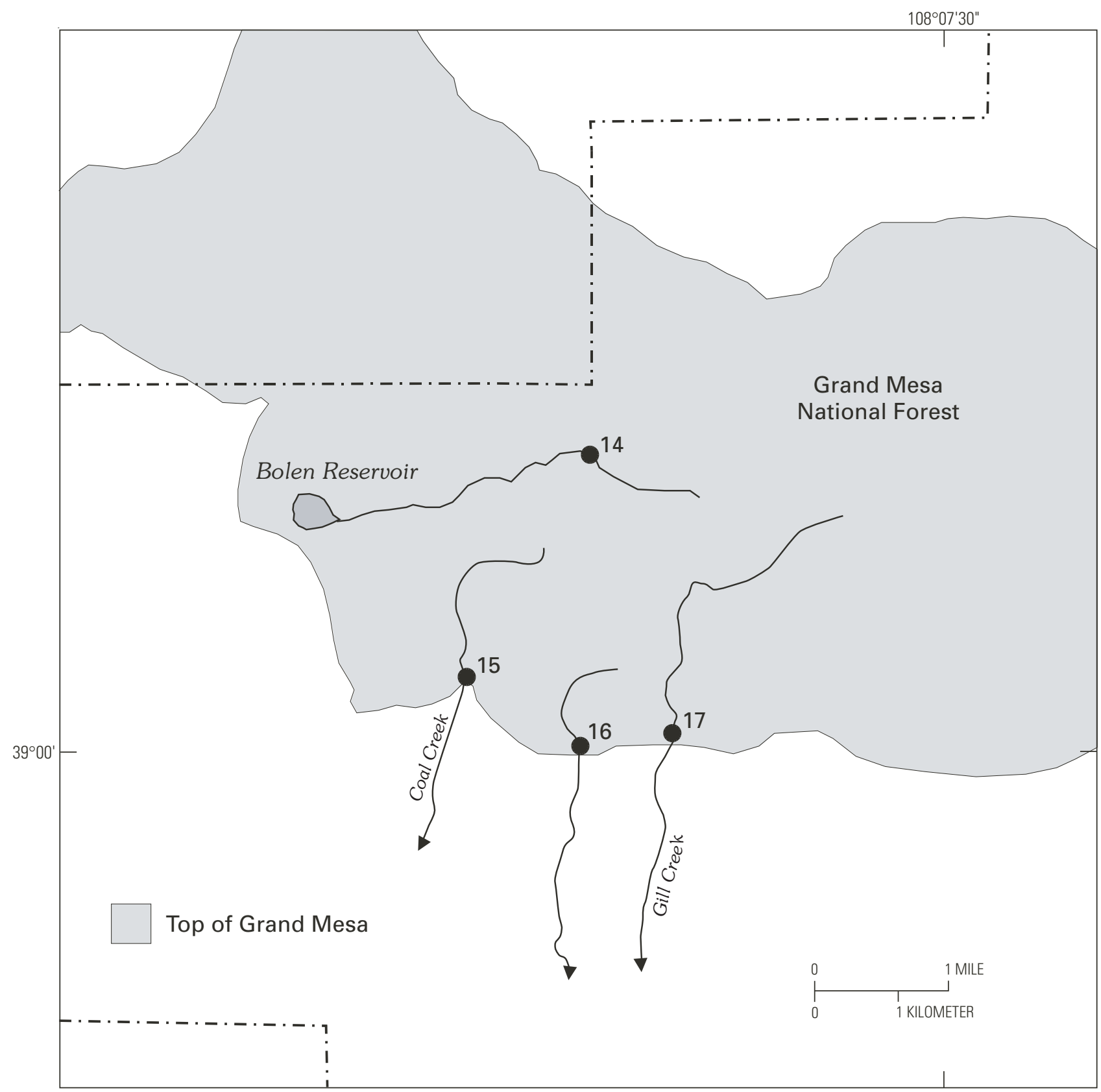

Figure 5. Site localities of stream water samples from areas underlain by Tertiary basalt flows and associated rocks, Grand Mesa National Forest (patterned), Colorado.

dissolution. The alkalinity values ranged from 32 to $70 \mathrm{mg} / \mathrm{L}$ as $\mathrm{HCO}_{3}{ }^{-}$, with a mean of $46 \mathrm{mg} / \mathrm{L}$. This moderately low value reflects the fact that felsic rocks do not weather as rapidly as do more mafic rocks. The mean $\mathrm{Cl}$ content is $0.88 \mathrm{mg} / \mathrm{L}$, which is low; it reflects the short residence time of the melting snow and storm runoff in contact with the rocks and also a lack of significant evaporation. The Fe concentrations in two stream samples were high, with 255 and $640 \mu \mathrm{g} / \mathrm{L}$ (app. 1). Both sites were contaminated by cattle waste, and the samples were yellowish brown in color. The wastes probably cause more reducing conditions, which favor mobility of Fe. It is also possible that the Fe mobility is caused by Fe complexing with organic matter. Other water samples from watersheds underlain by the Tertiary ash-flow tuff are of good chemical quality. The felsic rock type and the short duration of contact of the water and rock both favor moderately low alkalinity. Because of the moderately low alkalinity, the area is moderately susceptible to introduced acidification. Moderate acidification from mining or atmospheric precipitation in the future possibly could neutralize alkalinity and cause the stream waters to become acidic.

\section{Tertiary Quartz Latitic Lava and Breccia}

Water samples were collected from four streams in the Mineral Creek drainage in the northern part of the San Juan volcanic field in the La Garita Wilderness, Gunnison National Forest (fig. 7). The area is underlain by Oligocene inter-ash-flow 
Table 4. Summary of the chemistry of four stream water samples from watersheds underlain by Tertiary basalt flows and associated rocks, Grand Mesa National Forest, Colorado.

\begin{tabular}{|c|c|c|c|}
\hline \multirow[t]{2}{*}{ Measurement ${ }^{1}$} & \multicolumn{2}{|c|}{ Range } & \multirow[t]{2}{*}{ Mean² } \\
\hline & Minimum & Maximum & \\
\hline Conductivity & 59 & 66 & 63 \\
\hline $\mathrm{pH}$ & 7.09 & 7.67 & 7.41 \\
\hline $\mathrm{Ca}$ & 4 & 6.1 & 5.4 \\
\hline $\mathrm{Mg}$ & 1.8 & 2.3 & 2.1 \\
\hline $\mathrm{Na}$ & 1.5 & 2 & 1.8 \\
\hline $\mathrm{K}$ & 0.24 & 0.45 & 0.37 \\
\hline $\mathrm{SiO}_{2}$ & 11 & 19 & 14 \\
\hline Alkalinity & 24 & 30 & 28 \\
\hline $\mathrm{SO}_{4}$ & 0.38 & 1.6 & 0.65 \\
\hline $\mathrm{Cl}$ & $<0.25$ & 0.6 & 0.29 \\
\hline $\mathrm{F}$ & $<0.1$ & $<0.1$ & $<0.1$ \\
\hline $\mathrm{Al}$ & 38 & 107 & 54 \\
\hline $\mathrm{Fe}$ & 44 & 151 & 91 \\
\hline $\mathrm{Mn}$ & 4.2 & 27 & 15 \\
\hline $\mathrm{Cu}$ & $<1$ & $<1$ & $<1$ \\
\hline $\mathrm{Zn}$ & 0.32 & 0.52 & 0.4 \\
\hline $\mathrm{Pb}$ & $<0.1$ & 1.4 & 0.15 \\
\hline Mo & $<0.5$ & 0.53 & $<0.5$ \\
\hline $\mathrm{Sb}$ & $<0.01$ & 0.22 & 0.017 \\
\hline As & $<0.03$ & 0.67 & 0.048 \\
\hline Th & 0.069 & 0.1 & 0.083 \\
\hline $\mathrm{U}$ & 0.036 & 0.15 & 0.069 \\
\hline $\mathrm{Li}$ & $<0.5$ & $<0.5$ & $<0.5$ \\
\hline $\mathrm{Ba}$ & 10 & 17 & 14 \\
\hline $\mathrm{Sr}$ & 29 & 39 & 36 \\
\hline $\mathrm{V}$ & $<0.5$ & 0.57 & $<0.5$ \\
\hline $\mathrm{Sc}$ & 17 & 26 & 21 \\
\hline $\mathrm{Rb}$ & 0.29 & 1.3 & 0.5 \\
\hline $\mathrm{Y}$ & 0.31 & 0.53 & 0.41 \\
\hline $\mathrm{Zr}$ & 0.28 & 1 & 0.43 \\
\hline $\mathrm{La}$ & 0.17 & 0.31 & 0.25 \\
\hline $\mathrm{Br}$ & $<3$ & $<3$ & $<3$ \\
\hline I & $<0.2$ & 20 & 0.98 \\
\hline
\end{tabular}

${ }^{1}$ Conductivity in $\mu \mathrm{S} / \mathrm{cm}$; $\mathrm{Ca}, \mathrm{Mg}, \mathrm{Na}, \mathrm{K}, \mathrm{SiO}_{2}, \mathrm{SO}_{4}, \mathrm{Cl}$, and $\mathrm{F}$ in $\mathrm{mg} / \mathrm{L}$; alkalinity in $\mathrm{mg} / \mathrm{L} \mathrm{HCO}_{3}{ }^{-}$; remaining elements in $\mu \mathrm{g} / \mathrm{L}$

${ }^{2} \mathrm{All}$ variables are geometric means except for $\mathrm{pH}$, which is arithmetic mean

quartz latitic lava and breccia (Tweto, 1976). The relief is high and the dominant vegetation is subalpine forest. The annual precipitation ranges from 16 to 25 in. (Colorado Climate Center, 1984). The ranges and means of selected chemical species in the water samples are listed in table 6 . The sites produced three $\mathrm{Ca}^{2+}-\mathrm{HCO}_{3}{ }^{-}$type samples and one $\mathrm{Na}^{+}-\mathrm{HCO}_{3}^{-}$type sample with slightly alkaline $\mathrm{pH}$ values and moderately low conductivity values. The mean $\mathrm{pH}$ is 7.48 and mean conductivity is 124 $\mu \mathrm{S} / \mathrm{cm}$. Trace metal concentrations are low. The mean $\mathrm{Zn}, \mathrm{Cu}$, $\mathrm{Mo}$, and As concentrations are 0.5, 0.56, 0.54, and $<3 \mu \mathrm{g} / \mathrm{L}$, respectively. The range of $\mathrm{SiO}_{2}$ concentrations is 20 to $56 \mathrm{mg} /$
Table 5. Summary of the chemistry of three stream water samples and two spring water samples from watersheds underlain by Tertiary felsic ash-flow tuff, Gunnison National Forest, Colorado.

\begin{tabular}{|c|c|c|c|}
\hline \multirow[t]{2}{*}{ Measurement ${ }^{1}$} & \multicolumn{2}{|c|}{ Range } & \multirow[t]{2}{*}{ Mean $^{2}$} \\
\hline & Minimum & Maximum & \\
\hline Conductivity & 57 & 139 & 100 \\
\hline pH & 6.89 & 8.02 & 7.43 \\
\hline $\mathrm{Ca}$ & 5.3 & 16.5 & 11 \\
\hline $\mathrm{Mg}$ & 0.83 & 2.8 & 1.7 \\
\hline $\mathrm{Na}$ & 3.1 & 7.9 & 4.4 \\
\hline K & 0.87 & 2.3 & 1.3 \\
\hline $\mathrm{SiO}_{2}$ & 19 & 41 & 29 \\
\hline Alkalinity & 32 & 70 & 46 \\
\hline $\mathrm{SO}_{4}$ & 1.4 & 6 & 2.7 \\
\hline $\mathrm{Cl}$ & 0.37 & 1.9 & 0.88 \\
\hline $\mathrm{F}$ & $<0.1$ & 0.14 & 0.1 \\
\hline $\mathrm{Al}$ & 6.7 & 34 & 16 \\
\hline $\mathrm{Fe}$ & 9.5 & 640 & 65 \\
\hline $\mathrm{Mn}$ & $<0.3$ & 32 & 2.9 \\
\hline $\mathrm{Cu}$ & $<1$ & $<1$ & $<1$ \\
\hline $\mathrm{Zn}$ & $<0.2$ & 0.32 & 0.24 \\
\hline $\mathrm{Pb}$ & $<0.1$ & 1.1 & 0.12 \\
\hline Mo & $<0.5$ & 0.6 & $<0.5$ \\
\hline $\mathrm{Sb}$ & $<0.01$ & 0.13 & 0.021 \\
\hline As & 0.79 & 2.2 & 1.2 \\
\hline Th & 0.07 & 0.57 & 0.19 \\
\hline $\mathrm{U}$ & 0.012 & 0.2 & 0.058 \\
\hline $\mathrm{Li}$ & 0.86 & 2.8 & 1.5 \\
\hline $\mathrm{Ba}$ & 10 & 32 & 18 \\
\hline $\mathrm{Sr}$ & 47 & 109 & 79 \\
\hline $\mathrm{V}$ & $<0.5$ & 3.4 & 1.2 \\
\hline $\mathrm{Sc}$ & 22 & 51 & 35 \\
\hline $\mathrm{Rb}$ & 0.3 & 3.1 & 1.2 \\
\hline $\mathrm{Y}$ & 0.047 & 0.18 & 0.1 \\
\hline $\mathrm{Zr}$ & 0.12 & 19 & 0.51 \\
\hline $\mathrm{La}$ & $<0.005$ & 0.17 & 0.024 \\
\hline $\mathrm{Br}$ & $<3$ & 33 & 3.5 \\
\hline I & $<0.2$ & 7.8 & 2.2 \\
\hline
\end{tabular}

${ }^{1}$ Conductivity in $\mu \mathrm{S} / \mathrm{cm}$; $\mathrm{Ca}, \mathrm{Mg}, \mathrm{Na}, \mathrm{K}, \mathrm{SiO}_{2}, \mathrm{SO}_{4}, \mathrm{Cl}$, and $\mathrm{F}$ in $\mathrm{mg} / \mathrm{L}$; alkalinity in $\mathrm{mg} / \mathrm{L} \mathrm{HCO}_{3}{ }^{-}$; remaining elements in $\mu \mathrm{g} / \mathrm{L}$

${ }^{2} \mathrm{All}$ variables are geometric means except for $\mathrm{pH}$, which is arithmetic mean

$\mathrm{L}$, with a mean of $31 \mathrm{mg} / \mathrm{L}$. The higher values probably are caused by the felsic composition of the rocks and by the fine grain size of the rock minerals with high surface areas available for chemical reactions, which favor chemical dissolution of the silicates. The mean concentrations of $\mathrm{Al}$ and $\mathrm{Fe}$ are moderately high, 60 and $55 \mu \mathrm{g} / \mathrm{L}$, respectively. The concentration of $\mathrm{Mn}$ is low, with a mean of $2.7 \mu \mathrm{g} / \mathrm{L}$. The low mean $\mathrm{Cl}$ concentration, $0.56 \mathrm{mg} / \mathrm{L}$, reflects the short residence time of the water from melting snow and rain in contact with the rocks and also the lack of significant evaporation. The alkalinity as $\mathrm{HCO}_{3}{ }^{-}$ranged from 29 to $44 \mathrm{mg} / \mathrm{L}$, with a mean of $36 \mathrm{mg} / \mathrm{L}$, indicating weak acid-neutralizing capacity. The felsic rock lithology and the short duration of time of the water and rock favor moderately low alkalinity values. Because of the moderately low alkalinity values, the areas underlain by quartz latitic rocks are 


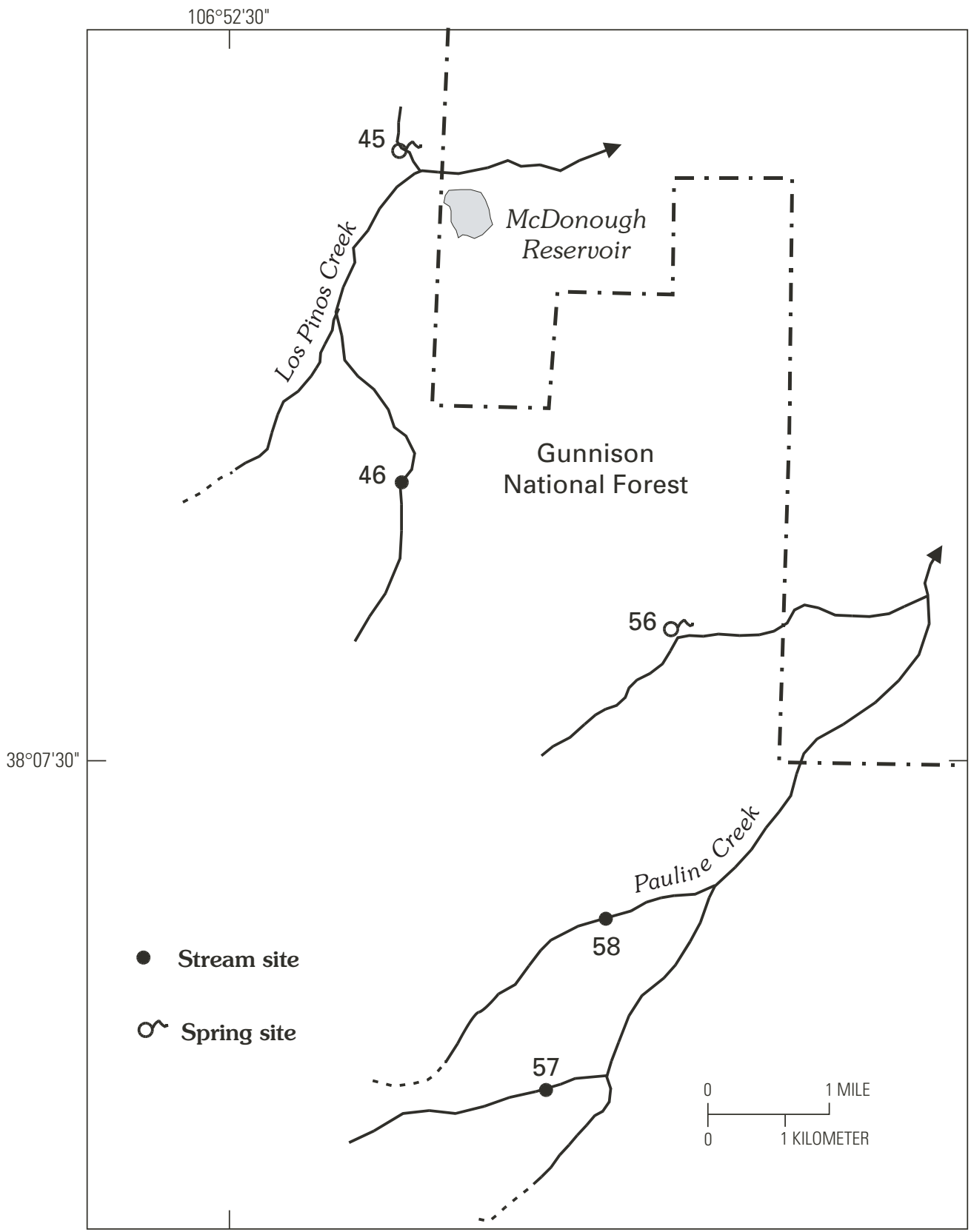

Figure 6. Site localities of stream and spring water samples from areas underlain by Tertiary ash-flow tuff in Los Pinos and Pauline Creek watersheds, Gunnison National Forest, Colorado.

moderately susceptible to introduced acidification. Moderate acidification in the future possibly could neutralize the alkalinity and cause the stream waters to become acidic. The chemical quality of the waters from watersheds underlain by Tertiary quartz latitic rocks is good.

\section{Tertiary Andesitic Lava and B reccia}

Water samples were collected from eight streams in the Soap Creek area of the West Elk Mountains, Gunnison National Forest (fig. 8). The area is underlain by Oligocene andesitic lava flows, breccia, tuff, and conglomerate. The andesitic rocks originated from the nearby West Elk volcanic centers (Hansen,
1965; Gaskill and others, 1981). The relief is high and the dominant vegetation is subalpine forest. The annual precipitation ranges from 20 to $40 \mathrm{in}$. (Colorado Climate Center, 1984). The ranges and means of selected chemical species in the samples are listed in table 7. The samples are $\mathrm{Ca}^{2+}-\mathrm{HCO}_{3}{ }^{-}$type water with alkaline $\mathrm{pH}$ values and moderate conductivity values. The mean $\mathrm{pH}$ is 7.99 and the mean conductivity is $158 \mu \mathrm{S} / \mathrm{cm}$. The trace element concentrations are low to very low. The mean $\mathrm{Zn}$, $\mathrm{Cu}, \mathrm{Mo}$, and As concentrations are $0.22 \mu \mathrm{g} / \mathrm{L},<1 \mu \mathrm{g} / \mathrm{L},<0.5 \mu \mathrm{g} /$ $\mathrm{L}$, and $0.7 \mu \mathrm{g} / \mathrm{L}$, respectively. The range of $\mathrm{SiO}_{2}$ concentrations is 22 to $48 \mathrm{mg} / \mathrm{L}$, with a mean of $35 \mathrm{mg} / \mathrm{L}$. The higher values probably are caused by the fine grain size of the rock minerals with high surface areas available for chemical reactions, which favors dissolution of silicates. The mean concentrations of Al, 


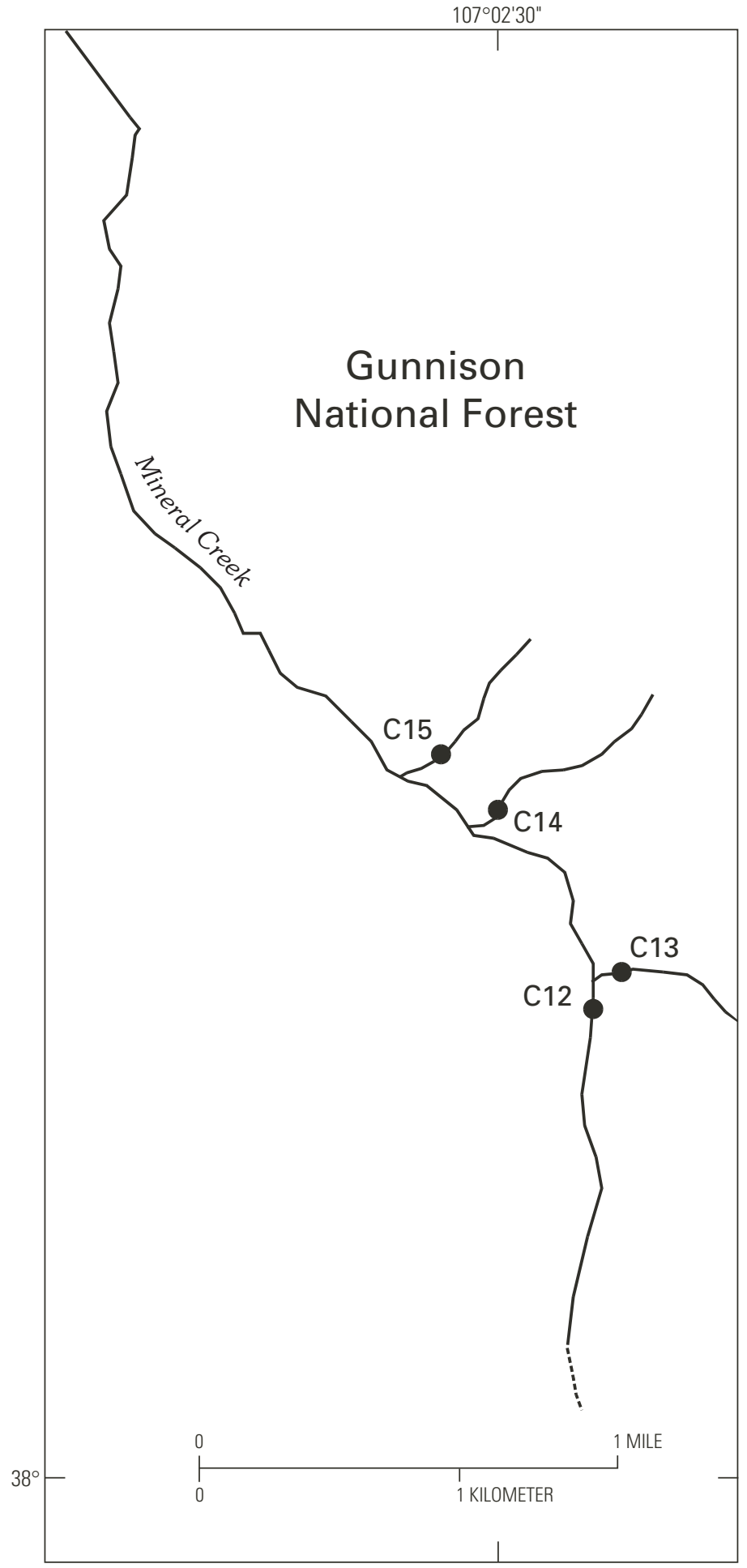

Figure 7. Site localities of stream water samples from areas underlain by Tertiary quartz latitic lava and breccia in the Mineral Creek watershed, Gunnison National Forest, Colorado.

$\mathrm{Fe}$, and $\mathrm{Mn}$ are moderately low, 13,16 , and $0.48 \mu \mathrm{g} / \mathrm{L}$, respectively. The low mean $\mathrm{Cl}$ concentration, $0.7 \mathrm{mg} / \mathrm{L}$, reflects the short residence time of the water from melting snow and storm runoff in contact with the rocks and also the lack of significant evaporation. The alkalinity as $\mathrm{HCO}_{3}{ }^{-}$ranges from 32 to $102 \mathrm{mg} /$
Table 6. Summary of the chemistry of four stream water samples from watersheds underlain by Tertiary quartz latitic lava and breccia, Gunnison National Forest, Colorado.

\begin{tabular}{|c|c|c|c|}
\hline \multirow[t]{2}{*}{ Measurement ${ }^{1}$} & \multicolumn{2}{|c|}{ Range } & \multirow[t]{2}{*}{ Mean ${ }^{2}$} \\
\hline & Minimum & Maximum & \\
\hline Conductivity & 108 & 140 & 124 \\
\hline $\mathrm{pH}$ & 7.35 & 7.75 & 7.48 \\
\hline $\mathrm{Ca}$ & 8.7 & 16 & 12.6 \\
\hline $\mathrm{Mg}$ & 0.78 & 2.9 & 1.8 \\
\hline $\mathrm{Na}$ & 3.7 & 13 & 6.9 \\
\hline K & 0.69 & 2.2 & 1.1 \\
\hline $\mathrm{SiO}_{2}$ & 20 & 56 & 30.8 \\
\hline Alkalinity & 29 & 44 & 36 \\
\hline $\mathrm{SO}_{4}$ & 10 & 28 & 16.6 \\
\hline $\mathrm{Cl}$ & $<0.25$ & 1.5 & 0.56 \\
\hline $\mathrm{F}$ & $<0.1$ & $<0.1$ & $<0.1$ \\
\hline $\mathrm{Al}$ & 7.9 & 356 & 55 \\
\hline $\mathrm{Fe}$ & 33 & 159 & 60 \\
\hline Mn & 1 & 21 & 2.7 \\
\hline $\mathrm{Cu}$ & $<0.5$ & 0.8 & 0.56 \\
\hline $\mathrm{Zn}$ & $<0.5$ & 1 & 0.5 \\
\hline $\mathrm{Pb}$ & $<0.05$ & $<0.05$ & $<0.05$ \\
\hline Mo & 0.3 & 1 & 0.54 \\
\hline $\mathrm{Sb}$ & $<0.1$ & 0.2 & $<0.1$ \\
\hline As & $<3$ & $<3$ & $<3$ \\
\hline $\mathrm{Th}$ & $<0.005$ & 0.15 & 0.03 \\
\hline $\mathrm{U}$ & 0.08 & 0.32 & 0.14 \\
\hline $\mathrm{Li}$ & 1.7 & 10 & 3.6 \\
\hline $\mathrm{Ba}$ & 2.6 & 13 & 4.6 \\
\hline $\mathrm{Sr}$ & 58 & 171 & 115 \\
\hline $\mathrm{V}$ & 0.8 & 1.6 & 1.1 \\
\hline $\mathrm{Sc}$ & 1.9 & 5.3 & 2.9 \\
\hline $\mathrm{Rb}$ & 0.9 & 3 & 1.4 \\
\hline $\mathrm{Y}$ & 0.1 & 1.5 & 0.32 \\
\hline $\mathrm{Zr}$ & 0.08 & 1.4 & 0.32 \\
\hline $\mathrm{La}$ & 0.05 & 0.5 & 0.13 \\
\hline
\end{tabular}

${ }^{1}$ Conductivity in $\mu \mathrm{S} / \mathrm{cm}$; $\mathrm{Ca}, \mathrm{Mg}, \mathrm{Na}, \mathrm{K}, \mathrm{SiO}_{2}, \mathrm{SO}_{4}, \mathrm{Cl}$, and $\mathrm{F}$ in $\mathrm{mg} / \mathrm{L}$; alkalinity in $\mathrm{mg} / \mathrm{L} \mathrm{HCO}_{3}{ }^{-}$; remaining elements in $\mu \mathrm{g} / \mathrm{L}$

${ }^{2} \mathrm{All}$ variables are geometric means except for $\mathrm{pH}$, which is arithmetic mean

$\mathrm{L}$, with a mean of $72 \mathrm{mg} / \mathrm{L}$, indicating moderate acid-neutralizing capacity for introduced acidification. Although the residence time of water in contact with rock is short, the finegrained minerals and the intermediate composition of the rocks ensure that the rate of chemical weathering is rapid. Therefore, the water in this area underlain by Tertiary andesitic rocks, has moderate acid-neutralizing capacity for introduced acidification . The chemical quality of the water from watersheds underlain by Tertiary andesitic rocks is good. 


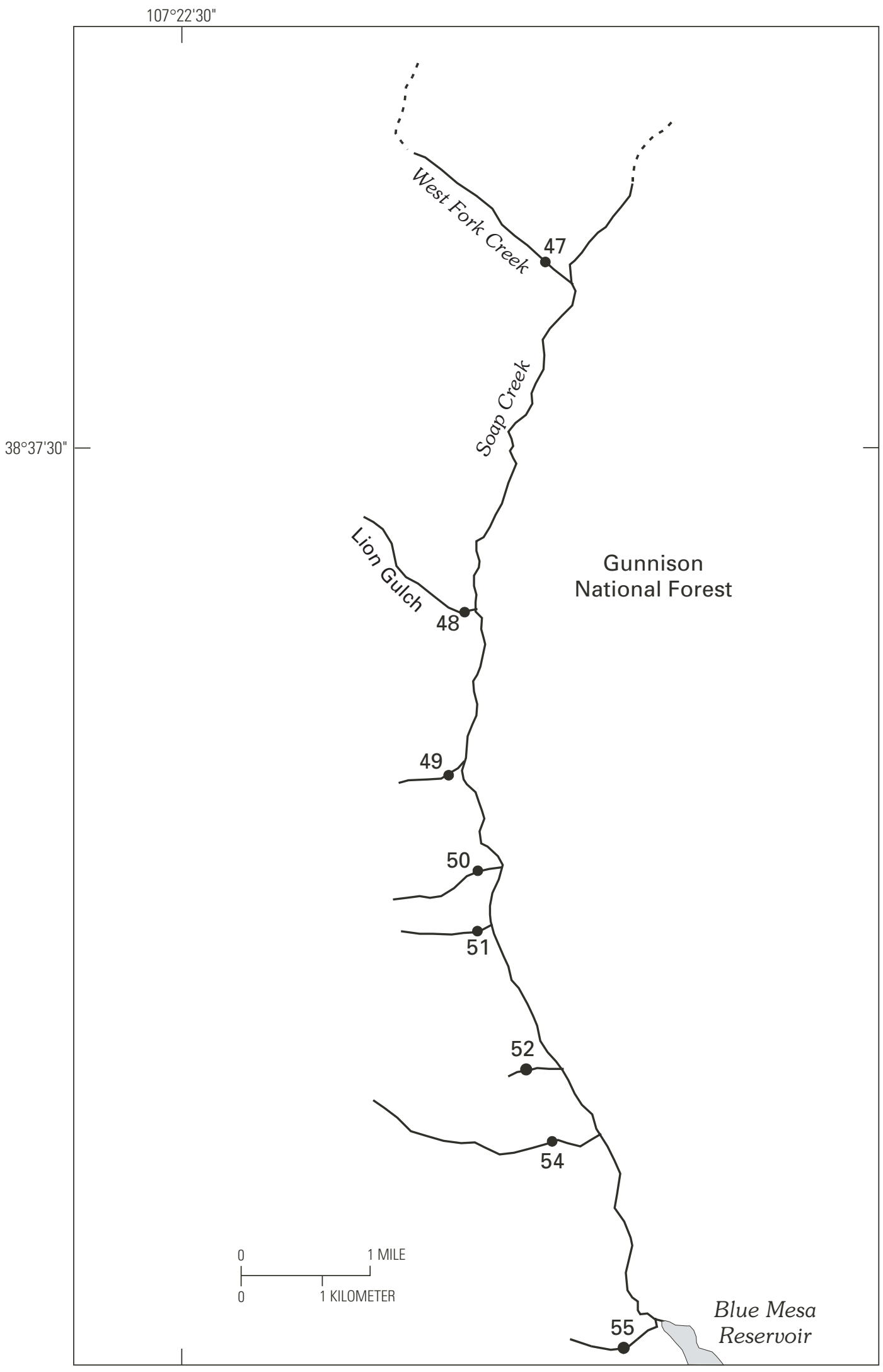

Figure 8. Site localities of stream water samples from areas underlain by Tertiary andesitic lava and breccia in the Soap Creek watershed, Gunnison National Forest, Colorado. 
Table 7. Eight stream water samples from watersheds underlain by Tertiary andesitic lava and breccia, Gunnison National Forest, Colorado.

\begin{tabular}{|c|c|c|c|}
\hline \multirow[t]{2}{*}{ Measurement ${ }^{1}$} & \multicolumn{2}{|c|}{ Range } & \multirow[t]{2}{*}{ Mean² } \\
\hline & Minimum & Maximum & \\
\hline Conductivity & 104 & 242 & 158 \\
\hline $\mathrm{pH}$ & 7.49 & 8.53 & 7.99 \\
\hline $\mathrm{Ca}$ & 10 & 22 & 16 \\
\hline $\mathrm{Mg}$ & 1.6 & 7.7 & 3 \\
\hline $\mathrm{Na}$ & 4.8 & 15 & 7.7 \\
\hline K & 0.81 & 2.4 & 1.7 \\
\hline $\mathrm{SiO}_{2}$ & 22 & 48 & 35 \\
\hline Alkalinity & 32 & 102 & 72 \\
\hline $\mathrm{SO}_{4}$ & 0.76 & 23 & 3.5 \\
\hline $\mathrm{Cl}$ & 0.34 & 1 & 0.7 \\
\hline $\mathrm{F}$ & $<0.1$ & 0.14 & $<0.1$ \\
\hline $\mathrm{Al}$ & 8.9 & 21 & 13 \\
\hline $\mathrm{Fe}$ & 8.6 & 31 & 16 \\
\hline $\mathrm{Mn}$ & $<0.3$ & 4 & 0.48 \\
\hline $\mathrm{Cu}$ & $<1$ & $<1$ & $<1$ \\
\hline $\mathrm{Zn}$ & $<0.2$ & 0.38 & 0.22 \\
\hline $\mathrm{Pb}$ & $<0.1$ & $<0.1$ & $<0.1$ \\
\hline Mo & $<0.5$ & 0.59 & $<0.5$ \\
\hline $\mathrm{Sb}$ & $<0.01$ & 0.074 & 0.012 \\
\hline As & 0.4 & 1.3 & 0.7 \\
\hline $\mathrm{Th}$ & 0.12 & 0.37 & 0.2 \\
\hline $\mathrm{U}$ & $<0.001$ & 0.28 & 0.092 \\
\hline $\mathrm{Li}$ & 0.79 & 2.9 & 1.3 \\
\hline $\mathrm{Ba}$ & 1.5 & 9.2 & 5 \\
\hline $\mathrm{Sr}$ & 60 & 149 & 95 \\
\hline V & 0.8 & 2.9 & 2.2 \\
\hline $\mathrm{Sc}$ & 26 & 54 & 41 \\
\hline $\mathrm{Rb}$ & 1.4 & 3.7 & 2.4 \\
\hline $\mathrm{Y}$ & 0.05 & 0.11 & 0.071 \\
\hline $\mathrm{Zr}$ & 0.15 & 0.45 & 0.27 \\
\hline $\mathrm{La}$ & $<0.005$ & $<0.005$ & $<0.005$ \\
\hline $\mathrm{Br}$ & $<3$ & $<3$ & $<3$ \\
\hline I & $<0.2$ & 2.2 & 0.21 \\
\hline
\end{tabular}

${ }^{1}$ Conductivity in $\mu \mathrm{S} / \mathrm{cm} ; \mathrm{Ca}, \mathrm{Mg}, \mathrm{Na}, \mathrm{K}, \mathrm{SiO}_{2}, \mathrm{SO}_{4}, \mathrm{Cl}$, and $\mathrm{F}$ in $\mathrm{mg} / \mathrm{L}$; alkalinity in $\mathrm{mg} / \mathrm{L} \mathrm{HCO}_{3}{ }^{-}$; remaining elements in $\mu \mathrm{g} / \mathrm{L}$

${ }^{2} \mathrm{All}$ variables are geometric means except for $\mathrm{pH}$, which is arithmetic mean

\section{Tertiary Sedimentary Rocks}

Samples of water were collected from seven streams draining headwater watersheds underlain by the Eocene Green River and Wasatch Formations and by the Cretaceous Ohio Creek Member of the Mesaverde Formation in Grand Mesa National Forest (fig. 9). Most of the rocks are Tertiary in age, and here they all are referred to as Tertiary sedimentary rocks. The
Wasatch Formation and the Ohio Creek Member were formed from detritus shed from the rising Rocky Mountains onto vast river flood plains and deltas that flanked an immense freshwater lake (Bradley, 1964; Roehler, 1974). The Green River sediments were deposited in the lake; accumulation of plant and animal detritus resulted in formation of oil shale (Bradley, 1964; Roehler, 1974). The sample sites were mainly selected because of the presence of outcrops of the Parachute Creek Member of the Green River Formation, which contains oil shale.

The watersheds are along the flanks of Battlement Mesa and Grand Mesa. The relief is moderate to high. The area receives 20 to 35 in. of annual precipitation (Colorado Climate Center, 1984); the higher elevations receive the most precipitation. Vegetation in the higher areas is mainly oak scrubland and subalpine forest. Grazing of cattle physically impacts some of the watersheds; an increase in sediments in the streams and deterioration of wetlands are caused by erosion by the hooves of cattle and by accumulation of cattle wastes.

The ranges and means of selected chemical species in water samples are listed in table 8 . The samples all are $\mathrm{Ca}^{2+}$ $\mathrm{HCO}_{3}{ }^{-}$type water with alkaline $\mathrm{pH}$ values and moderately high conductivity values. The mean $\mathrm{pH}$ is 8.50 and the mean conductivity is $365 \mu \mathrm{S} / \mathrm{cm}$. The water is well buffered, with mean alkalinity of $191 \mathrm{mg} / \mathrm{L}$ as $\mathrm{HCO}_{3}{ }^{-}$. The mean $\mathrm{Cl}$ concentration is $1.4 \mathrm{mg} / \mathrm{L}$. The background $\mathrm{Cl}$ for this area probably is less than $0.5 \mathrm{mg} / \mathrm{L}$, in the absence of input of $\mathrm{Cl}$ from weathering of rocks. Possibly there is some addition of $\mathrm{Cl}$ from the rocks. Halite is present in oil shale in the subsurface (Tuttle, 1992). But it is likely that some of the water may have undergone some evaporation and consequent increase in dissolved species, particularly $\mathrm{Cl}$. The mean concentration of $\mathrm{SiO}_{2}$ is $17.5 \mathrm{mg} / \mathrm{L}$, is slightly above the average background concentration for fresh water (table 3). The concentrations of $\mathrm{Cu}, \mathrm{Zn}$, and other trace metals present as cations are very low $(<1 \mu \mathrm{g} / \mathrm{L})$, although the oil shale in the Green River Formation contains anomalous concentrations of trace metals (Harrison and others, 1992). The high $\mathrm{pH}$ ensures that hydrolysis reactions keep the concentrations of trace metal cations low. The concentrations of some of the trace species, present as anions, are slightly elevated compared to average concentrations in fresh water (table 3). The mean concentrations of Mo, As, and $\mathrm{U}$ are 1.9, 1.9, and $1.4 \mu \mathrm{g}$ / $\mathrm{L}$, respectively. The concentrations of $\mathrm{I}, \mathrm{Br}, \mathrm{Li}$, and $\mathrm{Sr}$ are elevated, compared to those in fresh water (table 3). Although these element concentrations are elevated, particularly for headwater watersheds, no element poses a problem for water quality.

Five of the streams that were sampled drain watersheds that contain outcrops of the Parachute Creek Member of the Green River Formation, which contains oil shale (app. 1). Pyrite in the oil shale oxidizes when exposed to the atmosphere; it releases sulfate, trace metals contained in the pyrite, and acidity to the water. The well-buffered water with high alkalinity values reacts with and neutralizes acidity released during oxidation of pyrite, and high $\mathrm{pH}$ hydrolyzes trace metals carried as cations and reduces their mobility. Sulfate values as high as $25 \mathrm{mg} / \mathrm{L}$ (app. 1) indicate that pyrite is being weathered and sulfate is being released. If gypsum is present in the rocks, sulfate can also be released from the dissolution of gypsum. Some As values, as high as $5.8 \mu \mathrm{g} / \mathrm{L}$ (app. 1), are elevated. 


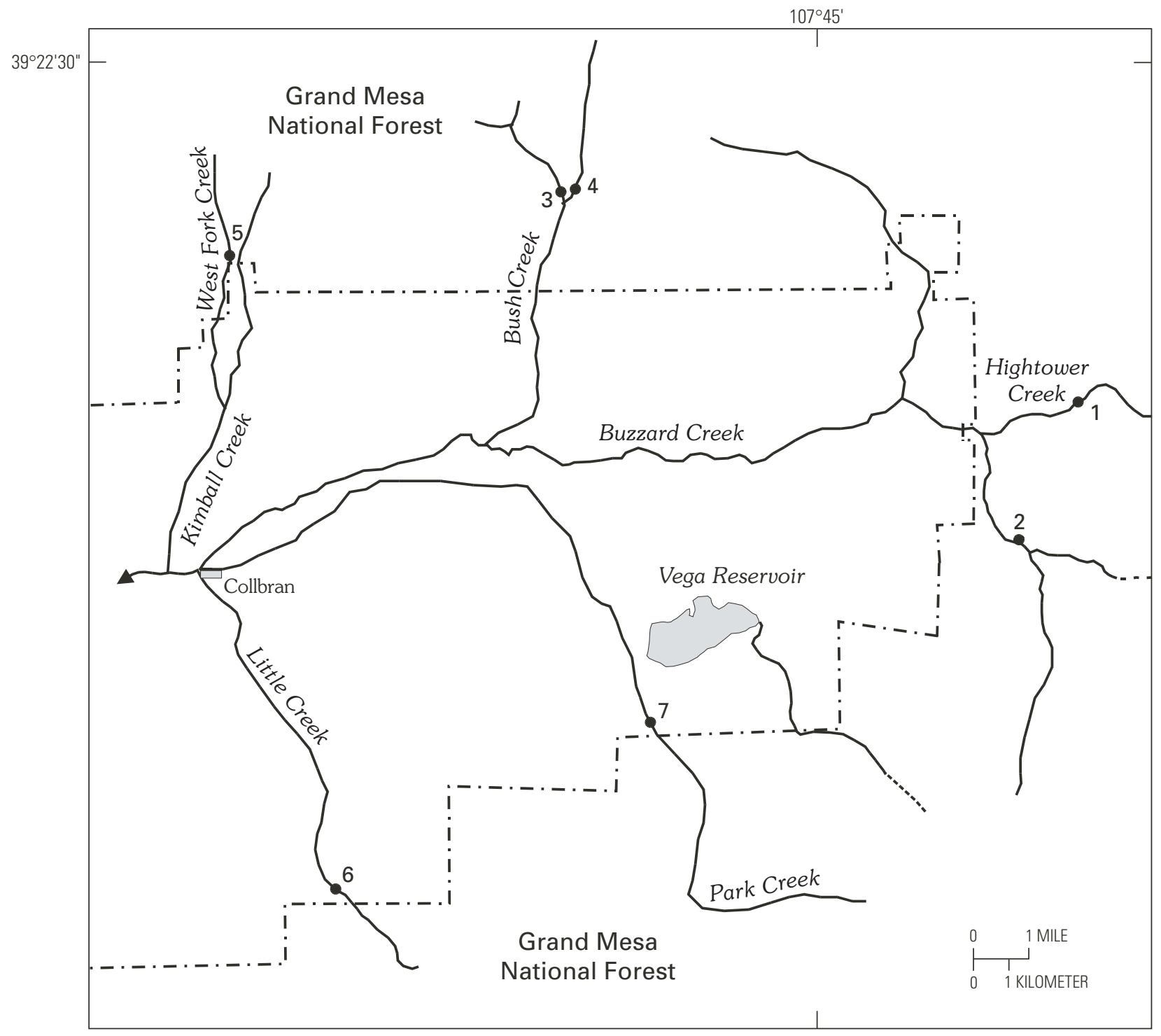

Figure 9. Site localities of stream water samples from areas underlain by Eocene Green River and Wasatch Formations and Upper Cretaceous Ohio Creek Member of Mesaverde Formation in the Buzzard Creek watershed, Grand Mesa National Forest, Colorado.

Weathering of pyrite probably causes the elevated values. However, overall there is no significant impact to the water quality of these headwater streams. The high alkalinity of the water probably is due to the presence of marlstone. The marlstone is fine grained; the calcite reacts rapidly, releasing carbonate species, mostly bicarbonate, to the water. Because of the high alkalinity, the watersheds underlain by these rock are not susceptible to introduced acidification from processes such as acid rain or acid-mine drainage. The water in the watersheds underlain by the Green River Formation, Wasatch Formation, and Ohio Creek Member are moderately high in dissolved solids, for headwater streams, but they pose no human health risk in terms of chemical water quality.

\section{Cretaceous Mesaverde Formation}

Water samples were collected from seven streams and one spring in the Coal Creek and Snowshoe Creek areas on the northern flank of the West Elk Mountains in the Gunnison National Forest (fig. 10). The ranges and means of selected chemical species in the samples are listed in table 9. Rocks of the Upper Cretaceous Mesaverde Formation underlie the area containing the sample sites. Smaller areas of Oligocene intermediate-composition intrusive rocks also are present in some watersheds. The Mesaverde Formation is mostly sandstone with some shale and coal beds. The sediments were deposited in beach, river delta, and swamp environments. The economically important low-sulfur bituminous coal beds are products of accumulation of organic material in marshes and lagoons behind sand barrier islands (Benedict, 1991). The relief in the area is high, and the annual precipitation ranges from 20 to 35 in. (Colorado Climate Center, 1984). The dominant vegetation is subalpine forest. The samples are $\mathrm{Ca}^{2+}-\mathrm{HCO}_{3}{ }^{-}$type water with alkaline $\mathrm{pH}$ values and moderate conductivity values. The $\mathrm{pH}$ values ranged from 8.00 to 8.57 , with a mean of 8.31. Conductivity values ranged from 76 to $268 \mu \mathrm{S} / \mathrm{cm}$, with a mean of 126 $\mu \mathrm{S} / \mathrm{cm}$. The mean $\mathrm{Cl}$ content is $0.49 \mathrm{mg} / \mathrm{L}$, indicating that no 
Table 8. Seven stream water samples from areas underlain by Tertiary sedimentary rocks, Grand Mesa National Forest, Colorado.

\begin{tabular}{|c|c|c|c|}
\hline \multirow[t]{2}{*}{ Measurement ${ }^{1}$} & \multicolumn{2}{|c|}{ Range } & \multirow[t]{2}{*}{ Mean $^{2}$} \\
\hline & Minimum & Maximum & \\
\hline Conductivity & 195 & 652 & 365 \\
\hline $\mathrm{pH}$ & 8.16 & 8.69 & 8.50 \\
\hline $\mathrm{Ca}$ & 18 & 62 & 39 \\
\hline $\mathrm{Mg}$ & 6.6 & 37 & 12 \\
\hline $\mathrm{Na}$ & 5.2 & 45 & 15 \\
\hline $\mathrm{K}$ & 0.65 & 3.8 & 1.4 \\
\hline $\mathrm{SiO}_{2}$ & 6.5 & 27 & 18 \\
\hline Alkalinity & 92 & 352 & 191 \\
\hline $\mathrm{SO}_{4}$ & 3.4 & 25 & 8.1 \\
\hline $\mathrm{Cl}$ & 0.63 & 8.3 & 1.4 \\
\hline $\mathrm{F}$ & $<0.1$ & 0.51 & 0.16 \\
\hline $\mathrm{Al}$ & $<3$ & 24 & 12 \\
\hline $\mathrm{Fe}$ & $<5$ & 36 & 13 \\
\hline Mn & $<0.3$ & 171 & 4.7 \\
\hline $\mathrm{Cu}$ & $<1$ & 1.7 & $<1$ \\
\hline $\mathrm{Zn}$ & $<0.2$ & 0.53 & 0.22 \\
\hline $\mathrm{Pb}$ & $<0.1$ & 2.9 & 0.18 \\
\hline Mo & 0.53 & 7.5 & 1.9 \\
\hline $\mathrm{Sb}$ & $<0.01$ & 0.29 & 0.12 \\
\hline As & 0.62 & 5.8 & 1.9 \\
\hline $\mathrm{Th}$ & 0.18 & 1.5 & 0.36 \\
\hline $\mathrm{U}$ & 0.39 & 8.8 & 1.4 \\
\hline $\mathrm{Li}$ & 1.3 & 25 & 7.2 \\
\hline $\mathrm{Ba}$ & 32 & 208 & 62 \\
\hline $\mathrm{Sr}$ & 114 & 718 & 311 \\
\hline V & 1.3 & 5.5 & 2.8 \\
\hline $\mathrm{Sc}$ & 11 & 36 & 25 \\
\hline $\mathrm{Rb}$ & 0.4 & 0.84 & 0.6 \\
\hline $\mathrm{Y}$ & 0.05 & 0.17 & 0.083 \\
\hline $\mathrm{Zr}$ & 0.14 & 1.3 & 0.42 \\
\hline $\mathrm{La}$ & $<0.005$ & 0.072 & 0.017 \\
\hline $\mathrm{Br}$ & $<3$ & 182 & 6.6 \\
\hline I & $<0.2$ & 36 & 1.5 \\
\hline
\end{tabular}

${ }^{1}$ Conductivity in $\mu \mathrm{S} / \mathrm{cm}$; $\mathrm{Ca}, \mathrm{Mg}, \mathrm{Na}, \mathrm{K}, \mathrm{SiO}_{2}, \mathrm{SO}_{4}, \mathrm{Cl}$, and $\mathrm{F}$ in $\mathrm{mg} / \mathrm{L}$;

alkalinity in $\mathrm{mg} / \mathrm{L} \mathrm{HCO}_{3}{ }^{-}$; remaining elements in $\mu \mathrm{g} / \mathrm{L}$

${ }^{2} \mathrm{All}$ variables are geometric means except for $\mathrm{pH}$, which is arithmetic mean
Table 9. Summary of the chemistry of seven stream water samples and one spring from areas underlain by the Cretaceous Mesaverde Formation water sample, Gunnison National Forest, Colorado.

\begin{tabular}{|c|c|c|c|}
\hline \multirow[t]{2}{*}{ Measurement ${ }^{1}$} & \multicolumn{2}{|c|}{ Range } & \multirow[t]{2}{*}{ Mean² } \\
\hline & Minimum & Maximum & \\
\hline Conductivity & 76 & 268 & 126 \\
\hline $\mathrm{pH}$ & 8 & 8.57 & 8.31 \\
\hline $\mathrm{Ca}$ & 7.7 & 31 & 13 \\
\hline $\mathrm{Mg}$ & 1.3 & 8.3 & 3 \\
\hline $\mathrm{Na}$ & 3.8 & 13.4 & 5.4 \\
\hline $\mathrm{K}$ & 0.32 & 0.81 & 0.49 \\
\hline $\mathrm{SiO}_{2}$ & 11 & 15 & 13 \\
\hline Alkalinity & 34 & 122 & 54 \\
\hline $\mathrm{SO}_{2}$ & 1.5 & 19 & 5.3 \\
\hline $\mathrm{Cl}$ & 0.25 & 1 & 0.49 \\
\hline $\mathrm{F}$ & $<0.1$ & 0.75 & 0.11 \\
\hline $\mathrm{Al}$ & 9 & 27 & 12 \\
\hline $\mathrm{Fe}$ & $<5$ & 30 & 14 \\
\hline $\mathrm{Mn}$ & 1.4 & 7 & 2 \\
\hline $\mathrm{Cu}$ & $<1$ & $<1$ & $<1$ \\
\hline $\mathrm{Zn}$ & $<0.2$ & 0.36 & 0.24 \\
\hline $\mathrm{Pb}$ & $<0.1$ & $<0.1$ & $<0.1$ \\
\hline Mo & $<0.5$ & 0.63 & $<0.5$ \\
\hline $\mathrm{Sb}$ & $<0.01$ & $<0.01$ & $<0.01$ \\
\hline As & $<0.03$ & 2.4 & 0.08 \\
\hline Th & $<0.002$ & 0.023 & 0.003 \\
\hline $\mathrm{U}$ & 0.077 & 0.51 & 0.13 \\
\hline $\mathrm{Li}$ & 0.72 & 4.7 & 1.4 \\
\hline $\mathrm{Ba}$ & 11 & 49 & 18 \\
\hline $\mathrm{Sr}$ & 52 & 364 & 189 \\
\hline $\mathrm{V}$ & $<0.5$ & 0.74 & $<0.5$ \\
\hline $\mathrm{Sc}$ & 16 & 21 & 18 \\
\hline $\mathrm{Rb}$ & 0.14 & 0.45 & 0.32 \\
\hline $\mathrm{Y}$ & $<0.03$ & 0.12 & 0.042 \\
\hline $\mathrm{Zr}$ & $<0.05$ & 0.62 & 0.15 \\
\hline $\mathrm{La}$ & $<0.005$ & 0.089 & $<0.005$ \\
\hline $\mathrm{Br}$ & $<3$ & $<3$ & $<3$ \\
\hline I & $<0.2$ & $<0.2$ & $<0.2$ \\
\hline $\begin{array}{l}\text { Conductivity in } \mu \mathrm{S} / \\
\text { alkalinity in } \mathrm{mg} / \mathrm{L}\end{array}$ & $\begin{array}{l}\mathrm{Mg}, \mathrm{Na}, \mathrm{K} \\
\text { remaining }\end{array}$ & $\begin{array}{l}\mathrm{O}_{4}, \mathrm{Cl} \text {, an } \\
\text { in } \mu \mathrm{g} / \mathrm{L}\end{array}$ & $\mathrm{mg} / \mathrm{L}$ \\
\hline
\end{tabular}

minerals. The concentrations of trace elements $\mathrm{Zn}, \mathrm{Cu}, \mathrm{Mo}$, and As are very low, with means of $0.24,<1,<0.5$, and $<0.08 \mu \mathrm{g} / \mathrm{L}$, respectively. Concentrations of $\mathrm{Al}, \mathrm{Fe}$, and $\mathrm{Mn}$ also are low with means of 12,14 , and $2 \mu \mathrm{g} / \mathrm{L}$, respectively. Alkalinity values range from 34 to $122 \mathrm{mg} / \mathrm{L}$ as $\mathrm{HCO}_{3}{ }^{-}$with a mean of 54 $\mathrm{mg} / \mathrm{L}$. This wide range in alkalinity values possibly is due to the local presence of pyrite associated with the coal beds. Sulfate concentrations range up to $19 \mathrm{mg} / \mathrm{L}$ with a mean of $5.3 \mathrm{mg} / \mathrm{L}$. significant evaporation and no long-term contact of the water with the rocks occurred. A significant portion of the stream water probably is snowmelt. The range of concentrations of $\mathrm{SiO}_{2}$ is 11 to $15 \mathrm{mg} / \mathrm{L}$, with a mean of $13 \mathrm{mg} / \mathrm{L}$, about average for fresh water (table 3). Waters from areas underlain by sandstone contain less $\mathrm{SiO}_{2}$ than do waters from areas underlain by ash-flow tuff and andesitic rocks; this probably reflects the coarse grain size and well crystallized nature of the silica 


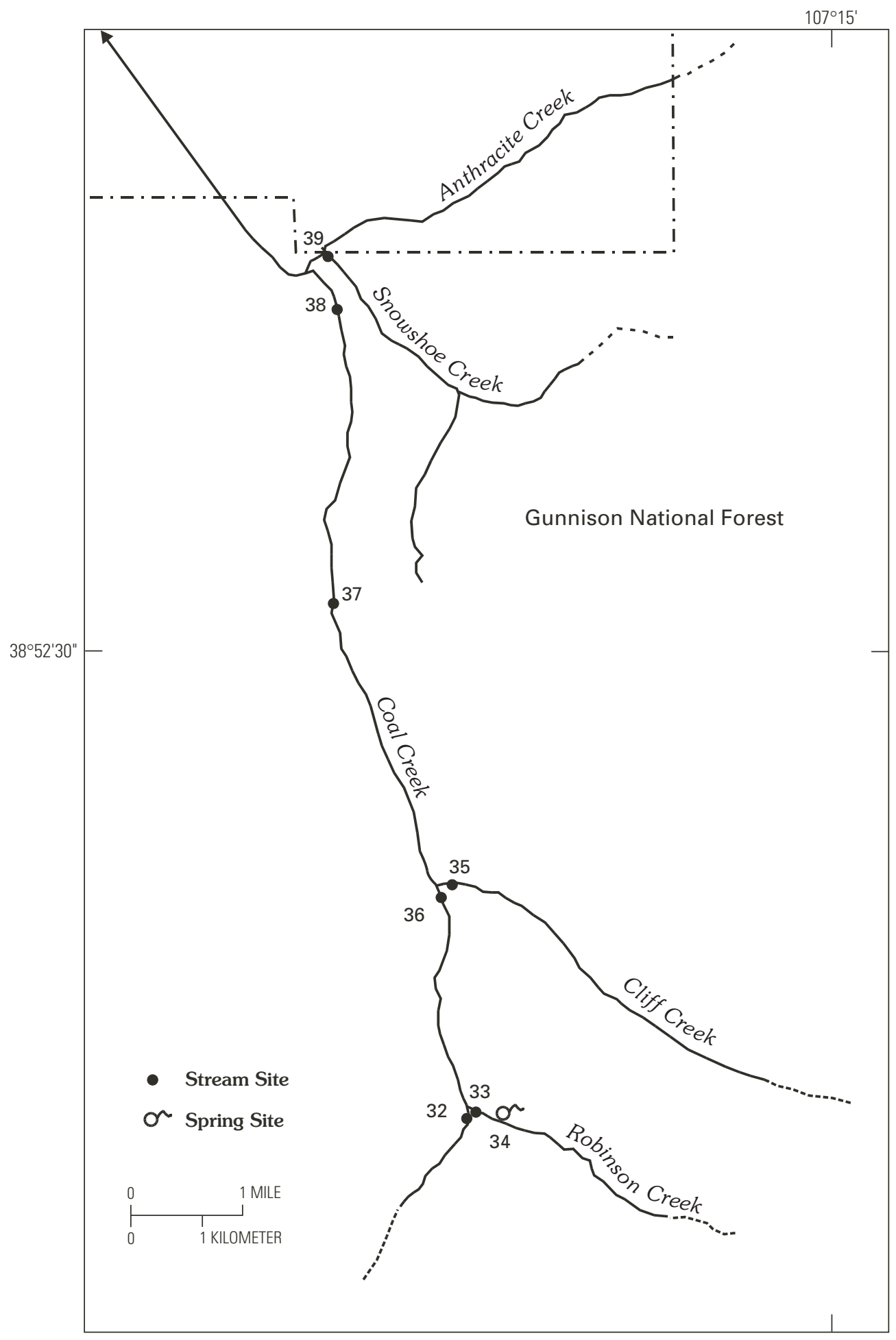

Figure 10. Site localities of stream and spring water samples from areas underlain by Cretaceous Mesaverde Formation in the Coal Creek and Snowshoe Creek watersheds, Gunnison National Forest, Colorado.

Weathering of pyrite releases sulfate and acid to the waters, and the acid consumes some of the alkalinity. The moderately low mean alkalinity indicates a low to moderate acid-neutralizing capacity of the watershed to introduced acidification. Overall, the water quality is good.

\section{Cretaceous Mancos Shale}

Water samples were collected from two areas underlain by Mancos Shale. Six streams were sampled in the southwestern 
part of the Uncompahgre National Forest, in the Beaver and Goat Creek watersheds (fig. 11). Two springs were sampled along the northwest flank of the West Elk Mountains, in the area of Bell Creek in the Gunnison National Forest (fig. 12). The ranges and means of selected chemical species in the samples are listed in table 10. The Cretaceous Mancos Shale consists of silty and sandy shale and thin-bedded sandstone with calcareous zones; it was deposited in a marine setting. Relief in the two areas is high and the annual precipitation ranges from 16 to 40 in. (Colorado Climate Center, 1984). The dominant vegetation in both areas is subalpine forest; in lower areas outside the national forest, badland topography with sparse scrub vegetation is present. The samples all are $\mathrm{Ca}^{2+}-\mathrm{HCO}_{3}{ }^{-}$type water with alkaline $\mathrm{pH}$ values and moderately high conductivity values. The $\mathrm{pH}$ values range from 7.46 to 8.58 , with a mean of 8.20. The conductivity values range from 107 to $401 \mu \mathrm{S} / \mathrm{cm}$, with a mean of $258 \mu \mathrm{S} / \mathrm{cm}$. The mean $\mathrm{Cl}$ content is $0.6 \mathrm{mg} / \mathrm{L}$, indication that evaporation and duration of contact of the water with rock and soil were not significant. It is possible that some of the $\mathrm{Cl}$ is a product of rock weathering, but the low concentration of $\mathrm{Cl}$ indicates that this process is insignificant. Note that these sites are at higher elevations and chemical processes at these sites are not necessarily the same as those at lower elevations in less-vegetated areas underlain by the Mancos Shale outside the national forests. The mean concentration of $\mathrm{SiO}_{2}$ is $13 \mathrm{mg} / \mathrm{L}$, about average for fresh water (table 3 ). Concentrations of trace elements generally are low, with mean $\mathrm{Zn}, \mathrm{Cu}, \mathrm{Mo}$, and As values of $0.21,<1,0.71$, and $0.12 \mu \mathrm{g} / \mathrm{L}$, respectively. High Se concentrations in samples from the lower parts of valleys are a problem. One possible cause is high Se concentrations in the Mancos Shale (Wright and Butler, 1993). In the headwater watersheds underlain by the Mancos Shale, Se concentrations in all of the water samples are $<0.2 \mu \mathrm{g} / \mathrm{L}$. The high Se concentrations in the lower parts of valleys probably are a result of evaporation effects from natural processes and irrigation. Se, similar to $\mathrm{Cl}$, is concentrated as a result of evaporation. The concentrations of $\mathrm{Al}, \mathrm{Fe}$, and $\mathrm{Mn}$ are low, at 10, 15, and $2.2 \mu \mathrm{g} / \mathrm{L}$, respectively. The alkalinity values are moderately high; they range from 30 to $180 \mathrm{mg} / \mathrm{L}$ as $\mathrm{HCO}_{3}{ }^{-}$, with a mean of $101 \mathrm{mg} / \mathrm{L}$. The moderately high alkalinity probably is due to the presence of calcareous zones in the bedrock. These values of alkalinity indicate that the water in mountainous headwater areas

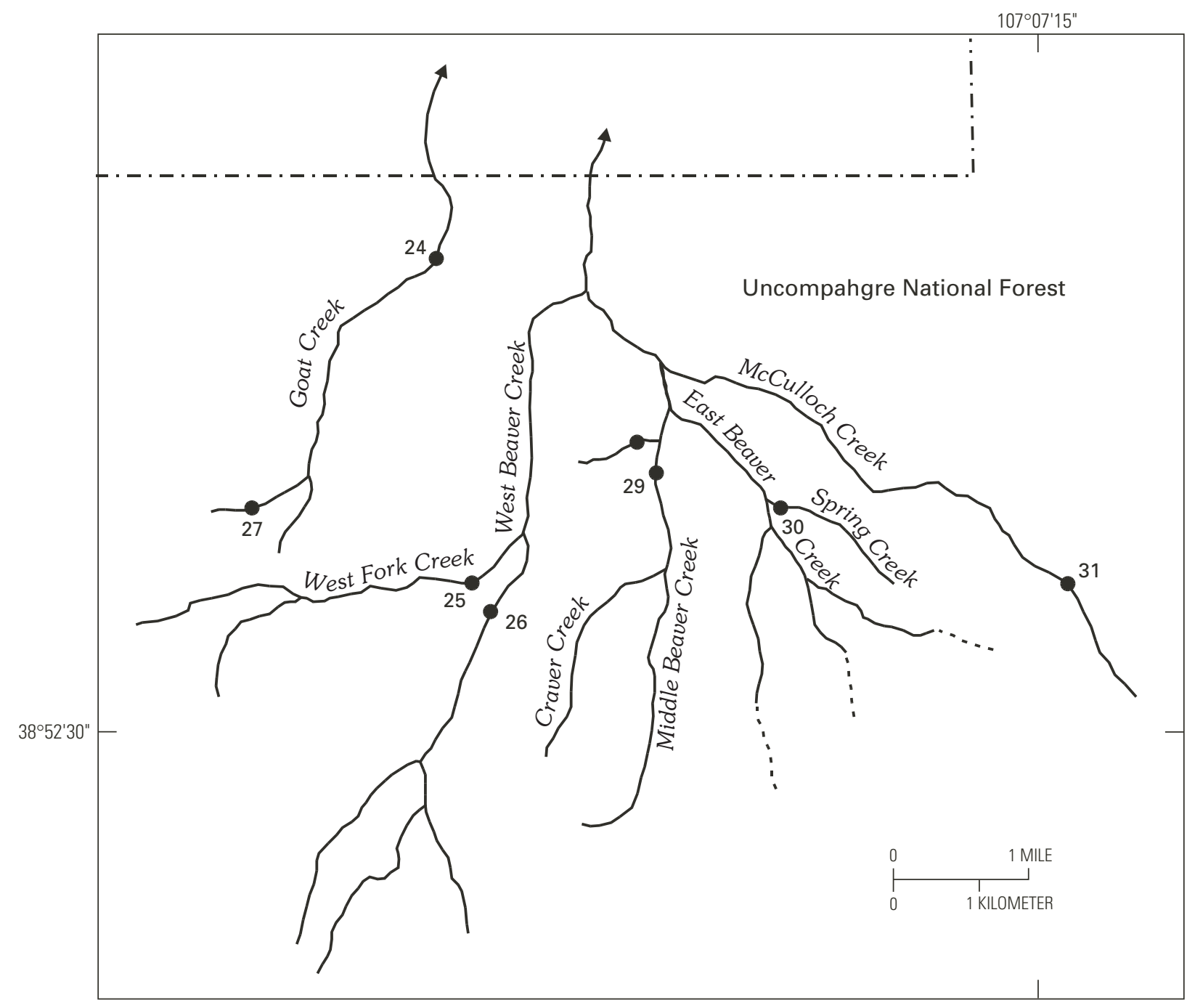

Figure 11. Site localities of stream water samples from areas underlain by Cretaceous Mancos Shale in the Beaver and Goat Creek watersheds, Uncompahgre National Forest, Colorado. 


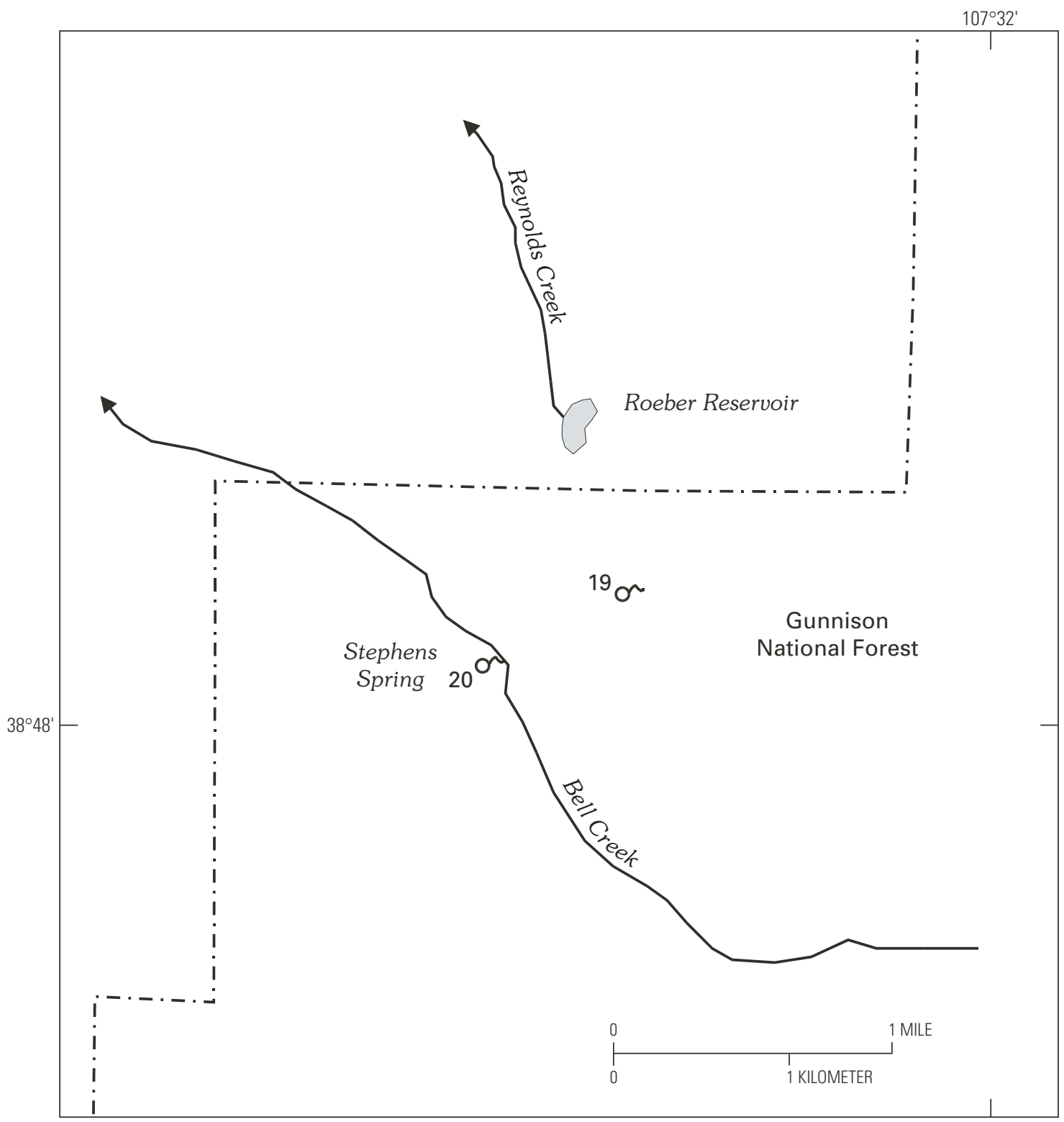

Figure 12. Site localities of spring water samples from areas underlain by Cretaceous Mancos Shale in the Bell Creek area, Gunnison National Forest, Colorado.

underlain by the Mancos Shale has moderate acid-neutralizing capacity to introduced acidification. Except for the moderately high dissolved solid content, the water quality is good.

\section{Mesozoic Sedimentary Rocks}

Water samples were collected from one stream and four springs on the summit and east flank of the Uncompahgre Plateau in the Uncompahgre National Forest (fig. 13). The ranges and means of selected chemical species in the samples are listed in table 11. Cretaceous, Jurassic, and Triassic sedimentary rocks underlie the area. Dominant units include the Cretaceous Dakota Sandstone and Burro Canyon Formation; the Jurassic Morrison Formation, Summerville Formation, Entrada Sandstone, and Wingate Sandstone, and the Triassic Chinle Formation (Tweto, 1979). The rocks are mostly sandstone, siltstone, mudstone, and conglomerate. They are dominantly terrestrial in origin and most are fluvial; however dune, flood-plain, and lacustrine deposits also are present. Many of the rocks were deposited in a warm, dry environment. Rocks of marine origin that are included consist of shale and limestone. Several of the units, particularly the Morrison, Entrada, and Chinle Formations, contain uranium and vanadium deposits along the west flank of the Uncompahgre Plateau outside the Uncompahgre National Forest boundaries. Impure coal beds are present in the Dakota Sandstone. The relief ranges from moderate, along the top, to high, along the flanks of the plateau. The annual precipitation ranges from 16 to 25 in. (Colorado Climate Center, 1984). The dominant vegetation is mainly subalpine forest, although scrublands are present along the lower slopes.

The stream and spring samples are $\mathrm{Ca}^{2+}-\mathrm{HCO}_{3}{ }^{-}$type water with alkaline $\mathrm{pH}$ values and moderately high conductivity values. The range in $\mathrm{pH}$ values is 7.48 to 8.53 , with a mean 
Table 10. Summary of the chemistry of eight stream water samples and two spring water samples from areas underlain by the Cretaceous Mancos Shale, Gunnison and Uncompahgre National Forest, Colorado.

\begin{tabular}{|c|c|c|c|}
\hline \multirow[t]{2}{*}{ Measurement ${ }^{1}$} & \multicolumn{2}{|c|}{ Range } & \multirow[t]{2}{*}{ Mean² } \\
\hline & Minimum & Maximum & \\
\hline Conductivity & 107 & 401 & 258 \\
\hline $\mathrm{pH}$ & 7.46 & 8.58 & 8.20 \\
\hline $\mathrm{Ca}$ & 12 & 50 & 32 \\
\hline $\mathrm{Mg}$ & 2.3 & 13 & 7.5 \\
\hline $\mathrm{Na}$ & 2.5 & 13 & 4.7 \\
\hline $\mathrm{K}$ & 0.15 & 1 & 0.36 \\
\hline $\mathrm{SiO}_{2}$ & 8.6 & 27 & 13 \\
\hline Alkalinity & 30 & 180 & 101 \\
\hline $\mathrm{SO}_{4}$ & 6.1 & 37 & 18 \\
\hline $\mathrm{Cl}$ & 0.26 & 1.9 & 0.6 \\
\hline $\mathrm{F}$ & $<0.1$ & 0.19 & 0.12 \\
\hline $\mathrm{Al}$ & 4.5 & 16 & 10 \\
\hline $\mathrm{Fe}$ & $<5$ & 60 & 15 \\
\hline $\mathrm{Mn}$ & $<0.3$ & 29 & 2.2 \\
\hline $\mathrm{Cu}$ & $<1$ & $<1$ & $<1$ \\
\hline $\mathrm{Zn}$ & $<0.2$ & 0.47 & 0.21 \\
\hline $\mathrm{Pb}$ & $<0.1$ & $<0.1$ & $<0.1$ \\
\hline Мо & $<0.5$ & 1.7 & 0.71 \\
\hline $\mathrm{Sb}$ & $<0.01$ & 0.14 & 0.015 \\
\hline As & $<0.03$ & 0.48 & 0.12 \\
\hline $\mathrm{Th}$ & 0.02 & 0.062 & 0.032 \\
\hline $\mathrm{U}$ & 0.12 & 0.58 & 0.27 \\
\hline $\mathrm{Li}$ & $<0.5$ & 5.9 & 1.6 \\
\hline $\mathrm{Ba}$ & 4.8 & 35 & 18 \\
\hline $\mathrm{Sr}$ & 39 & 581 & 169 \\
\hline $\mathrm{V}$ & $<0.5$ & 1.7 & 0.43 \\
\hline $\mathrm{Sc}$ & 14 & 35 & 19 \\
\hline $\mathrm{Rb}$ & 0.052 & 0.65 & 0.16 \\
\hline $\mathrm{Y}$ & 0.034 & 0.13 & 0.053 \\
\hline $\mathrm{Zr}$ & $<0.05$ & 0.42 & 0.067 \\
\hline $\mathrm{La}$ & $<0.005$ & $<0.005$ & $<0.005$ \\
\hline $\mathrm{Br}$ & $<3$ & $<3$ & $<3$ \\
\hline I & $<0.2$ & 3.9 & 0.51 \\
\hline
\end{tabular}

${ }^{1}$ Conductivity in $\mu \mathrm{S} / \mathrm{cm}$; $\mathrm{Ca}, \mathrm{Mg}, \mathrm{Na}, \mathrm{K}, \mathrm{SiO}_{2}, \mathrm{SO}_{4}, \mathrm{Cl}$, and $\mathrm{F}$ in $\mathrm{mg} / \mathrm{L}$; alkalinity in $\mathrm{mg} / \mathrm{L} \mathrm{HCO}_{3}{ }^{-}$; remaining elements in $\mu \mathrm{g} / \mathrm{L}$

${ }^{2} \mathrm{All}$ variables are geometric means except for $\mathrm{pH}$, which is arithmetic mean

of 7.94. The range in conductivity values is 299 to $527 \mu \mathrm{S} / \mathrm{cm}$, with a mean of $413 \mu \mathrm{S} / \mathrm{cm}$. The mean $\mathrm{Cl}$ concentration is 3.5 $\mathrm{mg} / \mathrm{L}$, indicating that the water was in longer contact with rocks than surface water and that there was evaporation and concentration. Four of the samples are ground water from springs (fig. 13). The mean $\mathrm{SiO}_{2}$ concentration is $10.9 \mathrm{mg} / \mathrm{L}$, which is low compared to average fresh water (table 3 ). The low $\mathrm{SiO}_{2}$ concentration probably reflects the large grain size
Table 11. Summary of the chemistry of one stream water sample and four spring water samples from areas underlain by Mesozoic sedimentary rocks, Uncompahgre National Forest, Colorado.

\begin{tabular}{|c|c|c|c|}
\hline \multirow[t]{2}{*}{ Measurement ${ }^{1}$} & \multicolumn{2}{|c|}{ Range } & \multirow[t]{2}{*}{ Mean² } \\
\hline & Minimum & Maximum & \\
\hline Conductivity & 299 & 527 & 413 \\
\hline $\mathrm{pH}$ & 7.48 & 8.53 & 7.94 \\
\hline $\mathrm{Ca}$ & 43 & 84 & 59 \\
\hline $\mathrm{Mg}$ & 7.4 & 14 & 10 \\
\hline $\mathrm{Na}$ & 2 & 15 & 5.2 \\
\hline K & 1.3 & 2.8 & 1.8 \\
\hline $\mathrm{SiO}_{2}$ & 6.9 & 19 & 10.9 \\
\hline Alkalinity & 152 & 262 & 205 \\
\hline $\mathrm{SO}_{4}$ & 2.5 & 7.9 & 4.7 \\
\hline $\mathrm{Cl}$ & 1.6 & 6.1 & 3.5 \\
\hline $\mathrm{F}$ & $<0.1$ & 0.15 & 0.12 \\
\hline $\mathrm{Al}$ & $<3$ & 18 & 6.7 \\
\hline $\mathrm{Fe}$ & $<5$ & 25 & 4.6 \\
\hline $\mathrm{Mn}$ & $<0.3$ & 3.9 & 0.68 \\
\hline $\mathrm{Cu}$ & $<1$ & 1 & $<1$ \\
\hline $\mathrm{Zn}$ & $<0.2$ & 0.29 & 0.23 \\
\hline $\mathrm{Pb}$ & $<0.1$ & 1.7 & 0.13 \\
\hline Mo & $<0.5$ & 0.65 & $<0.5$ \\
\hline $\mathrm{Sb}$ & $<0.01$ & 0.086 & 0.019 \\
\hline As & 0.33 & 2.8 & 1.2 \\
\hline Th & 0.045 & 0.094 & 0.07 \\
\hline $\mathrm{U}$ & 1.4 & 5.8 & 2.7 \\
\hline $\mathrm{Li}$ & 7.9 & 20 & 12 \\
\hline $\mathrm{Ba}$ & 227 & 439 & 286 \\
\hline $\mathrm{Sr}$ & 161 & 535 & 241 \\
\hline $\mathrm{V}$ & $<0.5$ & 2.7 & 0.68 \\
\hline $\mathrm{Sc}$ & 11 & 25 & 15 \\
\hline $\mathrm{Rb}$ & 1.5 & 4 & 2.4 \\
\hline $\mathrm{Y}$ & $<0.03$ & 0.2 & 0.035 \\
\hline $\mathrm{Zr}$ & $<0.05$ & 0.44 & 0.14 \\
\hline $\mathrm{La}$ & $<0.005$ & 0.064 & 0.005 \\
\hline $\mathrm{Br}$ & $<3$ & 78 & 8 \\
\hline I & $<0.2$ & 5.5 & 0.98 \\
\hline
\end{tabular}

${ }^{1}$ Conductivity in $\mu \mathrm{S} / \mathrm{cm}$; $\mathrm{Ca}, \mathrm{Mg}, \mathrm{Na}, \mathrm{K}, \mathrm{SiO}_{2}, \mathrm{SO}_{4}, \mathrm{Cl}$, and $\mathrm{F}$ in $\mathrm{mg} / \mathrm{L}$; alkalinity in $\mathrm{mg} / \mathrm{L} \mathrm{HCO}_{3}{ }^{-}$; remaining elements in $\mu \mathrm{g} / \mathrm{L}$

${ }^{2} \mathrm{All}$ variables are geometric means except for $\mathrm{pH}$, which is arithmetic mean

and well-crystallized mineral grains in the sandstone. The mean concentrations of trace elements $\mathrm{Zn}, \mathrm{Cu}, \mathrm{Mo}$, and As are low, at $0.23,<1,<0.5$, and $1.2 \mu \mathrm{g} / \mathrm{L}$, respectively, but the mean concentrations of $\mathrm{U}$ and As are elevated, at 2.7 and $1.2 \mu \mathrm{g} / \mathrm{L}$, respectively, compared to average fresh water (table 3). The mean concentrations of $\mathrm{Al}, \mathrm{Fe}$, and $\mathrm{Mn}$ are low, at 6.7, 4.6, and $0.68 \mu \mathrm{g} / \mathrm{L}$, respectively. The alkalinity values are high, from 152 to $262 \mathrm{mg} / \mathrm{L}$ as $\mathrm{HCO}_{3}{ }^{-}$, with a mean of $205 \mathrm{mg} / \mathrm{L}$. The 


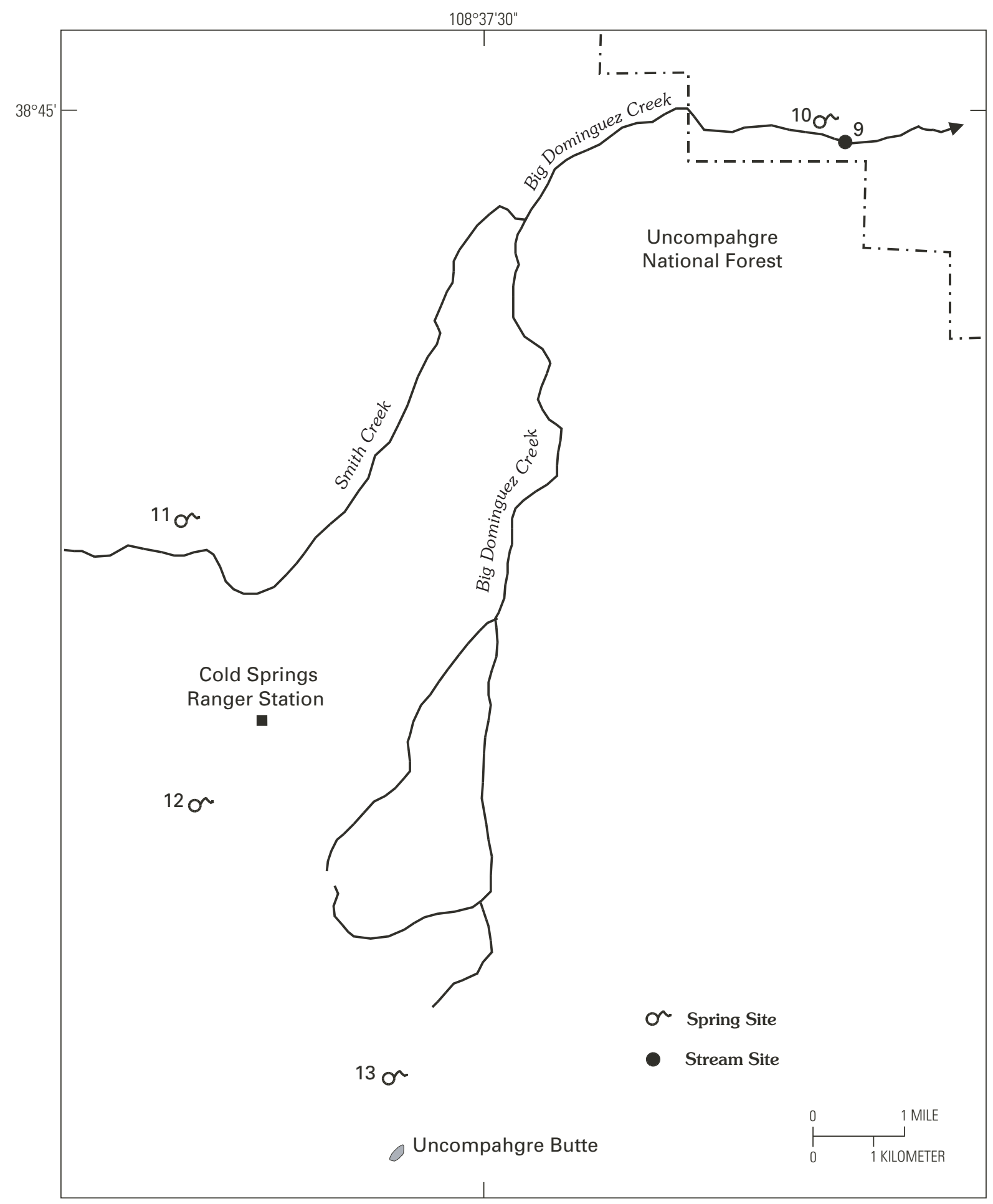

Figure 13. Site localities of stream and spring water samples from areas underlain by Mesozoic sedimentary rocks along the top and east flank of the Uncompahgre Plateau, Uncompahgre National Forest, Colorado.

high alkalinity values probably are a result of the presence of fine-grained, poorly crystallized calcite in marlstones and lacustrine deposits and as cement in sandstone. The high alkalinity ensures that the water from this area has good acidneutralizing capacities to introduced acidification. The water is moderately high in total dissolved solids, compared to values from headwater areas; otherwise it is of good chemical quality.

\section{Paleozoic Sedimentary Rocks}

Water samples were collected from 14 streams and one spring in the Cement Creek and Spring Creek drainages along the west flank of the Sawatch Range in Gunnison National Forest (fig. 14). The ranges and means of selected chemical species in the samples are listed in table 12. Paleozoic sedimentary 


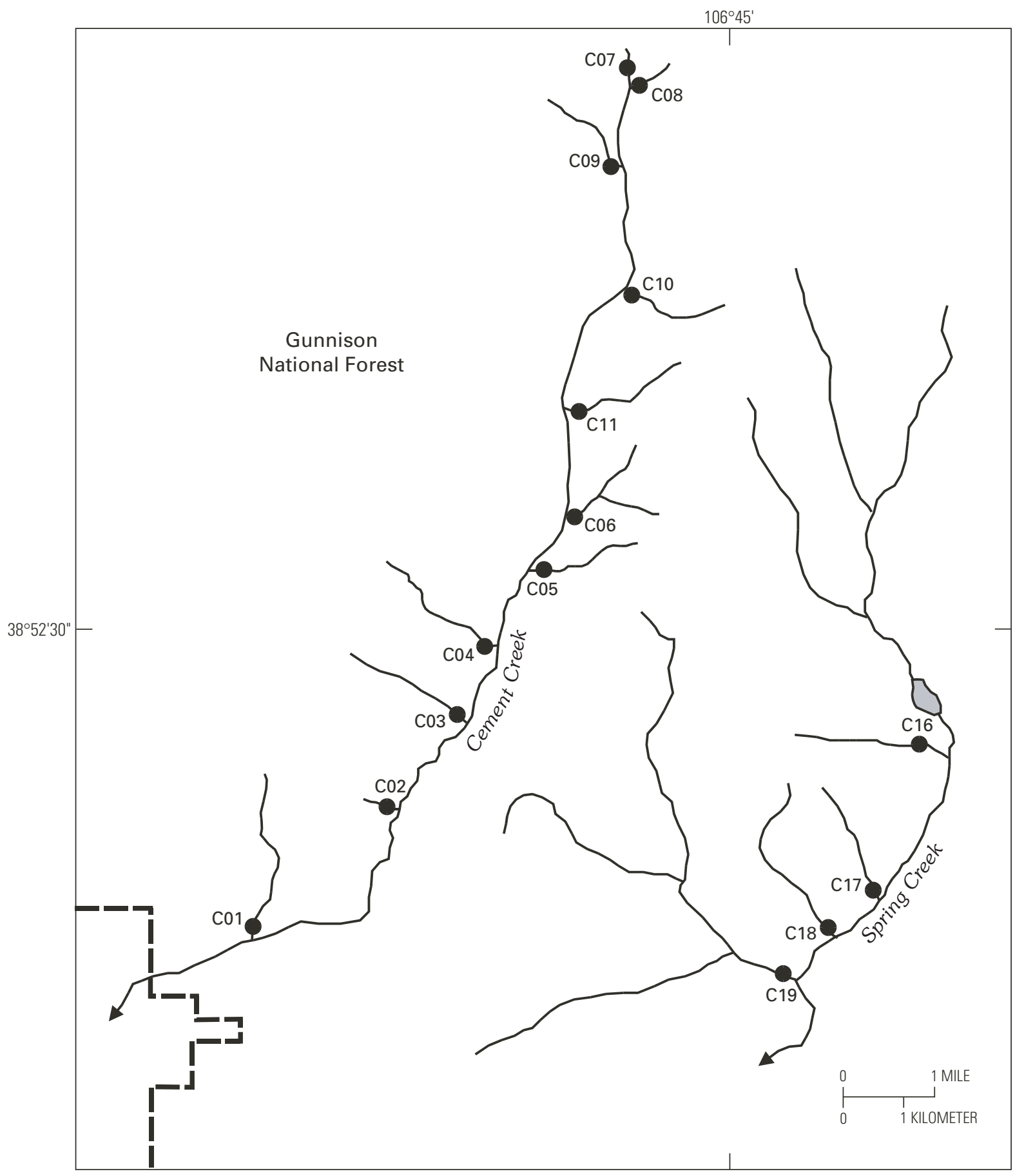

Figure 14. Site localities of stream and spring water samples from areas underlain by Paleozoic sedimentary rocks, in the Cement Creek watershed, Gunnison National Forest, Colorado.

rocks underlie the area. The dominant rock units include the Permian and Pennsylvanian Maroon Formation; the Pennsylvanian Minturn and Belden Formations; the Mississippian Leadville Limestone; the Ordovician Manitou Dolomite; and the Cambrian Sawatch quartzite (Tweto, 1976). The rocks are mostly limestone, dolomite, arkosic sandstone, conglomerate, and shale. The relief is high, and annual precipitation ranges from 25 to 40 in. (Colorado Climate Center, 1984). The dominant vegetation is mainly subalpine forest.

Fourteen samples are $\mathrm{Ca}^{2+}-\mathrm{HCO}_{3}^{-}$type water and one sample is $\mathrm{Ca}^{2+}-\mathrm{SO}_{4}{ }^{2-}$ type water. The $\mathrm{pH}$ values are alkaline and the conductivity values are high. The range in $\mathrm{pH}$ is 7.97 to 8.59 , with a mean of 8.30 . The range in conductivity values is 225 to $659 \mu \mathrm{S} / \mathrm{cm}$, with a mean of $356 \mu \mathrm{S} / \mathrm{cm}$. The mean $\mathrm{Cl}$ concentration is $<0.25 \mathrm{mg} / \mathrm{L}$, which is low. It reflects the short residence time of the water from melting snow and storm runoff in contact with the rocks and also a lack of significant evaporation. The mean $\mathrm{SiO}_{2}$ concentration is $6.3 \mathrm{mg} / \mathrm{L}$, which is low compared to average fresh water (table 3 ). The low concentration probably reflects the large grain size and well-crystallized grains of the silicate minerals and the abundance of carbonate minerals. The sulfate concentrations range from 0.85 to 204 
Table 12. Summary of fourteen stream water samples and one spring water sample from watersheds underlain by Paleozoic sedimentary rocks, Gunnison National Forest, Colorado.

\begin{tabular}{|c|c|c|c|}
\hline \multirow[t]{2}{*}{ Measurement ${ }^{1}$} & \multicolumn{2}{|c|}{ Range } & \multirow[t]{2}{*}{ Mean² } \\
\hline & Minimum & Maximum & \\
\hline Conductivity & 225 & 659 & 356 \\
\hline $\mathrm{pH}$ & 7.97 & 8.59 & 8.30 \\
\hline $\mathrm{Ca}$ & 40.6 & 101 & 52.6 \\
\hline $\mathrm{Mg}$ & 2.94 & 25 & 11 \\
\hline $\mathrm{Na}$ & 0.61 & 5.4 & 1.3 \\
\hline $\mathrm{K}$ & 0.11 & 1.3 & 0.47 \\
\hline $\mathrm{SiO}_{2}$ & 3.7 & 12 & 6.31 \\
\hline Alkalinity & 110 & 194 & 143 \\
\hline $\mathrm{SO}_{4}$ & 0.85 & 204 & 13.5 \\
\hline $\mathrm{Cl}$ & $<0.25$ & 1.7 & $<0.25$ \\
\hline $\mathrm{F}$ & $<0.1$ & 0.2 & $<0.1$ \\
\hline $\mathrm{Al}$ & 0.77 & 7.7 & 0.34 \\
\hline $\mathrm{Fe}$ & $<20$ & 61 & $<20$ \\
\hline $\mathrm{Mn}$ & 0.1 & 29 & 0.6 \\
\hline $\mathrm{Cu}$ & $<0.5$ & 0.7 & $<0.5$ \\
\hline $\mathrm{Zn}$ & $<0.5$ & 4.7 & 0.6 \\
\hline $\mathrm{Pb}$ & $<0.05$ & $<0.05$ & $<0.05$ \\
\hline Mo & $<0.25$ & 1.5 & 0.41 \\
\hline $\mathrm{Sb}$ & $<0.01$ & 0.2 & $<0.1$ \\
\hline As & $<3$ & $<3$ & $<3$ \\
\hline Th & $<0.005$ & 0.02 & 0.01 \\
\hline $\mathrm{U}$ & $<0.001$ & 1.2 & 0.56 \\
\hline $\mathrm{Li}$ & 0.6 & 15 & 2.1 \\
\hline $\mathrm{Ba}$ & 54 & 264 & 88.5 \\
\hline $\mathrm{Sr}$ & 26 & 107 & 107 \\
\hline $\mathrm{V}$ & 0.7 & 1.8 & 0.9 \\
\hline $\mathrm{Sc}$ & 0.6 & 1.3 & 0.9 \\
\hline $\mathrm{Rb}$ & 0.5 & 3.1 & 0.47 \\
\hline $\mathrm{Y}$ & $<0.01$ & 0.1 & 0.03 \\
\hline $\mathrm{Zr}$ & $<0.05$ & $<0.05$ & $<0.05$ \\
\hline $\mathrm{La}$ & $<0.01$ & 0.02 & $<0.01$ \\
\hline
\end{tabular}

${ }^{1}$ Conductivity in $\mu \mathrm{S} / \mathrm{cm}$; $\mathrm{Ca}, \mathrm{Mg}, \mathrm{Na}, \mathrm{K}, \mathrm{SiO}_{2}, \mathrm{SO}_{4}, \mathrm{Cl}$, and $\mathrm{F}$ in $\mathrm{mg} / \mathrm{L}$; alkalinity in $\mathrm{mg} / \mathrm{L} \mathrm{HCO}_{3}{ }^{-}$; remaining elements in $\mu \mathrm{g} / \mathrm{L}$

${ }^{2} \mathrm{All}$ variables are geometric means except for $\mathrm{pH}$, which is arithmetic mean

$\mathrm{mg} / \mathrm{L}$, with a mean of $13.5 \mathrm{mg} / \mathrm{L}$. At seven sites sulfate concentrations were $>30 \mathrm{mg} / \mathrm{L}$, and at two sites they were $>100 \mathrm{mg} / \mathrm{L}$ (app. 1). The high sulfate concentrations probably are due to dissolution of gypsum that is present in the Permian and Pennsylvanian rocks. The Eagle Valley Evaporite and the Eagle Valley Formation north of Gunnison National Forest contain gypsum, and intertongue with the Minturn and Belden Formations and the lower part of the Maroon Formation (Tweto, 1976). The samples with sulfate concentrations of $>100 \mathrm{mg} / \mathrm{L}$ are from drainages underlain by the Maroon Formation and the Minturn and Belden Formations. The mean concentrations of trace elements $\mathrm{Zn}, \mathrm{Cu}$, Mo, and As are low, at $0.6,<0.5,<0.41$, and $<3$ $\mu \mathrm{g} / \mathrm{L}$, respectively. The mean concentrations of $\mathrm{Al}, \mathrm{Fe}$, and $\mathrm{Mn}$ are low, at $0.34,<20$, and $0.6 \mu \mathrm{g} / \mathrm{L}$, respectively. The alkalinity values are moderately high; they range from 110 to $194 \mathrm{mg} / \mathrm{L}$ as $\mathrm{HCO}_{3}{ }^{-}$, with a mean of $143 \mathrm{mg} / \mathrm{L}$. The moderately high alkalinity values probably are a result of the presence of abundant carbonate rocks and the carbonate cement in some of the clastic rocks. The moderately high alkalinity ensures that water in this area has a good capacity to neutralize effects from introduced acidification. The waters are moderately high in total dissolved solids; otherwise they are of good chemical quality.

\section{Tertiary and Proterozoic Intrusive Rocks and Proterozoic Metamorphic Rocks}

Water samples were collected from seven streams and one spring along the west flank of the Sawatch Range, in the Quartz Creek area (fig. 15) and Tomichi Creek area (fig. 16) in the Gunnison National Forest. The ranges and means of selected chemical species in water samples are listed in table 13. The areas are underlain by Proterozoic granite, granodiorite, quartz monzonite, diorites, gneiss, and gabbro, and by Tertiary granodiorite, quartz monzonite, and granite. The Proterozoic rocks are a basement complex, mainly metamorphic gneiss that was intruded by granite. The rocks are mostly felsic in composition, and here all are grouped as one rock type. The areas are of high relief, and annual rainfall ranges from 16 to $35 \mathrm{in}$. (Colorado Climate Center, 1984). The vegetation is mainly subalpine forest. The samples all are dilute $\mathrm{Ca}^{2+}-\mathrm{HCO}_{3}{ }^{-}$type water with slightly acidic to alkaline $\mathrm{pH}$ values. The $\mathrm{pH}$ values range from 6.89 to 8.18 , with a mean of 7.82 . The conductivity values are low; they range from 47 to $126 \mu \mathrm{S} / \mathrm{cm}$, with a mean of $83 \mu \mathrm{S} /$ $\mathrm{cm}$. The mean $\mathrm{Cl}$ concentration is $0.39 \mathrm{mg} / \mathrm{L}$. This indicates that the water, which contains significant snow melt, is in shortduration contact with the rocks, as is expected in areas underlain by dominantly crystalline rocks and characterized by poorly developed soil zones and poor reserves of ground water. In addition, the mainly felsic rock composition ensures that chemical weathering is slow. The mean $\mathrm{SiO}_{2}$ concentration is $14 \mathrm{mg} /$ $\mathrm{L}$, and it is about average for fresh water (table 3 ). Sulfate concentrations range from 1 to $15 \mathrm{mg} / \mathrm{L}$, with a mean of $3.5 \mathrm{mg} / \mathrm{L}$. The higher sulfate values of some samples (app. 1) probably are a result of oxidation of pyrite that is present in some of the rocks. Abandoned mines are present in the area, but disturbance in the sampled watersheds is insignificant. The mean concentrations of $\mathrm{Cu}$ and As are low, at $<1$ and $<0.03 \mu \mathrm{g} / \mathrm{L}$, respectively. The mean concentrations of $\mathrm{Zn}, \mathrm{Mo}$, and $\mathrm{U}$, at $0.64,0.83$, and $0.78 \mu \mathrm{g} / \mathrm{L}$, respectively, are slightly elevated compared to those in water from areas underlain by other rock types in this study. This probably is due to the presence of minor pyrite present in rocks in some of the watersheds. The mean concentrations of $\mathrm{Al}, \mathrm{Fe}$, and $\mathrm{Mn}$ are low, at 14,13 , and $0.3 \mu \mathrm{g} / \mathrm{L}$, respectively. The alkalinity values range from 20 to $50 \mathrm{mg} / \mathrm{L}$ as $\mathrm{HCO}_{3}{ }^{-}$, with a mean of $34 \mathrm{mg} / \mathrm{L}$. The low mean alkalinity indicates that the water in areas underlain by these rocks has a low capacity to neutralize introduced acidity. Therefore, the area is moderately susceptible to introduced acidification. The chemical quality of the waters is excellent. 


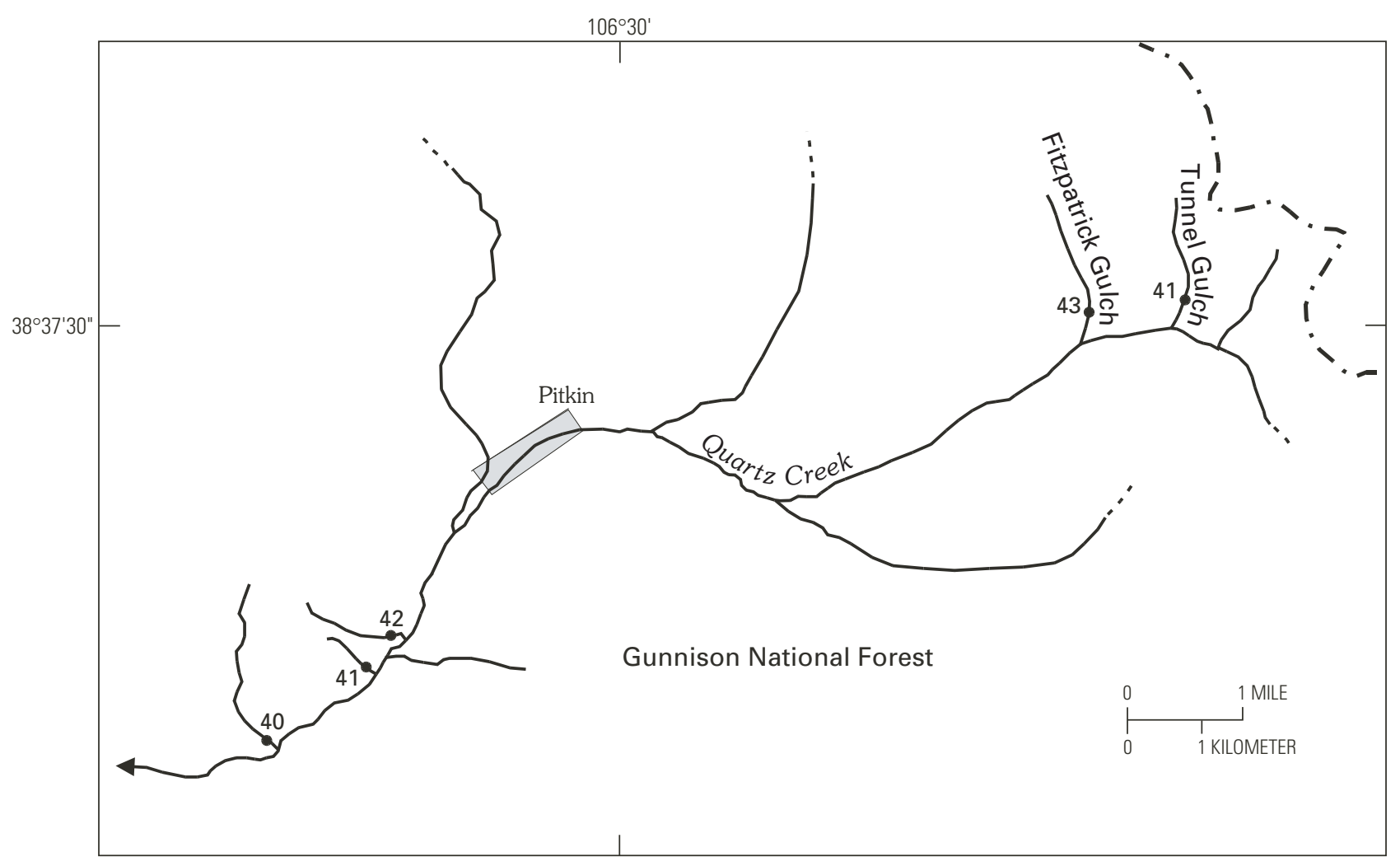

Figure 15. Site localities of stream water samples from areas underlain by Tertiary and Proterozoic intrusive rocks and Proterozoic metamorphic rocks in the Quartz Creek area, Gunnison National Forest, Colorado.

\section{Comparison of the Chemistry of Water Samples from Areas Underlain by the Ten Rock Types}

The chemistry of water in mountainous headwater areas depends on the chemical composition of the underlying bedrock. A unique range of water chemistry is associated with each rock type. For the ten rock composition types in this study, the means of selected chemical species and other parameters are listed in table 14.

The value of total dissolved solids (TDS) can be used to compute the rates at which rivers transport chemical weathering products to the ocean and can be used to calculate rates of chemical weathering. The TDS values also can be used to compare waters from different geologic terrains, as a means of comparing chemical weathering rates. A TDS value is the total amount of solids $(\mathrm{mg} / \mathrm{L})$ remaining when a water sample is evaporated. In calculations on the basis of analytical chemical data, a TDS value is the sum of all of the dissolved constituents, with bicarbonate converted to equivalent carbonate in the solid phase. This assumes that half of the bicarbonate is volatilized (Hem, 1992). The TDS value calculated for the water sample from each site is listed in appendix 1 . The mean TDS values for water samples from the ten rock types are listed in table 14. Water with the highest mean TDS values is in areas underlain by Mesozoic sedimentary rocks; next highest values are in areas underlain by Tertiary sedimentary rocks. Type and amounts of dissolved solids in the water are related primarily to the rock composition types, but also to the duration of contact of the water and the rocks and also to evaporation effects.

One way to minimize the duration of contact and the evaporation effects is to normalize TDS values by dividing The TDS value by the $\mathrm{Cl}$ content. This assumes that the $\mathrm{Cl}$ content is conservative and does not readily react with other ions and precipitate and that there was no addition of $\mathrm{Cl}$ to the water by dissolution of minerals (such as halite) containing $\mathrm{Cl}$. This normalization is done for the samples at each site, and the mean then is calculated for all the sites for a specific rock type to obtain a mean TDS/Cl value for that rock composition type. The highest normalized TDS values are from areas underlain by Paleozoic sedimentary rocks. The next highest values are from areas underlain by Mancos Shale, Tertiary sedimentary rocks, and Mesaverde Formation (table 15). The lowest normalized TDS values are from areas underlain by Mesozoic sedimentary rocks and Tertiary ash-flow tuff.

Chemical weathering rates are dependent on the amount of atmospheric precipitation; the greater the precipitation, the higher the chemical weathering rate. By normalizing TDS values, precipitation dependency is eliminated and the normalized TDS values reflect potential chemical weathering. The actual weathering rate is dependent on amounts of precipitation. Another way to look at potential weathering rate is that this would be the rate if all the rock types received the same amounts of precipitation.

Paleozoic sedimentary rocks are undergoing the most rapid potential rate of chemical weathering. Gypsum in the Paleozoic 


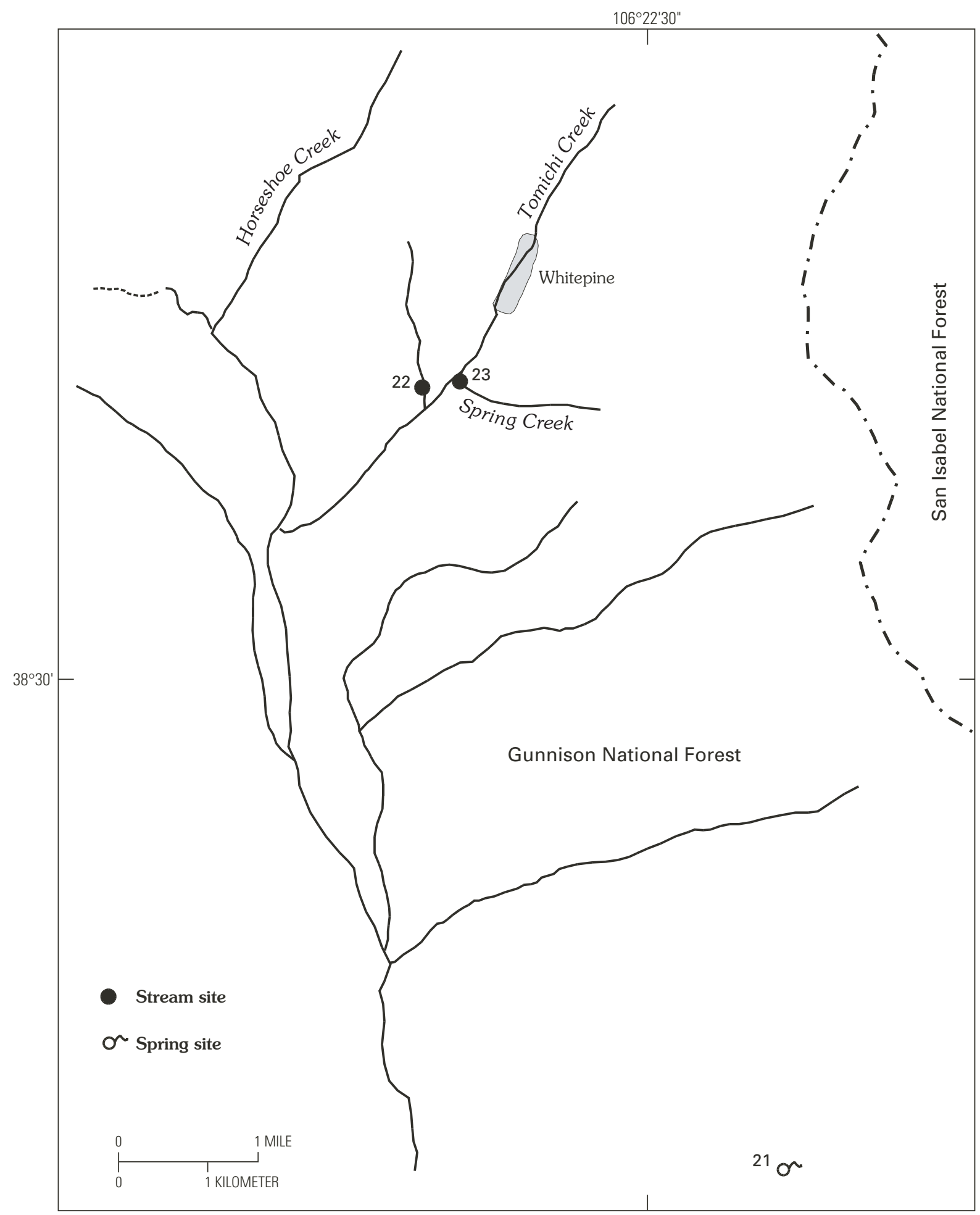

Figure 16. Site localities of stream and spring water samples from areas underlain by Proterozoic intrusive and metamorphic rocks along the western flank of the Sawatch Range, Gunnison National Forest, Colorado.

sedimentary rocks probably is a major contributor to the TDS of water in areas underlain by these rocks. The Mesozoic sedimentary rocks and the Tertiary ash-flow tuff are undergoing the slowest potential rate of chemical weathering, and they are supplying the lowest amounts of dissolved solids to the water. The Mesozoic sedimentary rocks contain abundant, wellcrystallized silica minerals that are resistant to weathering. The felsic Tertiary ash-flow tuff is more resistant to weathering than are more mafic rocks.

Maps were constructed showing the potential release of TDS, as normalized TDS values that are recalculated so that all values were between 0 and 1 . The highest mean normalized TDS value (table 15) is from Paleozoic sedimentary rocks, and it therefore was assigned a value of one. The recalculated mean 
Table 13. Summary of the chemistry of seven stream water samples and one spring water sample from areas underlain by Tertiary and Proterozoic intrusive rocks and Proterozoic metamorphic rocks, Gunnison National Forest, Colorado.

\begin{tabular}{|c|c|c|c|}
\hline \multirow[t]{2}{*}{ Measurement ${ }^{1}$} & \multicolumn{2}{|c|}{ Range } & \multirow[t]{2}{*}{ Mean ${ }^{2}$} \\
\hline & Minimum & Maximum & \\
\hline Conductivity & 47 & 126 & 83 \\
\hline $\mathrm{pH}$ & 6.89 & 8.18 & 7.82 \\
\hline $\mathrm{Ca}$ & 5.8 & 12 & 8 \\
\hline $\mathrm{Mg}$ & 0.51 & 4.1 & 1.7 \\
\hline $\mathrm{Na}$ & 1.2 & 5.3 & 3.1 \\
\hline $\mathrm{K}$ & 0.24 & 0.84 & 0.55 \\
\hline $\mathrm{SiO}_{2}$ & 6.1 & 22 & 14 \\
\hline Alkalinity & 20 & 50 & 34 \\
\hline $\mathrm{SO}_{4}$ & 11 & 5 & 3.5 \\
\hline $\mathrm{Cl}$ & $<0.25$ & 0.9 & 0.39 \\
\hline $\mathrm{F}$ & $<0.1$ & 2.2 & 0.21 \\
\hline $\mathrm{Al}$ & 5.1 & 47 & 14 \\
\hline $\mathrm{Fe}$ & $<5$ & 35 & 13 \\
\hline Mn & $<0.3$ & 0.49 & $<0.3$ \\
\hline $\mathrm{Cu}$ & $<1$ & 1 & $<1$ \\
\hline $\mathrm{Zn}$ & 0.22 & 5.1 & 0.64 \\
\hline $\mathrm{Pb}$ & $<0.1$ & 1.3 & 0.2 \\
\hline Mo & $<0.5$ & 2.9 & 0.83 \\
\hline $\mathrm{Sb}$ & $<0.01$ & 0.15 & 0.015 \\
\hline As & $<0.03$ & $<0.03$ & $<0.03$ \\
\hline Th & 0.023 & 0.37 & 0.077 \\
\hline $\mathrm{U}$ & 0.17 & 7.3 & 0.78 \\
\hline $\mathrm{Li}$ & 0.68 & 5.7 & 1.7 \\
\hline $\mathrm{Ba}$ & 2.6 & 29 & 8.7 \\
\hline $\mathrm{Sr}$ & 28 & 48 & 37 \\
\hline $\mathrm{V}$ & $<0.5$ & 0.57 & $<0.5$ \\
\hline $\mathrm{Sc}$ & $<10$ & 30 & 20 \\
\hline $\mathrm{Rb}$ & 0.12 & 1.5 & 0.35 \\
\hline $\mathrm{Y}$ & $<0.3$ & 0.77 & 0.17 \\
\hline $\mathrm{Zr}$ & 0.084 & 12.5 & 0.35 \\
\hline $\mathrm{La}$ & $<0.005$ & 0.57 & 0.036 \\
\hline $\mathrm{Br}$ & $<3$ & $<3$ & $<3$ \\
\hline I & $<0.2$ & 3.2 & 0.22 \\
\hline
\end{tabular}

${ }^{1}$ Conductivity in $\mu \mathrm{S} / \mathrm{cm}$; $\mathrm{Ca}, \mathrm{Mg}, \mathrm{Na}, \mathrm{K}, \mathrm{SiO}_{2}, \mathrm{SO}_{4}, \mathrm{Cl}$, and $\mathrm{F}$ in $\mathrm{mg} / \mathrm{L}$; alkalinity in $\mathrm{mg} / \mathrm{L} \mathrm{HCO}_{3}{ }^{-}$; remaining elements in $\mu \mathrm{g} / \mathrm{L}$

${ }^{2} \mathrm{All}$ variables are geometric means except for $\mathrm{pH}$, which is arithmetic mean

normalized TDS values for the other rock composition types were calculated by dividing the mean normalized TDS value for that rock type by the highest mean normalized TDS value.

Ranks of the potential release of TDS are listed in table 16. Maps showing the potential release of TDS were constructed for each of the three national forests, by plotting the recalculated mean normalized TDS values from table 16 in relation to the rock composition types. The maps of potential release of TDS for the three national forests are figures 17-19.

The mean values for $\mathrm{pH}$ of water from areas underlain by the ten rock composition types range from 7.41 , for Tertiary basaltic rocks, to 8.50 for Tertiary sedimentary rocks. The $\mathrm{pH}$ values in these headwater streams are affected by the amount of snow and storm runoff as a component of the total flow, and by the duration of contact of water and rock. Because the $\mathrm{pH}$ of atmospheric precipitation is buffered by $\mathrm{CO}_{2}$ to approximately 5.7 (Carroll, 1962), snow and storm runoff generally lower the $\mathrm{pH}$. The $\mathrm{pH}$ of water in contact with rock minerals such as silicates and carbonates generally increases with duration of contact of the water and rock. Because the $\mathrm{pH}$ values of the water samples are important for assessment of acidity of the watersheds, maps were made showing the mean $\mathrm{pH}$. The mean $\mathrm{pH}$ values were plotted in relation to each of the rock composition types for each of the three national forests (figs. 20-22).

The alkalinity of a solution is the capacity for solutes it contains to react with and neutralize acid (Hem, 1992). Alkalinity is determined by titration with a strong acid. Several different chemical species may contribute to alkalinity. However, for almost all natural fresh water, the alkalinity is produced by the dissolved carbon dioxide species bicarbonate and carbonate (Hem, 1992). In this study alkalinity is reported as equivalent amounts of bicarbonate. If an area is affected by acid mine drainage or acid rain, the alkalinity will react with and consume the introduced acid until all the alkalinity is used up. After this, if acid is still introduced, the acidity of the water increases.

Therefore, the alkalinity is a measure of the capacity of a watershed to resist the introduction of acid. The higher the alkalinity value, the greater the capacity of the water to neutralize and consume acid.

The mean alkalinity values of water from areas underlain by the ten rock types range from 28 to $205 \mathrm{mg} / \mathrm{L}$ as $\mathrm{HCO}_{3}{ }^{-}$. The water samples with the highest alkalinity values are from areas underlain by Mesozoic sedimentary rocks and the samples with the lowest alkalinity values are from areas underlain by Tertiary basaltic rocks (table 14). Alkalinity depends primarily on the rock composition type, but it also is related to the duration of contact of the rocks and water and to evaporation effects. To decrease the effect of the duration of contact and effects of evaporation, alkalinity is normalized using the $\mathrm{Cl}$ content, in a manner similar to the procedure used to normalize TDS. This assumes that the $\mathrm{Cl}$ content is conservative, and that there is no addition of dissolved solids to the water by dissolution of soluble salts containing $\mathrm{Cl}$. Note that this procedure is carried out for the sample from each site, and then the mean is calculated for all of the samples associated with a specific rock type, to obtain the mean alkalinity/Cl value. The highest mean normalized alkalinity value is from areas underlain by Paleozoic sedimentary rocks, followed by areas underlain by the Mancos Shale and Tertiary sedimentary rocks (table 15). The lowest mean normalized alkalinity value is from areas underlain by Tertiary ash flow tuff. The normalized alkalinity value is a measure of the ability of the watershed to neutralize introduced acidity.

Maps showing acid-neutralizing capacity were constructed by recalculating the mean normalized alkalinity values in a manner similar to the procedure for normalization of TDS values, so that all values were between 0 and 1 . The highest mean normalized alkalinity value, of water from areas underlain by Paleozoic sedimentary rocks, was assigned a value of one. The recalculated mean normalized alkalinity values water associated 
Table 14 Summary of the chemical analyses and other parameters of water samples from areas underlain by various rock composition types, Grand Mesa, Uncompahgre, and Gunnison National Forests, Colorado.

[Complete data shown in app.

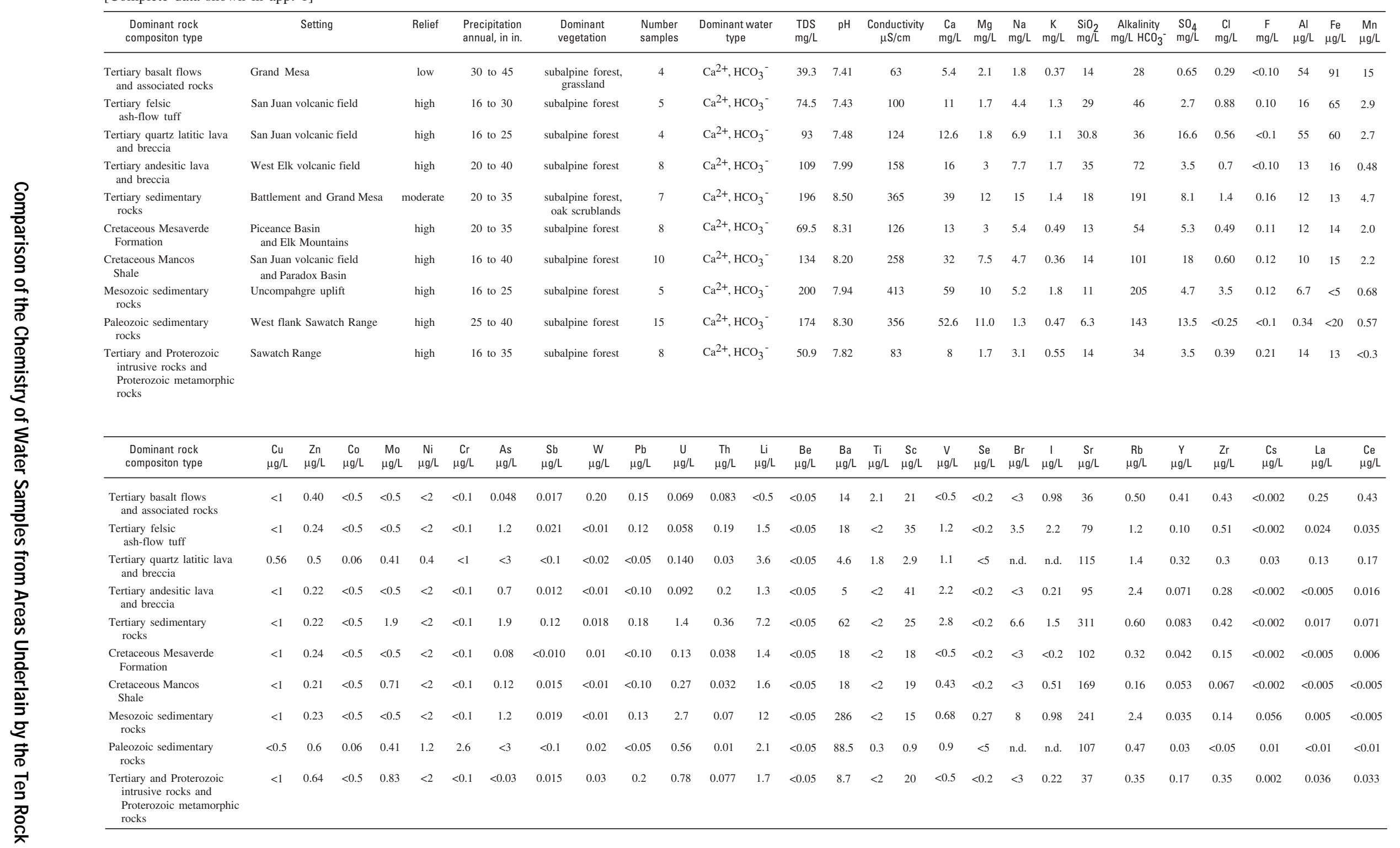


Table 15 Mean normalized values for selected parameters and species for water samples from Grand Mesa, Uncompahgre, and Gunnison National Forests and the Redcloud Peak area, Colorado.

[Complete data shown in app. 1,2]

\begin{tabular}{|c|c|c|c|c|c|c|c|c|c|c|c|c|c|}
\hline & $\begin{array}{l}\text { Mean } \\
\text { Chloride }\end{array}$ & $\begin{array}{l}\text { Mean } \\
\text { TDS }\end{array}$ & $\begin{array}{l}\text { Mean } \\
\text { TDS/Cl }\end{array}$ & $\begin{array}{l}\text { Mean } \\
\text { Alkalinity }\end{array}$ & $\begin{array}{c}\text { Mean } \\
\text { Alkalinity/Cl }\end{array}$ & $\begin{array}{l}\text { Mean } \\
\text { Sulfate }\end{array}$ & $\begin{array}{c}\text { Mean } \\
\text { Sulfate/Cl }\end{array}$ & $\begin{array}{l}\text { Mean } \\
\quad F\end{array}$ & $\begin{array}{l}\text { Mean } \\
\mathrm{F} / \mathrm{Cl}\end{array}$ & $\begin{array}{l}\text { Mean } \\
\mathrm{U}\end{array}$ & $\begin{array}{c}\text { Mean } \\
\mathrm{U} / \mathrm{Cl}\end{array}$ & $\begin{array}{l}\text { Mean } \\
\mathrm{Li}\end{array}$ & $\begin{array}{l}\text { Mean } \\
\mathrm{Li} / \mathrm{Cl}\end{array}$ \\
\hline \multicolumn{14}{|c|}{ GMUG Area } \\
\hline Tertiary basalt flows and associated rock & 0.29 & 39.3 & 134 & 28 & 97 & 0.65 & 2.24 & 0.07 & 0.24 & 0.069 & 0.24 & 0.3 & 1.03 \\
\hline Tertiary felsic ash-flow tuff & 0.88 & 74.5 & 84.7 & 46 & 52 & 2.7 & 3.07 & 0.1 & 0.11 & 0.058 & 0.07 & 1.5 & 1.7 \\
\hline Tertiary quartz latitic lava and breccia & 0.56 & 93 & 166 & 36 & 64 & 16.6 & 30 & $<0.1$ & 0.125 & 0.14 & 0.25 & 3.6 & 6.4 \\
\hline Tertiary andesitic lava and breccia & 0.65 & 109 & 156 & 72 & 103 & 3.5 & 5 & 0.07 & 0.1 & 0.092 & 0.13 & 1.3 & 1.86 \\
\hline Tertiary sedimentary rocks & 1.4 & 196 & 145 & 191 & 136 & 8.1 & 5.79 & 0.16 & 0.11 & 1.4 & 1 & 7.2 & 5.14 \\
\hline Cretaceous Mesaverde Formation & 0.49 & 69.5 & 142 & 54 & 110 & 5.3 & 10.8 & 0.11 & 0.22 & 0.13 & 0.27 & 1.4 & 2.86 \\
\hline Cretaceous Mancos Shale & 0.6 & 134 & 222 & 101 & 168 & 18 & 30 & 0.12 & 0.2 & 0.27 & 0.45 & 1.6 & 2.67 \\
\hline Mesozoic sedimentary rocks & 3.4 & 200 & 58.1 & 205 & 59 & 4.7 & 1.34 & 0.12 & 0.03 & 2.7 & 0.77 & 12 & 3.43 \\
\hline Paleozoic sedimentary rocks & $<0.25$ & 174 & 715 & 143 & 572 & 13.5 & 54 & $<0.1$ & 0.28 & 0.56 & 2.24 & 2.1 & 8.4 \\
\hline $\begin{array}{l}\text { Tertiary and Proterozoic intrusive and } \\
\text { Proterozoic metamorphic rocks }\end{array}$ & 0.39 & 50.9 & 132 & 34 & 87 & 3.5 & 8.97 & 0.21 & 0.54 & 0.78 & 2 & 1.7 & 4.36 \\
\hline
\end{tabular}

\begin{tabular}{|c|c|c|c|c|c|c|c|c|c|c|c|c|}
\hline Sunshine Peak Tuff & 0.12 & 66.4 & 552 & 3.9 & 33 & 30 & 252 & 0.17 & 1.41 & 0.66 & 5.49 & 3.7 \\
\hline
\end{tabular}

Total dissolved solids (TDS) in mg/L; chloride, sulfate, and fluoride in $\mathrm{mg} / \mathrm{L}$; alkalinity in $\mathrm{mg} / \mathrm{L} \mathrm{HCO}_{3}{ }^{-}$; remaining elements in $\mu \mathrm{g} / \mathrm{L}$; TDS/Cl, $\mathrm{Alkalinity} / \mathrm{Cl}, \mathrm{F} / \mathrm{Cl}, \mathrm{U} / \mathrm{Cl}$ and $\mathrm{Li} / \mathrm{Cl}$ are unitless. 


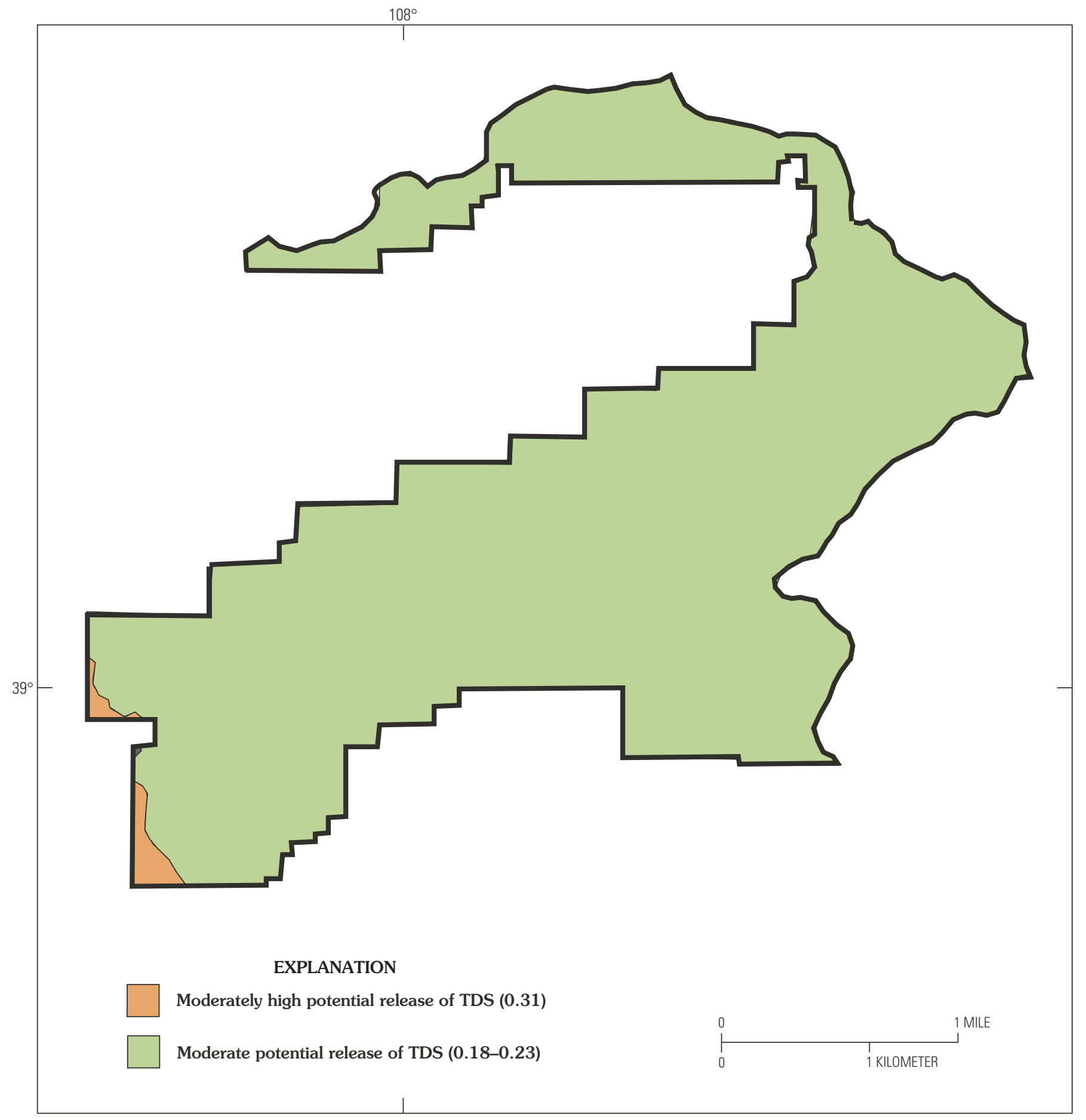

Figure 17. Potential release of total dissolved solids (TDS) in stream and spring waters in the Grand Mesa National Forest, Colorado.

with other rock composition types were calculated by dividing the mean normalized alkalinity value of the specific rock type by the highest mean normalized alkalinity value. The ranks of acid-neutralizing capacities to introduced acidity are listed in table 16. Maps showing acid-neutralizing capacities to introduced acidity for each of the three national forests were constructed by plotting the recalculated mean normalized alkalinity values from table 16 in relation to the rock composition types. The maps of the three national forests are figs. 23-25.
The mean concentrations of silica in water from areas underlain by the ten composition rock types range from $11 \mathrm{mg} /$ $\mathrm{L}$, for Mesozoic sedimentary rocks, to $35 \mathrm{mg} / \mathrm{L}$, for Tertiary andesitic rocks (table 14). Other high mean silica concentrations are from areas underlain by Tertiary quartz latitic lava and breccia $(31 \mathrm{mg} / \mathrm{L})$ and ash flow tuff $(29 \mathrm{mg} / \mathrm{L})$. The high mean silica values probably are related to the fact that these rocks contain fine-grained silicate minerals with large surface areas, and therefore they are particularly susceptible to dissolution of 
Table 16. Ranking of rock composition types with respect to potential release of total dissolved solids (TDS) and neutralizing capacity to introduced acidity in the Grand Mesa, Uncompahgre, and Gunnison National Forests, Colorado.

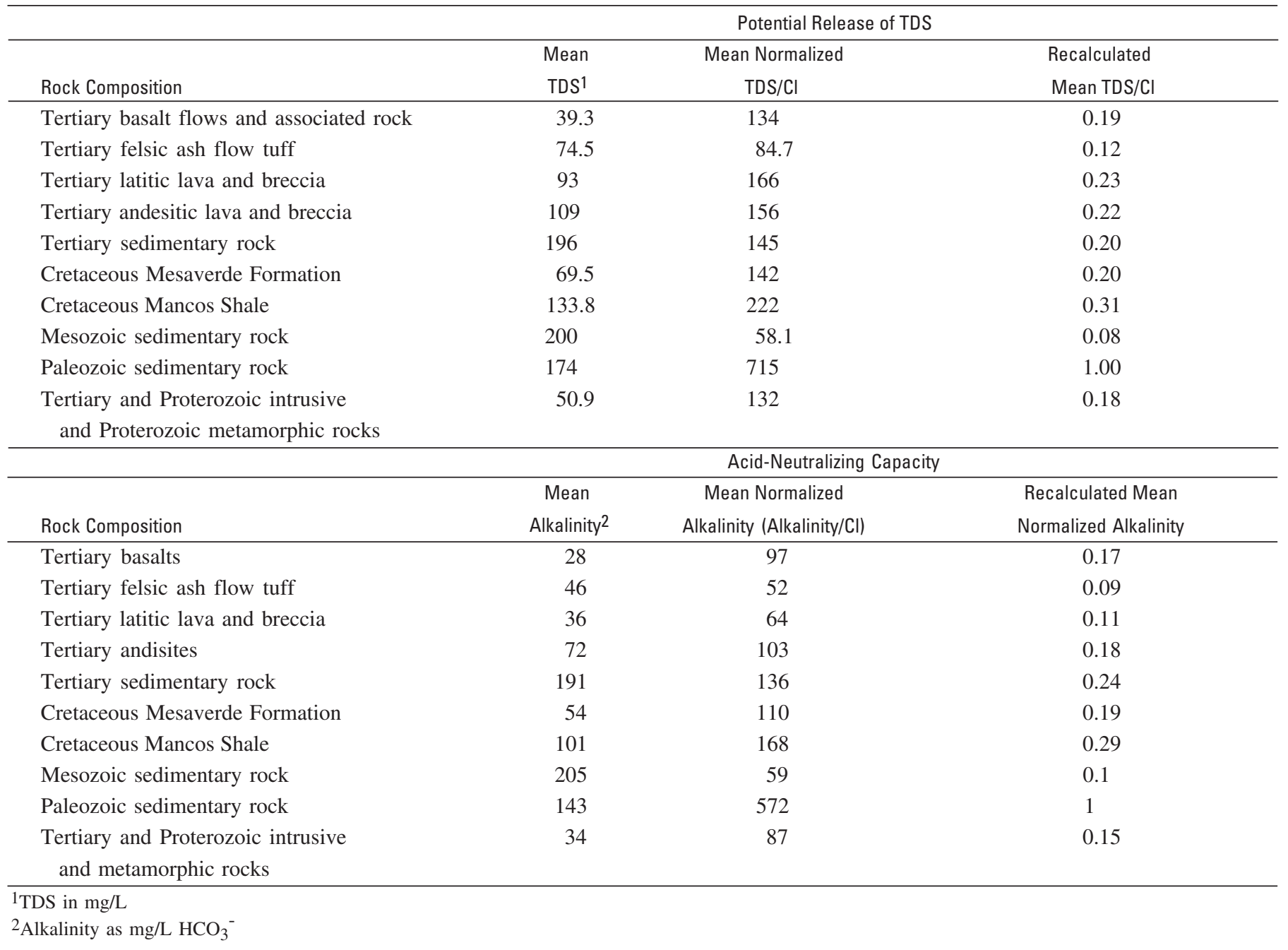

silica. Conversely, the Mesozoic sedimentary rocks contain sandstone that is composed of large-sized and well-crystallized mineral grains that have smaller surface areas. The latter grains are more resistant to silica dissolution.

The mean concentrations of $\mathrm{Cu}, \mathrm{Zn}, \mathrm{Co}, \mathrm{Ni}, \mathrm{Cr}, \mathrm{Sb}, \mathrm{Pb}$, and $\mathrm{Be}$ in water samples from watersheds underlain by the ten rock types all are low (table 14). In addition, the mean values for Se all are $<0.2 \mu \mathrm{g} / \mathrm{L}$, except for samples from areas underlain by Mesozoic sedimentary rocks, for which the mean is 0.27 $\mu \mathrm{g} / \mathrm{L}$. Thus, the contribution of Se in these mountainous headwater watersheds is very low. The Mancos Shale is a source of Se concentrations in water in the lower parts of valleys, particularly in areas of irrigation (Wright and Butler, 1993). In these mountainous headwater streams, in areas underlain by the Mancos Shale, evaporation effects are minimal and Se concentrations are low.

The mean concentrations of Mo are low, except for a slightly elevated mean value $(1.9 \mu \mathrm{g} / \mathrm{L})$ in water from areas underlain by Tertiary sedimentary rocks. The mean concentrations of $\mathrm{U}$ are low, except for slightly elevated mean values in water from areas underlain by Mesozoic sedimentary rocks (2.7 $\mu \mathrm{g} / \mathrm{L})$ and Tertiary sedimentary rocks $(1.4 \mu \mathrm{g} / \mathrm{L})$. The mean concentrations of As are low for water from the three national forests, except for slightly elevated mean values in water from areas underlain by Tertiary sedimentary rocks $(1.9 \mu \mathrm{g} / \mathrm{L})$, Tertiary ash-flow tuff $(1.2 \mu \mathrm{g} / \mathrm{L})$, and Mesozoic sedimentary rocks $(1.2 \mu \mathrm{g} / \mathrm{L})($ table 14$)$.

The mean values for $\mathrm{Al}$ of all rock types are low compared to average fresh water (table 3), except for elevated mean values $(54$ and $55 \mu \mathrm{g} / \mathrm{L})$ in water from areas underlain by Tertiary basalt and Tertiary quartz latitic lava and breccia. The mean values for Fe of all rock types are low, except for elevated mean values $(91,65$, and $60 \mu \mathrm{g} / \mathrm{L})$ in water from areas underlain by Tertiary basalt, Tertiary quartz latitic lava and breccia, and Tertiary ash flow tuff. The mean values for $\mathrm{Mn}$ of all rock types are low, except for elevated mean value $(15 \mu \mathrm{g} / \mathrm{L})$ in water from areas underlain Tertiary basalt (table 14).

Sulfate, F, and $\mathrm{U}$ are mobile as anion species in alkaline water. The degree to which these elements are concentrated in water depends on the duration of contact of the water and rock, and also on evaporation effects. The highest mean sulfate concentration $(18 \mathrm{mg} / \mathrm{L})$ is in water from areas underlain by the Mesaverde Formation (table 14). The Mesaverde Formation 


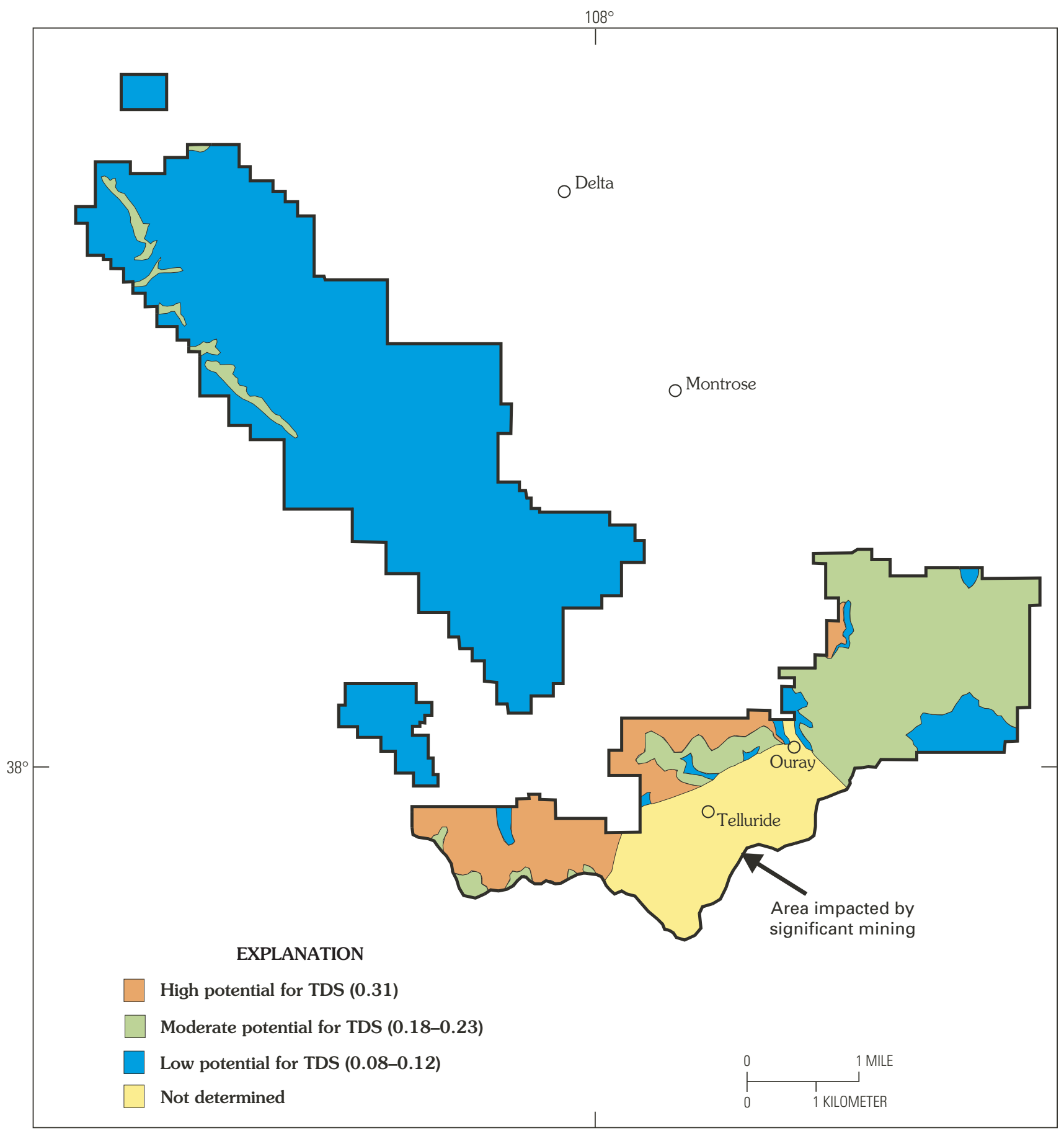

Figure 18. Potential release of total dissolved solids (TDS) in stream and spring waters in the Uncompahgre National Forest, Colorado.

contains coal with associated pyrite. Weathering of the pyrite probably is the source of the sulfate. To reduce the effects of evaporation and the duration of contact of water and rock, sulfate values were normalized by dividing the sulfate concentration by the $\mathrm{Cl}$ concentration for each sample, and the mean was calculated for all sites associated with a specific rock type to produce the mean sulfate/Cl value. The highest mean normalized values for sulfate are from water from areas underlain by Paleozoic sedimentary rocks and the Mancos Shale, followed by water from areas underlain by Tertiary sedimentary rocks and the Mesaverde Formation (table 15). This highest mean normalized sulfate value, from areas underlain by Paleozoic sedimentary rocks, probably is due to dissolution of gypsum in the rocks. The high values in water associated with other rock composition types probably are due to the weathering of pyrite in the sedimentary rocks.

The highest mean F concentration $(0.21 \mathrm{mg} / \mathrm{L})$ is in water from areas underlain by Tertiary and Proterozoic intrusive and Proterozoic metamorphic rocks (table 14). The high concentration of F probably is a result of the high F content of the Tertiary and Proterozoic intrusive and Proterozoic metamorphic rocks. When $\mathrm{F}$ is normalized in a manner similar to the procedure used 


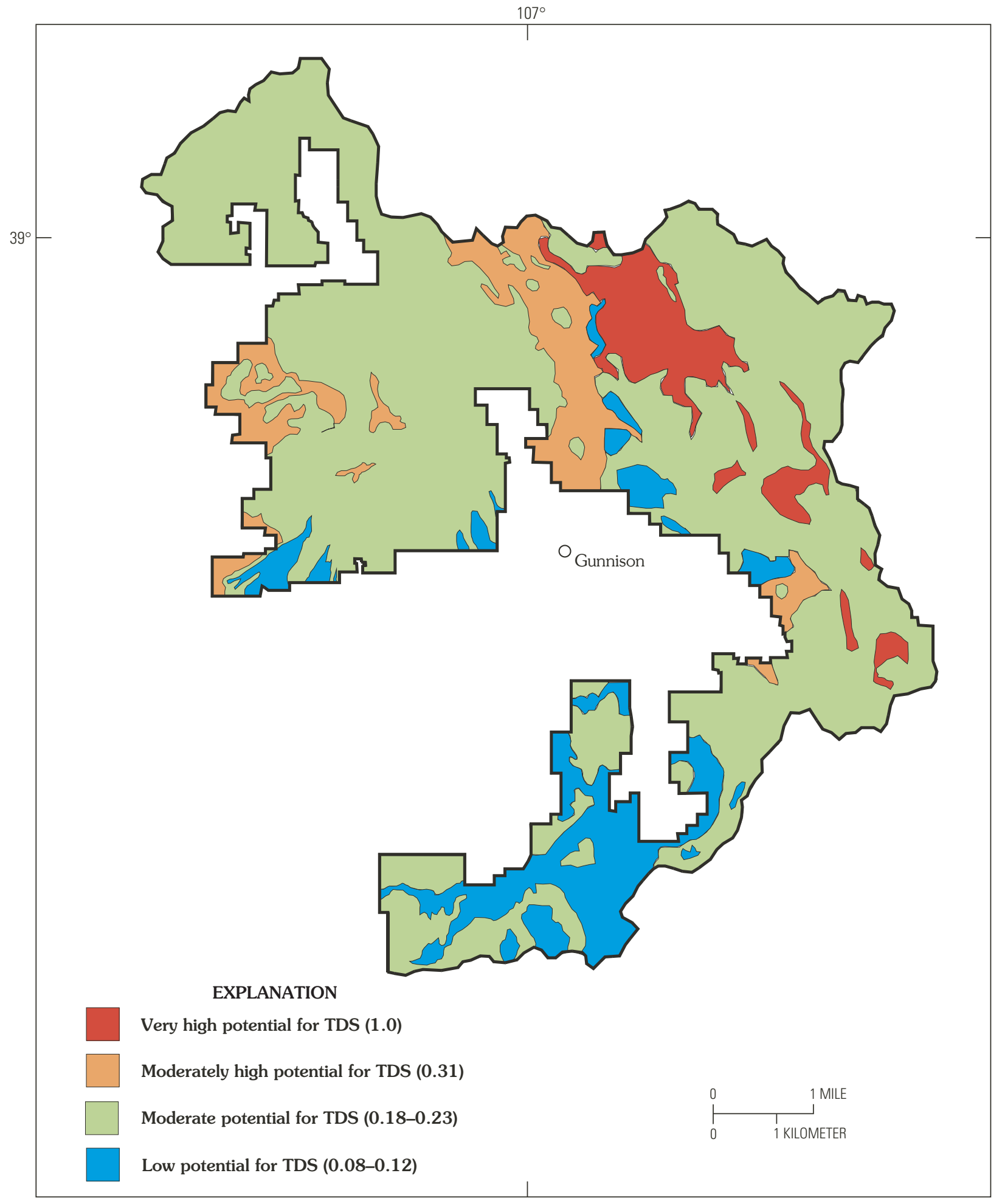

Figure 19. Potential release of total dissolved solids (TDS) in stream and spring waters in the Gunnison National Forest, Colorado.

to produce mean normalized values for sulfate, these rocks are even more anomalous, compared to the other major rock composition types (table 15). The Tertiary basaltic rocks are next highest in normalized $\mathrm{F}$, indicating that the basaltic rocks are elevated in $\mathrm{F}$.

The highest mean U concentrations (table 14) are in water from areas underlain by Mesozoic sedimentary rocks $(2.7 \mu \mathrm{g} /$ $\mathrm{L})$, Tertiary sedimentary rocks $(1.4 \mu \mathrm{g} / \mathrm{L})$, and Tertiary and
Proterozoic intrusive and Proterozoic metamorphic rocks ( 0.78 $\mu \mathrm{g} / \mathrm{L})$. When $\mathrm{U}$ is normalized, in a manner similar to the procedure used for sulfate, the highest values (table 15) are in water from areas underlain by Paleozoic sedimentary rocks (2.2), Tertiary and Proterozoic intrusive and Proterozoic metamorphic rocks (2.0), Tertiary sedimentary rocks (1.0), and Mesozoic sedimentary rocks $(0.77)$. These values indicate that these rock composition types are elevated in leachable $\mathrm{U}$. 


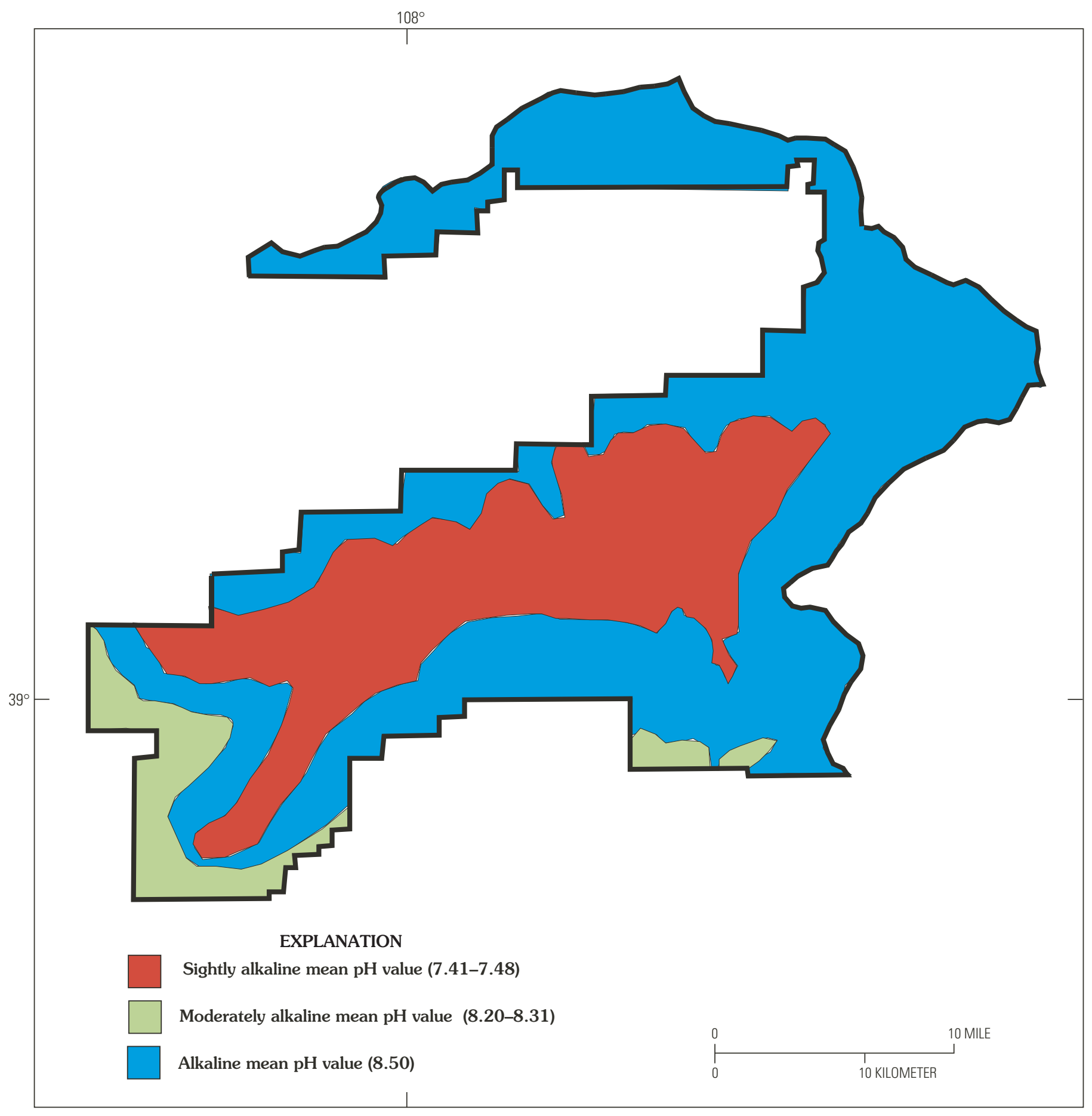

Figure 20. Mean pH values of stream and spring waters in the Grand Mesa National Forest, Colorado.

The highest mean $\mathrm{Li}$ value $(12 \mu \mathrm{g} / \mathrm{L})$ is in water from areas underlain by Mesozoic sedimentary rocks. This value is high, compared to values from samples associated with the other rock composition types (table 14). Much of the high mean Li concentration is the result of a longer duration of contact of water and rock and to the evaporation effects associated with the spring water. If $\mathrm{Li}$ is normalized in a manner similar to that described previously, the water samples with the highest mean normalized $\mathrm{Li}$ values are associated with Tertiary sedimentary rocks (5.14), followed by Tertiary and Proterozoic intrusive and
Proterozoic metamorphic rocks (4.36), and Mesozoic sedimentary rocks (3.43) (table 15).

To gain an understanding of processes such as chemical speciation of elements and the identification of the saturation state of minerals that possibly control the concentration, mobility, and attenuation of elements in the stream water, chemical modeling of the stream water was carried out using PHREEQC (Parkhurst, 1995). The modeling program assumes that there is mineral-solution equilibrium. For some chemical reactions, particularly with slow kinetics, this possibly is not the case. 


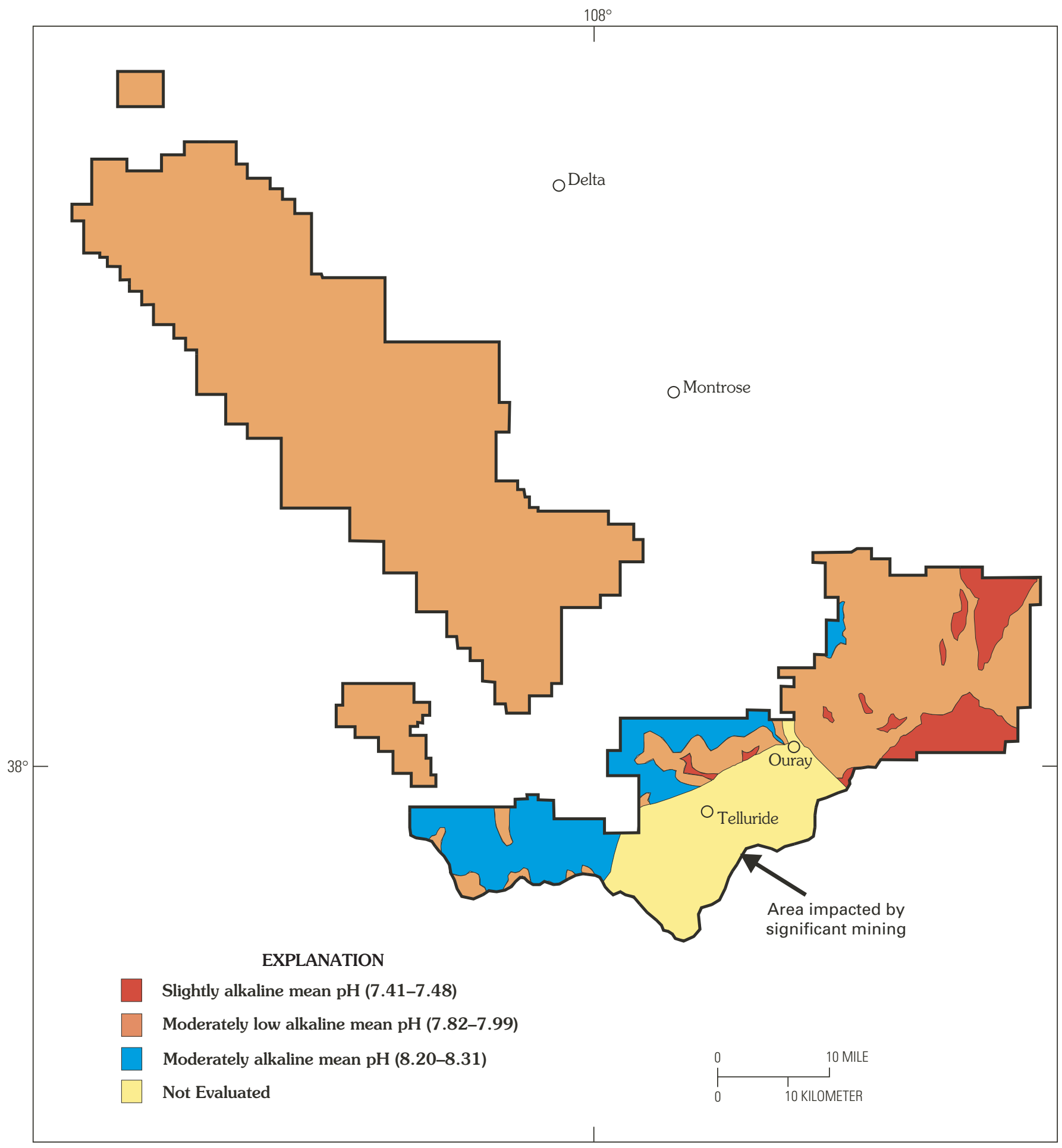

Figure 21. Mean pH values of stream and spring waters in the Uncompahgre National Forest, Colorado.

Except for $\mathrm{Al}$, the cations in the stream water samples are present mostly as simple cations, and the anions are present as chloride, sulfate, carbonate, and bicarbonate complexes (table 17). In addition, the state of saturation of the water with mineral phases was calculated. Saturation indices were calculated for a suite of minerals, to determine if concentrations of species in the water were controlled by mineral phases. The saturation index is a convenient way to express saturation states of minerals (Barnes and Clark, 1969) where:

$$
\mathrm{SI}=\log _{10} \mathrm{IAP} / \mathrm{K}_{\mathrm{T}}
$$

In the expression, $\mathrm{SI}$ is the saturation index, IAP is the ion activity product, and $\mathrm{K}_{\mathrm{T}}$ is the equilibrium constant of the dissolution reaction at the temperature of the sample. Mineral phases are supersaturated at $\mathrm{SI}>0$, saturated at $\mathrm{SI}=0$, and undersaturated at $\mathrm{SI}<0$.

The input for the modeling was the mean values for each rock composition type listed in table 14. The water from areas 


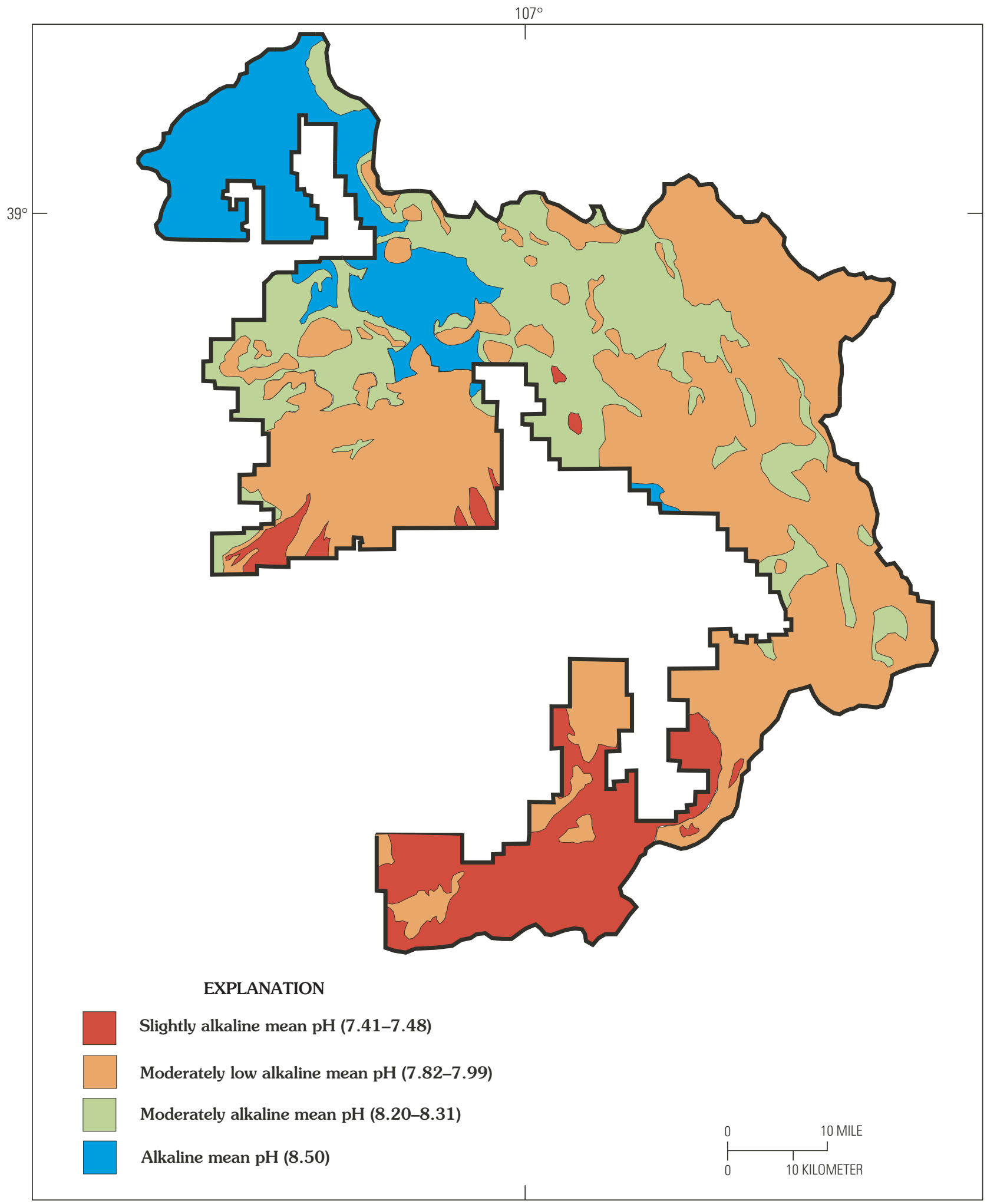

Figure 22. Mean pH values of stream and spring waters in the Gunnison National Forest, Colorado.

underlain by Tertiary sedimentary rocks, the Mancos Shale, Mesozoic sedimentary rocks, and Paleozoic sedimentary rocks is supersaturated with respect to calcite and dolomite (table 18). These are headwater streams, not streams in the lower parts of valleys where secondary calcite is abundant. Therefore, the water is in contact with dissolving carbonate minerals, such as calcite and dolomite that are present in the bedrock. Another mineral, which influences chemical species in water, is chalcedony. Most of the water associated with each of the rock composition types is saturated or slightly oversaturated with respect to chalcedony (table 18). Chalcedony appears to control the amount of dissolved silica in the water. Water associated with 


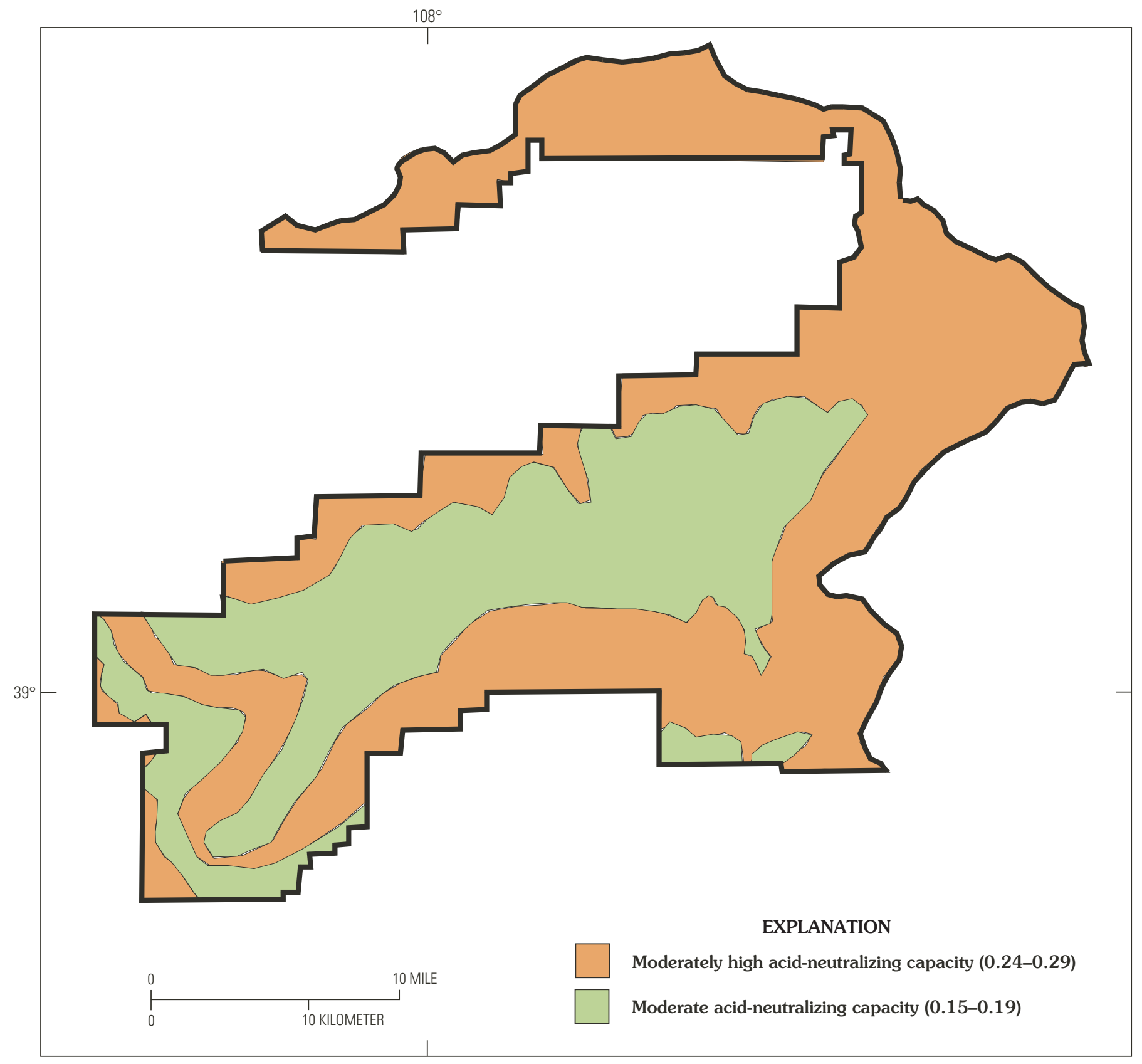

Figure 23. Acid-neutralizing capacity to introduced acidity in the Grand Mesa National Forest, Colorado.

Tertiary sedimentary rocks is oversaturated with respect to sepiolite (table 18). Sepiolite appears to control Mg mobility. Mg is probably the product of weathering of dolomite.

\section{Comparison of Water Samples from Areas Underlain by the Ten Rock Composition Types and Water Samples from an Area Underlain by Mineralized Rocks}

No significant mineralization has been identified in the watersheds sampled in the three National Forests. Significant mineralization is present in other watersheds in the three national forests, particularly in upper parts of the Uncompahgre and San Miguel River basins and in the Crested Butte area. Contamination from mining has altered the natural baselines of water in watersheds where mining has taken place; therefore, natural baselines for these areas cannot be determined directly.

The Redcloud Peak area near Lake City, Colo., is administered by the Bureau of Land Management (BLM) and is adjacent to the Gunnison and Uncompahgre National Forests. The area contains significant mineralization, but no large-scale mining has taken place. Water samples from streams in the Redcloud Peak area were collected in a previous study (Miller and McHugh, 1998). The water chemistry of this mineralized area here is compared to the water chemistry in areas underlain by 


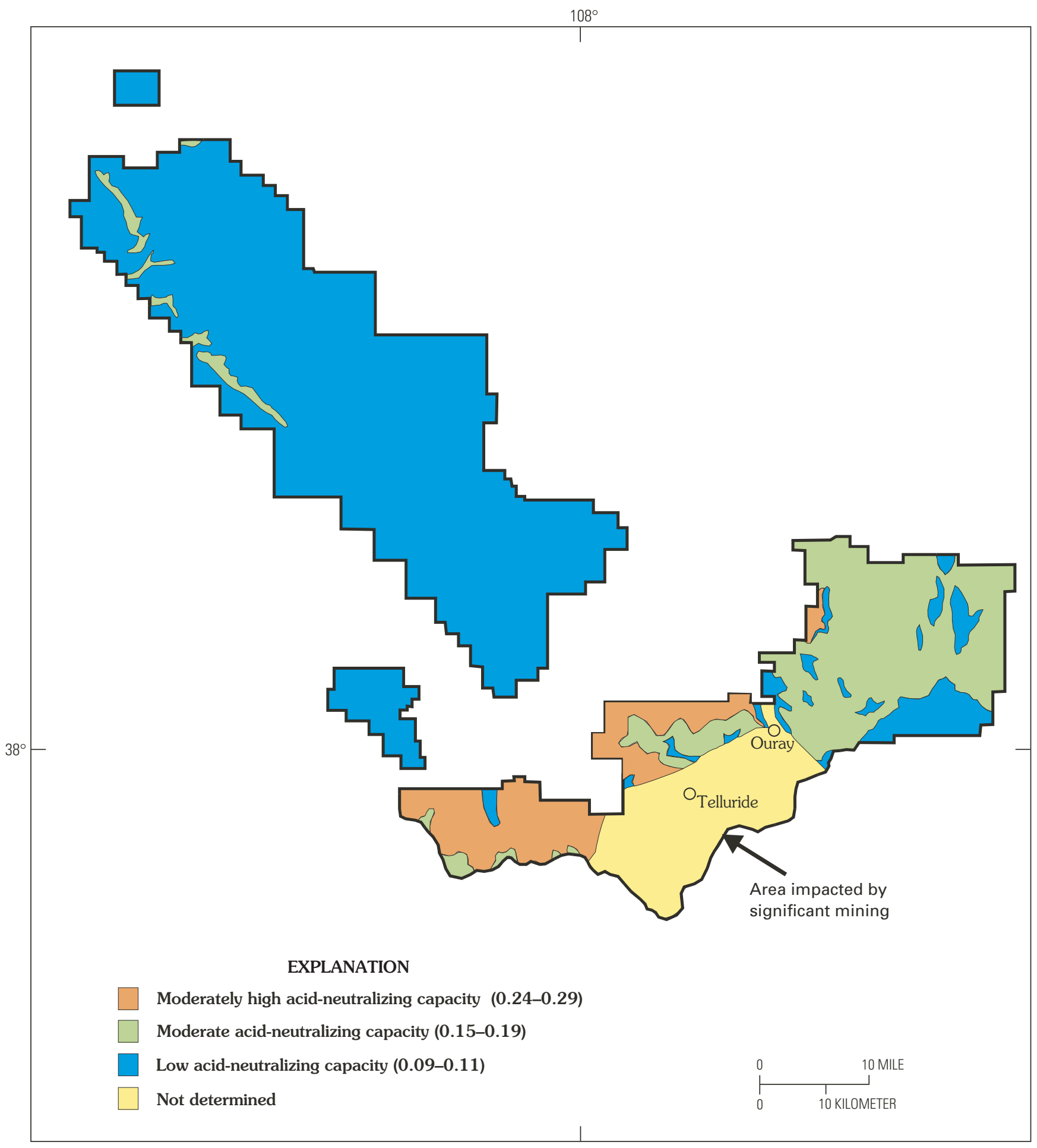

Figure 24. Acid-neutralizing capacity to introduced acidity in the Uncompahgre National Forest, Colorado.

the ten rock composition types in the GMUG area, in order to evaluate effects of mineralization on water chemistry. The chemistry of water from the Redcloud Peak area is similar to, in a qualitative manner only, the natural baselines of water from watersheds in the mined areas in the GMUG areas. This comparison is presented only to show trends of effect of mineralization on water chemistry in watersheds that overlie significantly mineralized rocks; it does not determine the pre-mining natural geochemical baselines of water from mined watersheds in the GMUG area.

The Redcloud Peak area is within the Lake City caldera. Samples of water were collected in July of 1994 from 19 headwater streams in watersheds underlain by the Sunshine Peak silicic alkalic rhyolite tuff. The multiple-flow tuff is more than $1 \mathrm{~km}$ thick. The tuff was densely welded and propylitically altered about 22.5 m.y. ago (Lipman, 1976). The chemical 


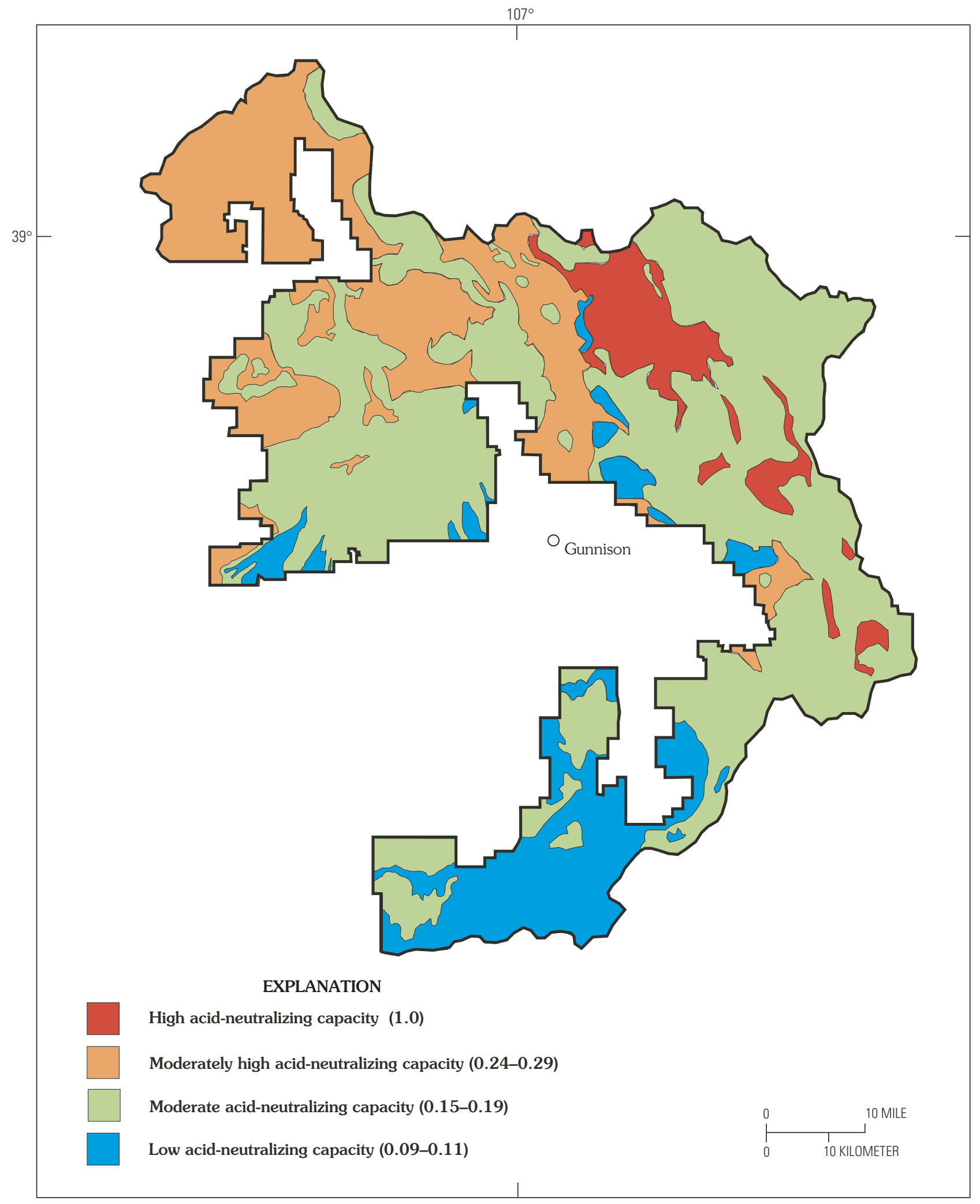

Figure 25. Acid-neutralizing capacity to introduced acidity in the Gunnison National Forest, Colorado.

analyses of the 19 stream water samples are listed in appendix 2. The ranges and means of selected chemical species in stream water samples from the Redcloud Peak area are listed in table 19.
The relief in the Redcloud Peak area is high, and the dominant vegetation is alpine tundra and subalpine forest. The annual precipitation ranges from 25 to $40 \mathrm{in}$. (Colorado Climate Center, 1984). The 19 samples are mostly $\mathrm{Ca}^{2+}-\mathrm{SO}_{4}{ }^{2-}$ type 
Table 17. Chemical speciation of selected elements for water samples from the Grand Mesa, Uncompahgre, and Gunnison National Forests, Colorado.

\begin{tabular}{cc}
\hline Element & Specie \\
$\mathrm{Ca}$ & $\mathrm{Ca}^{2+}$ \\
$\mathrm{Mg}$ & $\mathrm{Mg}^{2+}$ \\
$\mathrm{Na}$ & $\mathrm{Na}^{+}$ \\
$\mathrm{K}$ & $\mathrm{K}^{+}$ \\
$\mathrm{S}$ & $\mathrm{SO}_{4}^{2-}$ \\
$\mathrm{C}$ & $\mathrm{HCO}_{3}^{-}$ \\
$\mathrm{Cl}$ & $\mathrm{Cl}^{-}$ \\
$\mathrm{F}$ & $\mathrm{F}^{-}$ \\
$\mathrm{Si}$ & $\mathrm{H}_{4} \mathrm{SiO}_{4}^{0}$ \\
$\mathrm{Al}$ & $\mathrm{Al}^{-}(\mathrm{OH})_{4}^{-}$ \\
$\mathrm{Fe}$ & $\mathrm{Fe}^{2+}$ \\
$\mathrm{Mn}$ & $\mathrm{Mn}^{2+}, \mathrm{except} \mathrm{Tertiary}^{-}$ \\
& $\mathrm{sediments} \mathrm{as} \mathrm{MnCO}_{3}{ }^{-}$ \\
\hline
\end{tabular}

water, in contrast to the GMUG samples that are mostly $\mathrm{Ca}^{2+}$ $\mathrm{HCO}_{3}{ }^{-}$type water. The samples are acidic to slightly alkaline, and conductivity values are moderately low. Natural acid-drainage waters are present in the upper portions of several of the watersheds. Abundant $\mathrm{Al}$ hydroxides precipitate in and along several streams and at junctions with tributaries. Fe hydroxides also precipitate, but they are not as widespread as the Al hydroxides. The mineralized rocks contain disseminated pyrite, and oxidation and dissolution of the pyrite releases acidity and sulfate to the waters (see Miller and McHugh (1998) for details about natural acid-drainage processes in this area). The $\mathrm{Al}$ is mobilized because of the low $\mathrm{pH}$ values. The values for $\mathrm{pH}$ range from 3.58 to 7.6, with a mean of 6.09 (table 19). The mean $\mathrm{pH}$ value of water from areas underlain by the mineralized Sunshine Peak Tuff is much lower than that in water from areas underlain by the ten predominantly unmineralized rock types from the GMUG (table 20). Because of the low $\mathrm{pH}$, most of the alkalinity generated in the Redcloud Peak area is neutralized and consumed by the acidity released by the weathering of pyrite. The alkalinity values range from 0 to $94 \mathrm{mg} / \mathrm{L}$ as $\mathrm{HCO}_{3}{ }^{-}$, with a mean of $3.9 \mathrm{mg} / \mathrm{L}$. This mean is much lower than the mean alkalinity values of water from the GMUG. If the mean alkalinity values are normalized in a manner similar to the procedure outlined previously for water samples from the GMUG, the mean normalized alkalinity also is much lower than that for water from the GMUG (table 15).

The values for conductivity for water samples from the Redcloud Peak area range from 44 to $320 \mu \mathrm{S} / \mathrm{cm}$, with a mean of $110 \mu \mathrm{S} / \mathrm{cm}$. These moderately low values reflect the large input of runoff from melting snow, the short duration of contact of the water with rocks, and the poor ground-water reservoir in this mountainous headwater area. The concentrations of $\mathrm{Cl}$ are very low, with a mean of $0.12 \mathrm{mg} / \mathrm{L}$, again indication of large runoff from melting snow. The mean TDS value of samples from areas underlain by the Sunshine Peak Tuff is $66.4 \mathrm{mg} / \mathrm{L}$ (table 15). That mean is lower than the means of samples associated with eight of the ten rock composition types from the GMUG. If TDS is normalized in a manner similar to the procedure outlined previously for water from the GMUG, the mean normalized TDS (TDS/Cl) is 552 (table 15). In the GMUG, only the mean normalized TDS value of water from areas underlain by Paleozoic sedimentary rocks is higher than the mean normalized TDS value from the Redcloud Peak area. Therefore the potential release of TDS from areas underlain by the mineralized Sunshine Peak Tuff is higher than that for nine of the ten areas underlain by predominantly unmineralized rocks in the sampled watersheds in the GMUG.

The sulfate concentrations in water samples from areas underlain by the Sunshine Peak Tuff range from 6.9 to $106 \mathrm{mg} /$ $\mathrm{L}$, with a mean of $30 \mathrm{mg} / \mathrm{L}$ (table 19). This mean is much higher than the means of samples from the GMUG watersheds, mainly because larger amounts of pyrite, the likely source of the sulfate, are present in the Sunshine Peak Tuff than in the rocks underlying the watersheds in the GMUG. If the sulfate concentrations are normalized by dividing the sulfate concentrations by $\mathrm{Cl}$ concentrations, to reduce the effect of duration of contact of water and rock and effects of evaporation, the differences are even

Table 18. Saturation indices of selected minerals for water samples from the Grand Mesa, Uncompahgre, and Gunnison National Forests, Colorado.

[Bold type indicates saturation or supersaturation of the water with respect to the mineral phase]

\begin{tabular}{|c|c|c|c|c|c|c|c|c|c|}
\hline Rock composition type & Calcite & Dolomite & Siderite & Rhodochrosite & Chalcedony & Gypsum & Fluorite & Sepiolite & $\mathrm{Al}(\mathrm{OH})_{3}$ \\
\hline Tertiary basalt flows and associated rock & -1.92 & -4.09 & -1.47 & -1.97 & 0.08 & -4.57 & -4.06 & -5.58 & -0.75 \\
\hline Tertiary felsic ash flow tuff & -1.42 & -3.54 & -1.45 & -2.51 & 0.43 & -3.68 & -3.43 & -4.82 & -1.2 \\
\hline Tertiary andesitic lava and breccia & -0.57 & -1.73 & -1.42 & -2.65 & 0.45 & -3.38 & -3.64 & -2.14 & -1.91 \\
\hline Tertiary sedimentary rock & 0.78 & 1.28 & -0.69 & -1.08 & 0.11 & -2.85 & -2.69 & 0.44 & -2.65 \\
\hline Mesozoic sedimentary rock & 0.35 & 0.02 & -1.67 & -2.27 & 0.01 & -2.89 & -2.65 & -2.74 & -2.04 \\
\hline Paleozoic sedimentary rock & 0.51 & 0.45 & -0.89 & -2.18 & -0.24 & -2.47 & -3.17 & -1.92 & -3.72 \\
\hline $\begin{array}{l}\text { Tertiary and Proterozoic intrusive } \\
\text { and Proterozoic metamorphic rocks }\end{array}$ & -1.34 & -3.28 & -1.93 & -3.46 & 0.14 & -3.68 & -2.87 & -4.29 & -1.52 \\
\hline
\end{tabular}


Table 19. Summary of the chemistry of 19 steam water samples from areas underlain by the mineralized Sunshine Peak Tuff, a rhyolitic ash-flow tuff, Redcloud Peak area, Colorado.

\begin{tabular}{|c|c|c|c|}
\hline \multirow[t]{2}{*}{ Measurement ${ }^{1}$} & \multicolumn{2}{|c|}{ Range } & \multirow[t]{2}{*}{ Mean ${ }^{2}$} \\
\hline & Minimum & $\overline{\text { Maximum }}$ & \\
\hline Conductivity & 44 & 320 & 110 \\
\hline TDS & 31.3 & 166.7 & 66.4 \\
\hline $\mathrm{pH}$ & 3.58 & 7.6 & 6.09 \\
\hline $\mathrm{Ca}$ & 6.3 & 33 & 12 \\
\hline $\mathrm{Mg}$ & 0.5 & 4.5 & 1.6 \\
\hline $\mathrm{Na}$ & 0.4 & 4.4 & 1 \\
\hline $\mathrm{K}$ & 0.3 & 4.5 & 1 \\
\hline $\mathrm{SiO}_{2}$ & 32 & 9 & 8.4 \\
\hline Alkalinity & $<1$ & 94 & 3.9 \\
\hline $\mathrm{SO}_{4}$ & 6.9 & 106 & 30 \\
\hline $\mathrm{Cl}$ & $<0.1$ & 0.18 & 0.12 \\
\hline $\mathrm{F}$ & $<0.5$ & 0.96 & 0.17 \\
\hline $\mathrm{Al}$ & $<100$ & 4400 & 420 \\
\hline $\mathrm{Fe}$ & $<10$ & 450 & 30 \\
\hline $\mathrm{Mn}$ & $<10$ & 2000 & 40 \\
\hline $\mathrm{Cu}$ & $<1$ & 6 & 1.2 \\
\hline $\mathrm{Zn}$ & $<5$ & 280 & 11 \\
\hline Mo & $<1$ & 9 & 1 \\
\hline As & $<1$ & 1 & $<1$ \\
\hline $\mathrm{U}$ & $<0.1$ & 8.1 & 0.66 \\
\hline $\mathrm{Li}$ & $<1$ & 21 & 3.7 \\
\hline $\mathrm{Ba}$ & 0.9 & 32 & 7.7 \\
\hline $\mathrm{Sr}$ & 29 & 320 & 72 \\
\hline $\mathrm{Sc}$ & 2 & 8.9 & 5.1 \\
\hline $\mathrm{Rb}$ & 0.8 & 21 & 3.3 \\
\hline $\mathrm{Y}$ & $<0.1$ & 13 & 0.43 \\
\hline $\mathrm{La}$ & $<0.1$ & 66 & 0.58 \\
\hline
\end{tabular}

1TDS, $\mathrm{Ca}, \mathrm{Mg}, \mathrm{Na}, \mathrm{K}, \mathrm{SiO}_{2}, \mathrm{SO}_{4}, \mathrm{Cl}$, and $\mathrm{F}$ in $\mathrm{mg} / \mathrm{L}$; alkalinity in $\mathrm{mg} / \mathrm{L} \mathrm{HCO}_{3}{ }^{-}$; conductivity in $\mu \mathrm{S} / \mathrm{cm}$; remaining elements in $\mu \mathrm{g} / \mathrm{L}$

${ }^{2} \mathrm{All}$ variables are geometric means except for $\mathrm{pH}$, which is arithmetic mean

more striking (table 15). The mean value of $\mathrm{F}$ of water from areas underlain by the Sunshine Peak Tuff is $0.17 \mathrm{mg} / \mathrm{L}$ (table 19). Only water from areas underlain by Tertiary and Proterozoic intrusive and Proterozoic metamorphic rocks in GMUG has a higher mean $\mathrm{F}$ concentration, $0.21 \mathrm{mg} / \mathrm{L}$. If the $\mathrm{F}$ concentration is normalized in a manner similar to the procedure used to normalize sulfate concentrations from GMUG, the mean value of water from areas underlain by the Sunshine Peak Tuff area, 1.41 is higher than any of the mean normalized values from GMUG (table 15). The mean U concentration, $0.66 \mu \mathrm{g} / \mathrm{L}$, in water samples from areas underlain by the Sunshine Peak Tuff, is elevated. The high concentration probably is related to the felsic rock composition. However, it is not as high as the concentration in water in areas underlain by Mesozoic and Tertiary sedimentary rocks and Tertiary and Proterozoic intrusive and
Proterozoic metamorphic rocks (table 20). If $\mathrm{U}$ is normalized in a manner similar to the procedure used for sulfate concentrations from GMUG, the mean normalized value is 5.49. That value is higher than any of the mean normalized values from GMUG (table 15). This indicates that the sulfate, F, and $U$ contents of the Sunshine Peak Tuff are higher than those in rocks in the GMUG study areas.

The mean concentrations of $\mathrm{Cu}, \mathrm{Mo}$, and As are low in samples from areas underlain by the Sunshine Peak Tuff; they are similar to the concentrations in samples from the GMUG watersheds. The mean $\mathrm{Zn}$ concentration, $11 \mu \mathrm{g} / \mathrm{L}$, is high compared to concentrations in samples from GMUG watersheds. The highest mean concentration of $\mathrm{Zn}$ in GMUG, from the Trtiary and Proterozoic intrusive and Proterozoic metamorphic rocks, is $0.64 \mu \mathrm{g} / \mathrm{L}$ (table 20). The mean concentrations of $\mathrm{Al}$ and $\mathrm{Mn}$ are higher in samples from areas underlain by the Sunshine Peak Tuff, with mean concentrations of 420 and $40 \mu \mathrm{g} / \mathrm{L}$, respectively, compared to concentrations in GMUG samples (table 20). Within GMUG, water from areas underlain by Tertiary basaltic rocks contained the highest mean $\mathrm{Al}$ concentration, $54 \mu \mathrm{g} / \mathrm{L}$, nearly an order of magnitude lower than the concentrations in water from areas underlain by the Sunshine Peak Tuff. Weathering of pyrite, present in the Sunshine Peak Tuff, releases acidity and the acidity mobilizes the $\mathrm{Al}$ in the waters. Within GMUG, water from areas underlain by Tertiary sedimentary rocks contained the highest mean Mn concentration, $4.7 \mu \mathrm{g} / \mathrm{L}$, nearly an order of magnitude lower than mean concentrations in water from areas underlain by the Sunshine Peak Tuff (table 20). The mean Fe concentration in samples from areas underlain by the Sunshine Peak Tuff area is $30 \mu \mathrm{g} / \mathrm{L}$, an elevated concentration compared to those from the GMUG watersheds. However, water from areas overlying Tertiary basaltic rocks $(91 \mu \mathrm{g} / \mathrm{L})$ and Tertiary ash-flow tuff $(65 \mu \mathrm{g} / \mathrm{L})$ contained higher mean concentrations of Fe.

\section{Summary and Conclusions}

This study determines, for mountainous headwater areas, the range of baseline geochemistry of stream and spring water in areas that are underlain by each of ten major rock composition types in the Gunnison, Uncompahgre, and Grand Mesa National Forests, Colorado. Chemical processes responsible for the control and mobility of chemical species in water were investigated. By comparing the geochemistry of the water associated with each of the dominant rock composition types, the rock types are characterized with respect to their acid-neutralizing capacities and also to potential release of TDS or chemical weathering. For each of the three national forests, maps were constructed to show potential release of TDS, mean $\mathrm{pH}$ values, and acid-neutralizing capacities, in relation to the distribution of each of the ten major rock composition types. In addition, the geochemistry of water samples from the watersheds in the GMUG, which are underlain by rocks that are relatively unmineralized, is compared to the geochemistry of samples from the Redcloud Peak area, an adjacent area that has been mineralized and probably contains significant mineral deposits. The following are the most significant conclusions of this study: 
Table 20 Comparison of the geochemistry of water samples from watersheds underlain by relatively unmineralized rocks in the Grand Mesa, Uncompahgre, and Gunnison National Forests and water samples from watersheds underlain by the mineralized Sunshine Peak tuff, Redcloud Peak area, Colorado

\begin{tabular}{|c|c|c|c|c|c|c|c|c|c|c|c|c|c|c|c|c|}
\hline Rock composition type & Number & Water Type & $\begin{array}{l}\text { Temp. } \\
{ }^{\circ} \mathrm{C}\end{array}$ & $\mathrm{pH}$ & $\begin{array}{l}\text { Conductivity } \\
\mu \mathrm{S} / \mathrm{cm}\end{array}$ & $\begin{array}{l}\mathrm{TDS} \\
\mathrm{mg} / \mathrm{L}\end{array}$ & $\begin{array}{c}\mathrm{Ca} \\
\mathrm{mg} / \mathrm{L}\end{array}$ & $\begin{array}{l}\mathrm{Mg} \\
\mathrm{mg} / \mathrm{L}\end{array}$ & $\begin{array}{c}\mathrm{Na} \\
\mathrm{mg} / \mathrm{L}\end{array}$ & $\begin{array}{c}\mathrm{K} \\
\mathrm{mg} / \mathrm{L}\end{array}$ & $\begin{array}{l}\mathrm{SiO}_{2} \\
\mathrm{mg} / \mathrm{L}\end{array}$ & $\begin{array}{l}\text { Alkalinity } \\
\mathrm{mg} / \mathrm{L}\end{array}$ & $\begin{array}{l}\mathrm{SO}_{4} \\
\mathrm{mg} / \mathrm{L}\end{array}$ & $\underset{\mathrm{mg} / \mathrm{L}}{\mathrm{Cl}}$ & $\begin{array}{c}\mathrm{F} \\
\mathrm{mg} / \mathrm{L}\end{array}$ & $\begin{array}{c}\mathrm{Al} \\
\mu \mathrm{g} / \mathrm{L}\end{array}$ \\
\hline & \multicolumn{16}{|c|}{ GMUG area } \\
\hline Tertiary basalt flows and associated rock & 4 & $\mathrm{Ca}^{2+}-\mathrm{HCO}_{3}^{-}$ & 12.2 & 7.41 & 63 & 39.3 & 5.4 & 2.1 & 1.8 & 0.37 & 14.3 & 28 & 0.65 & 0.29 & $<0.10$ & 54 \\
\hline Tertiary felsic ash-flow tuff & 5 & $\mathrm{Ca}^{2+}-\mathrm{HCO}_{3}^{-}$ & 9.9 & 7.43 & 100 & 74.5 & 11 & 1.7 & 4.3 & 1.3 & 29.9 & 46 & 2.7 & 0.88 & 0.10 & 16 \\
\hline Tertiary quartz latitic lava and breccia & 4 & $\mathrm{Ca}^{2+}-\mathrm{HCO}_{3}^{-}$ & 7.0 & 7.48 & 124 & 93 & 12.6 & 1.8 & 6.9 & 1.1 & 30.8 & 36 & 16.6 & 0.56 & $<0.10$ & 55 \\
\hline Tertiary andesitic lava and breccia & 9 & $\mathrm{Ca}^{2+}-\mathrm{HCO}_{3}^{-}$ & 12.6 & 7.94 & 151 & 109.4 & 16 & 2.8 & 7.3 & 1.6 & 34.2 & 67 & 4.1 & 0.65 & $<0.10$ & 13 \\
\hline Tertiary sedimentary rocks & 7 & $\mathrm{Ca}^{2+}-\mathrm{HCO}_{3}^{-}$ & 15.9 & 8.50 & 365 & 196 & 39 & 12.0 & 15 & 1.4 & 17.5 & 191 & 8 & 1.4 & 0.16 & 12 \\
\hline Cretaceous Mesaverde Formation & 8 & $\mathrm{Ca}^{2+}-\mathrm{HCO}_{3}^{-}$ & 14.4 & 8.31 & 126 & 69.5 & 13 & 3 & 5.4 & 0.49 & 12.8 & 54 & 5.3 & 0.49 & $<0.10$ & 12 \\
\hline Cretaceous Mancos Shale & 11 & $\mathrm{Ca}^{2+}-\mathrm{HCO}_{3}^{-}$ & 14.4 & 8.24 & 294 & 133.8 & 35 & 8.6 & 6.1 & 0.45 & 13.9 & 104 & 24 & 0.80 & 0.12 & 10 \\
\hline Mesozoic sedimentary rocks & 5 & $\mathrm{Ca}^{2+}-\mathrm{HCO}_{3}^{-}$ & 8.8 & 7.94 & 413 & 200.3 & 59 & 10 & 5.2 & 1.8 & 10.9 & 205 & 4.7 & 3.4 & 0.12 & 6.7 \\
\hline Paleozoic sedimentary rocks & 15 & $\mathrm{Ca}^{2+}-\mathrm{HCO}_{3}^{-}$ & 9.4 & 8.30 & 356 & 174 & 52.6 & 11.0 & 1.3 & 0.47 & 6.3 & 143 & 13.5 & $<0.25$ & $<0.1$ & 0.34 \\
\hline $\begin{array}{l}\text { Tertiary and Proterozoic intrusive and } \\
\text { Proterozoic metamorphic rocks }\end{array}$ & 8 & $\mathrm{Ca}^{2+}-\mathrm{HCO}_{3}^{-}$ & 7.3 & 7.82 & 83 & 50.9 & 8 & 1.7 & 3.1 & 0.55 & 14.3 & 34 & 3.5 & 0.39 & 0.21 & 14 \\
\hline
\end{tabular}

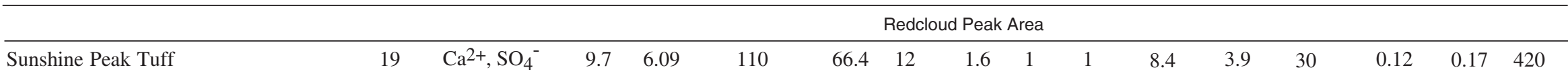

\begin{tabular}{|c|c|c|c|c|c|c|c|c|c|c|c|c|c|c|c|c|c|}
\hline Rock composition type & $\begin{array}{c}\mathrm{Fe} \\
\mu \mathrm{g} / \mathrm{L}\end{array}$ & $\begin{array}{l}\mathrm{Mn} \\
\mu \mathrm{g} / \mathrm{L}\end{array}$ & $\begin{array}{c}\mathrm{Cu} \\
\mu \mathrm{g} / \mathrm{L}\end{array}$ & $\begin{array}{l}\mathrm{Zn} \\
\mu \mathrm{g} / \mathrm{L}\end{array}$ & $\begin{array}{c}\mathrm{Co} \\
\mu \mathrm{g} / \mathrm{L}\end{array}$ & $\begin{array}{l}\text { Mo } \\
\mu \mathrm{g} / \mathrm{L}\end{array}$ & $\begin{array}{c}\mathrm{Ni} \\
\mu \mathrm{g} / \mathrm{L}\end{array}$ & $\begin{array}{c}\mathrm{Cr} \\
\mu \mathrm{g} / \mathrm{L}\end{array}$ & $\begin{array}{l}\text { As } \\
\mu \mathrm{g} / \mathrm{L}\end{array}$ & $\begin{array}{c}U \\
\mu \mathrm{g} / \mathrm{L}\end{array}$ & $\begin{array}{c}\mathrm{Li} \\
\mu \mathrm{g} / \mathrm{L}\end{array}$ & $\begin{array}{c}\mathrm{Be} \\
\mu \mathrm{g} / \mathrm{L}\end{array}$ & $\begin{array}{c}\mathrm{Ba} \\
\mu \mathrm{g} / \mathrm{L}\end{array}$ & $\begin{array}{c}\mathrm{Sc} \\
\mu \mathrm{g} / \mathrm{L}\end{array}$ & $\begin{array}{c}\mathrm{Rb} \\
\mu \mathrm{g} / \mathrm{L}\end{array}$ & $\begin{array}{c}Y \\
\mu \mathrm{g} / \mathrm{L}\end{array}$ & $\begin{array}{l}\mathrm{La} \\
\mu \mathrm{g} / \mathrm{L}\end{array}$ \\
\hline & \multicolumn{17}{|c|}{ GMUG area } \\
\hline Tertiary basalt flows and associated rock & 91 & 15 & $<1$ & 0.40 & $<0.5$ & $<0.5$ & $<2$ & $<0.1$ & 0.05 & 0.07 & $<0.5$ & $<0.05$ & 14 & 21 & 0.50 & 0.41 & 0.25 \\
\hline Tertiary felsic ash-flow tuff & 65 & 2.9 & $<1$ & 0.24 & $<0.5$ & $<0.5$ & $<2$ & $<0.1$ & 1.2 & 0.06 & 1.5 & $<0.05$ & 18 & 34 & 1.2 & 0.10 & 0.024 \\
\hline Tertiary quartz latitic lava and breccia & 60 & 2.7 & 0.56 & 0.5 & 0.06 & 0.41 & 0.4 & $<1$ & $<3$ & 0.14 & 3.6 & $<0.05$ & 4.6 & 2.9 & 1.4 & 0.32 & 0.13 \\
\hline Tertiary andesitic lava and breccia & 15 & 0.5 & $<1$ & 0.21 & $<0.5$ & $<0.5$ & $<2$ & $<0.1$ & 0.47 & 0.08 & 1.2 & $<0.05$ & 4.6 & 39 & 2.3 & 0.07 & $<0.005$ \\
\hline Tertiary sedimentary rocks & 13 & 4.7 & $<1$ & 0.22 & $<0.5$ & 1.9 & $<2$ & $<0.1$ & 1.9 & 1.4 & 7.2 & $<0.05$ & 62 & 25 & 0.60 & 0.083 & 0.017 \\
\hline Cretaceous Mesaverde Formation & 14 & 2.0 & $<1$ & 0.24 & $<0.5$ & $<0.5$ & $<2$ & $<0.1$ & 0.08 & 0.14 & 1.4 & $<0.05$ & 18 & 18 & 0.32 & 0.04 & 0.005 \\
\hline Cretaceous Mancos Shale & 17 & 3.0 & $<1$ & 0.22 & $<0.5$ & 0.77 & $<2$ & $<0.1$ & 0.16 & 0.35 & 2.0 & $<0.05$ & 19 & 20 & 0.20 & 0.06 & $<0.005$ \\
\hline Mesozoic sedimentary rocks & 4.6 & 0.68 & $<1$ & 0.23 & $<0.5$ & $<0.5$ & $<2$ & $<0.1$ & 1.2 & 2.7 & 12 & $<0.05$ & 286 & 15 & 2.4 & 0.03 & 0.006 \\
\hline Paleozoic sedimentary rocks & $<20$ & 0.57 & $<0.5$ & 0.6 & 0.06 & 0.41 & 1.2 & 2.6 & $<3$ & 0.56 & 2.1 & $<0.05$ & 88.5 & 0.9 & 0.47 & 0.03 & $<0.01$ \\
\hline $\begin{array}{l}\text { Tertiary and Proterozoic intrusive and } \\
\text { Proterozoic metamorphic rocks }\end{array}$ & 13 & $<0.3$ & $<1$ & 0.64 & $<0.5$ & 0.83 & $<2$ & $<0.1$ & $<0.03$ & 0.78 & 1.7 & $<0.05$ & 8.6 & 19 & 0.35 & 0.17 & 0.036 \\
\hline
\end{tabular}

Redcloud Peak Area

\begin{tabular}{llllllllllllllllll}
\hline Sunshine Peak Tuff & 30 & 40 & 1.2 & 11 & 1.1 & 1 & 1.1 & $<0.2$ & $<1$ & 0.66 & 3.7 & 0.48 & 7.7 & 5.1 & 3.3 & 0.43 & 0.58
\end{tabular}


1. The baseline geochemistry of stream and spring water in the mountainous headwater areas is controlled primarily by the chemical composition of the underlying bedrock. Each rock composition type produces a unique range of water compositions. Other factors, such as annual precipitation, temperature, topographic setting, the physical character of minerals, such as grain size and crystallinity, and biotic activity are important, but they mainly influence the rates of chemical reactions but not which elements are present in the water.

2. The water in the headwater areas in GMUG generally is $\mathrm{Ca}^{2+}$ $\mathrm{HCO}_{3}{ }^{-}$type water, with alkaline $\mathrm{pH}$ values and low to moderate total dissolved solids. The water generally is of good chemical quality, with low concentrations of elements such as $\mathrm{Cu}, \mathrm{Zn}, \mathrm{Mo}, \mathrm{As}, \mathrm{U}, \mathrm{Al}, \mathrm{Fe}$, and Mn. Slightly elevated concentrations of some of these elements in some areas are caused by the presence and dissolution of pyrite and other minerals. The dominant chemical species in most of the water samples are $\mathrm{Ca}^{2+}, \mathrm{Mg}^{2+}, \mathrm{Na}^{+}, \mathrm{K}^{+}, \mathrm{SO}_{4}{ }^{2-}$, $\mathrm{HCO}_{3}{ }^{-}, \mathrm{Cl}^{-}, \mathrm{F}^{-}, \mathrm{H}_{4} \mathrm{SiO}_{4}{ }^{0}, \mathrm{Al}(\mathrm{OH})_{4}{ }^{-}, \mathrm{Fe}^{2+}$, and $\mathrm{Mn}^{2+}$.

3. The chloride concentrations in most of the samples from the three national forests are generally low, indicating that there is a significant snow and storm runoff component in stream water. Shallow soil zones and minimal ground-water reservoirs characterize the mountainous headwater areas. Therefore, except for water in areas underlain by Mesozoic and Tertiary sedimentary rocks, the duration of contact of water with the rocks is short and evaporation processes are minimal.

4. The TDS values, which are measures of chemical weathering rates, are highest for watersheds underlain by Mesozoic and Tertiary sedimentary rocks. The lowest TDS values are from samples from watersheds that are underlain by Tertiary basalt and by Tertiary and Proterozoic intrusive and Proterozoic metamorphic rocks, which consist of granodiorite, quartz monzonite, granite, diorite, gneiss, and gabbro. If TDS values are normalized by dividing the TDS value by $\mathrm{Cl}$ concentration to reduce the effects of duration of contact of water and rock and the effects of evaporation processes, the highest potential release of TDS is from Paleozoic sedimentary rocks, followed by the Mancos Shale, Tertiary sedimentary rocks, and the Mesaverde Formation. The calculated potential release of TDS does not take into account the amount of precipitation in an area.

5. Sulfate concentrations in water samples from areas underlain by Paleozoic sedimentary rocks are as high as several hundred $\mathrm{mg} / \mathrm{L}$. The high concentration probably is due to dissolution of gypsum in the Minturn and Belden Formations and the lower part of the Maroon Formation.

6. Alkalinity is a measure of the acid-neutralizing capacity of waters to introduced acidification. Water from Mesozoic and Tertiary sedimentary rocks has the highest mean alkalinity values. The water that has the lowest mean alkalinity values and that is most susceptible to introduced acidity is from the top of Grand Mesa. Grand Mesa is composed of basaltic rocks. When alkalinity values are normalized by dividing TDS value by $\mathrm{Cl}$ to reduce the effects of evaporation and the duration of contact of water and rocks, the water samples with the highest mean normalized alkalinity are from watersheds underlain by Paleozoic sedimentary rocks, followed by the Mancos Shale and Tertiary sedimentary rocks. The higher normalized alkalinity values of water from watersheds underlain by these rocks probably are caused by carbonate rocks and local calcareous zones present within the bedrock units. The waters in watersheds underlain by these sedimentary rocks have the greatest acid-neutralizing capacity and are most resistant to introduced acidification from processes such as acid-mine drainage or dry fallout from coal-burning power plants. The water with the lowest mean normalized alkalinity values is from watersheds that are underlain by Tertiary ash-flow tuff and Tertiary and Proterozoic intrusive and Proterozoic metamorphic rocks; these watersheds are the most susceptible to introduced acidification.

7. The Tertiary sedimentary rocks contain oil shale. The shale outcrops in some of the sampled watersheds. These rocks contain pyrite, generally with elevated trace metal concentrations. Sulfate concentration as high as $25 \mathrm{mg} / \mathrm{L}$, in samples from these watersheds, probably indicates weathering of pyrite. However, enough calcareous material is present to generate sufficient alkalinity to neutralize the acidity. The higher $\mathrm{pH}$ values ensure that trace metals that are present as cations form hydroxides or are adsorbed, and thus their concentrations are low. The concentration of arsenic, present as an anion, is slightly elevated (as high as $5.8 \mu \mathrm{g} / \mathrm{L}$ ). Overall, there is only a slight impact of the oil shale on the chemical quality of water in these mountainous headwater areas.

8. The Mesaverde Formation contains extensive coal deposits that contain pyrite. The sulfate concentration in water samples from watersheds in areas underlain by Mesaverde Formation (as high as $19 \mathrm{mg} / \mathrm{L}$ ) probably reflects weathering of pyrite. However, the $\mathrm{pH}$ values are alkaline, indicating that generated acidity is buffered by the alkalinity. The mean alkalinity value is moderately low, at $54 \mathrm{mg} / \mathrm{L}$ as $\mathrm{HCO}_{3}{ }^{-}$, probably because the acidity generated from weathering pyrite neutralizes and lowers the alkalinity. In addition, the lower alkalinity may also be due to less calcareous material in the Mesaverde Formation. Overall, the chemical quality of the water from areas underlain by the Mesaverde Formation is good, but water in areas underlain by Mesaverde Formation is more susceptible to introduced acidification than is water associated with the other sedimentary rock units in GMUG.

9. The Mancos Shale is marine in origin. It contains black shale and associated pyrite and it has elevated trace metal concentrations. Calcareous-rich zones locally are present, and high alkalinity is produced in water from areas underlain by these rocks. The high alkalinity buffers acidity produced by the oxidizing pyrite and, because of the higher $\mathrm{pH}$ values, it reduces the mobility of trace metal cations. Se from the Mancos Shale is in elevated concentrations in water in the lower parts of the valleys downstream from the headwater areas. Se concentrations in water are low (mean Se $<0.2 \mu \mathrm{g} / \mathrm{L}$ ) in the sampled mountainous headwater watersheds that are underlain by Mancos Shale. The high 
Se concentrations in topographically lower, more arid areas underlain by the Mancos Formation outside the GMUG area probably are concentrated by evaporation effects. The water from these mountainous headwater areas is well buffered, and overall chemical quality is good.

10. The Mesozoic sedimentary rocks contain uranium concentrations that were mined adjacent to the GMUG area, along the west flank of the Uncompahgre plateau. Water from these rocks in GMUG contains only slightly elevated concentrations of uranium (as high as $5.8 \mu \mathrm{g} / \mathrm{L}$ ) and the uranium is not a problem to water quality.

11. Parts of the GMUG area are heavily grazed by cattle. The cattle tend to concentrate in wetlands, where their hoofs muddy and disturb the surface. This physical disturbance, along with the cattle waste, decreases the oxygen content of the water leading to more reducing conditions. One impact on water quality appears to be increased mobility of Fe due to the more reducing conditions. Overall, the chemical quality of the water is not significantly impacted.

The unique geochemical baselines for water samples from areas underlain by the ten rock composition types demonstrate the importance of the composition of the bedrock in determining the geochemistry of water in these mountainous headwater areas. The geochemical baselines provide values that approximate the natural background geochemistry of the stream and spring water in these watersheds for each of the ten major rock composition types. Comparison of these geochemical baselines with future baselines will allow recognition of any significant changes in water quality.

\section{References Cited}

Apodaca, L.E., Driver, N.E., Stephens, V.C., and Spahr, N.E., 1996, Envi ronmental setting and implications on water quality, upper Colorado River Basin, Colorado and Utah: U.S. Geological Survey WaterResources Investigations Report 95-4263, 33 p.

Barnes, Ivan, and Clark, F.E., 1969, Chemical properties of ground water and their corrosion and encrustation effects on wells: U.S. Geologi cal Survey Professional Paper 498-D, $58 \mathrm{p}$.

Benci, J.F, and McKee, T.B., 1977, Colorado monthly temperature and precipitation summary for the period 1951-1970: Fort Collins, Colorado State University, Climatology Report 77-1, 300 p.

Benedict, A.D., 1991, The southern Rockies: San Francisco, Sierra Club Books, $578 \mathrm{p}$.

Bradley, W.H., 1964, Geology of the Green River Formation and associated Eocene rocks in southwestern Wyoming and adjacent parts of Colorado and Utah: U. S. Geological Survey Professional Paper 496-A, $86 \mathrm{p}$.

Carroll, Dorothy, 1962, Rainwater as a chemical agent of geologic pro cesses-A review: U.S. Geological Survey Water-Supply Paper $1535-\mathrm{G}, 18 \mathrm{p}$.

Colorado Climate Center, 1984, Colorado average annual precipitation 1951-1980: Fort Collins, Colorado State University, Department Atmospheric Science, Climate Center, scale1:500,000.

Edwards, T.K., and Glysson, G.D., 1988, Field methods for measurement of fluvial sediment: U.S. Geological Survey Open-File Report 86-531, $118 \mathrm{p}$.
Fishman, M.J. and Pyen, G., 1979, Determination of selected anions in water by ion chromatography: U.S. Geological Survey WaterResources Investigations 79-101, $30 \mathrm{p}$.

Forstner, Ulrich, and Wittmann, G.T.W., 1979, Metal pollution in the aquatic environment: New York, Springer Verlag, $486 \mathrm{p}$.

Gaskill, D.L., Mutschler, F.E., and Bartleson, B.L., 1981, West Elk volcanic field, Gunnison and Delta Counties, Colorado, in Epis, R.C., and Callender, J.F., eds., Western slope, Colorado; western Colorado and eastern Utah: New Mexico Geological Society Guidebook no 32, p. 305-316.

Hansen W.R., 1965, The Black Canyon of the Gunnison, today and yester day: U.S. Geological Survey Bulletin 1191, 76 p.

Harrison, W.J., Pevear, D.R., and Lindahl, P.C., 1992, Trace elements in pyrites of the Green River Formation oil shale, Wyoming, Utah, and Colorado, in Tuttle, M.L, ed., Geochemical, biogeochemical, and sedimentological studies of the Green River Formation, Wyoming, Utah, and Colorado: U.S. Geological Survey Bulletin 1973, p. D1D18.

Hem, J.D., 1992, Study and interpretation of the chemical characteristics of natural water: U.S. Geological Survey Water-Supply Paper 2254, $263 \mathrm{p}$.

Hunt, C.B., 1974, Natural regions of the United States and Canada: San Francisco, W.H. Freeman and Company, $725 \mathrm{p}$.

Lipman, P.W., 1976, Geologic map of the Lake City caldera area, western San Juan Mountains, southwestern Colorado: U.S. Geological Survey Miscellaneous Investigations Series Map I-962, scale $1: 48,000$.

Livingstone, D.A., 1963, Chemical composition of rivers and lakes (6th ed.): U.S. Geological Survey Professional Paper 440-G, p. G5-G64.

Miller, W.R., and McHugh, J.B., 1998, Geochemical baselines and pro cesses affecting surface water, Redcloud Peak area, Colorado: U.S. Geological Survey Open-File Report 98-35, 20 p.

Orion Research, Incorporated, 1978, Analytical methods guide (9th ed.): Cambridge, Massachusetts, $48 \mathrm{p}$.

Parkhurst, D.L., 1995, User's guide to PHREEQC—A computer program for speciation, reaction-path, advective-transport, and inverse geochemical calculations: U.S. Geological Survey Water-Resourc es Investigations Report 95-4227, 143 p.

Roehler, H.W., 1974, Depositional environments of rocks in the Piceance Creek basin, Colorado, in Murray, D.K., ed., Energy resources of the Piceance Creek basin, Colorado: Rocky Mountain Association of Geologists Guidebook, Twenty-fifth field conference, p. 57-69.

Tuttle, M.L., 1992, Geochemical, biogeochemical, and sedimentological studies of the Green River Formation, Wyoming, Utah, and Colorado: U.S. Geological Survey Bulletin 1973, p. A1-A5.

Tweto, Ogden, 1976, Preliminary geologic map of the Montrose $1^{\circ} \times 2^{\circ}$ quadrangle, southwestern Colorado: U.S. Geological Survey Mis cellaneous Field Studies Map MF-761, scale 1:250,000.

1979, Geologic map of Colorado: U.S. Geological Survey, scale $1: 1,500,000$.

U.S. Department of Agriculture, 1972, Natural vegetation, Colorado: scale 1:1,500,000.

Wright, W.G., and Butler, D.L., 1993, Distribution and mobilization of dis solved selenium in ground water of the irrigated Grand and Uncompahgre Valleys, western Colorado, in Allen, R.G., and Neale, C.M.U., eds., Management of irrigated and drainage system, inte grated perspectives: American Society of Civil Engineers, New York, p. $770-777$. 
Appendix 1. Chemical analyses of stream and spring water samples from watersheds underlain by the ten dominant rock composition types in the Grand Mesa, Uncompahgre, and Gunnison National Forests, Colorado.

[Leader indicates (_) not determined]

\begin{tabular}{|c|c|c|c|c|c|c|c|}
\hline \multirow[t]{2}{*}{ Sample no. } & \multicolumn{3}{|c|}{ Latitude } & & ongitud & & Dominant rock type \\
\hline & Degree & Minute & Second & Degree & Minute & Second & \\
\hline & & & & & Tertiary & alt (table & \\
\hline G14 & 39 & 1 & 58 & 108 & 10 & 34 & Basaltic flows, tuff, breccia, conglomerate \\
\hline G15 & 39 & 0 & 34 & 108 & 11 & 29 & Basaltic flows, tuff, breccia, conglomerate \\
\hline G16 & 39 & 0 & 3 & 108 & 10 & 36 & Basaltic flows, tuff, breccia, conglomerate \\
\hline G17 & 38 & 0 & 7 & 108 & 9 & 41 & Basaltic flows, tuff, breccia, conglomerate \\
\hline & & & & & Tertiary & h flow tuf & \\
\hline G45 & 38 & 12 & 6 & 106 & 50 & 53 & Ash flow tuff, felsic \\
\hline G46 & 38 & 10 & 20 & 106 & 51 & 15 & Ash flow tuff, felsic \\
\hline G56 & 38 & 8 & 29 & 106 & 48 & 23 & Ash flow tuff, felsic \\
\hline G57 & 38 & 4 & 56 & 106 & 50 & 2 & Ash flow tuff, felsic \\
\hline G58 & 38 & 6 & 12 & 106 & 49 & 30 & Ash flow tuff, felsic \\
\hline & & & & & Tertiar & Iartz latite & \\
\hline $\mathrm{C} 12$ & 38 & 03 & 1 & 107 & 21 & 3 & Quartz latitic lavas and breccias \\
\hline $\mathrm{C} 13$ & 38 & 03 & 8 & 107 & 22 & 3 & Quartz latitic lavas and breccias \\
\hline $\mathrm{C} 14$ & 38 & 11 & 5 & 107 & 21 & 8 & Quartz latitic lavas and breccias \\
\hline $\mathrm{C} 15$ & 38 & 12 & 0 & 107 & 22 & 3 & Quartz latitic lavas and breccias \\
\hline & & & & & Terti & andesite & \\
\hline G47 & 38 & 38 & 49 & $106 ?$ & 19 & 17 & Andesitic lava, breccia, tuff, conglomerate \\
\hline G48 & 38 & 36 & 23 & 107 & 19 & 58 & Andesitic lava, breccia, tuff, conglomerate \\
\hline G49 & 38 & 35 & 11 & 107 & 20 & 14 & Andesitic lava, breccia, tuff, conglomerate \\
\hline G50 & 38 & 34 & 39 & 107 & 19 & 59 & Andesitic lava, breccia, tuff, conglomerate \\
\hline G51 & 38 & 34 & 25 & 107 & 20 & 1 & Andesitic lava, breccia, tuff, conglomerate \\
\hline G52 & 38 & 33 & 35 & 107 & 19 & 43 & Andesitic lava, breccia, tuff, conglomerate \\
\hline G54 & 38 & 32 & 45 & 107 & 19 & 19 & Andesitic lava, breccia, tuff, conglomerate \\
\hline G55 & 38 & 30 & 42 & 107 & 18 & 53 & Andesitic lava, breccia, tuff, conglomerate \\
\hline & & & & & ertiary s & nentary $\mathrm{r}$ & \\
\hline G01 & 39 & 17 & 1 & 107 & 34 & 50 & Claystone, carbonate. shale, lignite \\
\hline G02 & 39 & 14 & 46 & 107 & 41 & 1 & Claystone, carbonate. shale, lignite \\
\hline G03 & 39 & 20 & 26 & 107 & 50 & 33 & Shale, sandstone, marlstone, oil shale \\
\hline G04 & 39 & 20 & 19 & 107 & 50 & 6 & Shale, sandstone, marlstone, oil shale \\
\hline G05 & 39 & 19 & 12 & 107 & 57 & 10 & Shale, oil shale, siltstone, sandstone, marl \\
\hline G06 & 39 & 91 & 7 & 107 & 55 & 5 & Oil shale, siltstone, sandstone, marl \\
\hline G07 & 39 & 12 & 18 & 107 & 48 & 46 & Shale, sandstone, marlstone, oil shale \\
\hline & & & & & ceous $\mathrm{N}$ & verde For & ation \\
\hline G32 & 38 & 48 & 45 & 107 & 18 & 45 & Sandstone, shale, coal \\
\hline G33 & 38 & 48 & 49 & 107 & 18 & 44 & Sandstone, shale, coal \\
\hline G34 & 38 & 48 & 43 & 108 & 18 & 20 & Sandstone, shale, coal \\
\hline G35 & 38 & 50 & 37 & 107 & 19 & 7 & Sandstone, shale, coal \\
\hline G36 & 38 & 50 & 36 & 107 & 19 & 8 & Sandstone, shale, coal \\
\hline G37 & 38 & 52 & 38 & 107 & 20 & 4 & Sandstone, shale, coal \\
\hline G38 & 38 & 55 & 17 & 107 & 20 & 7 & Sandstone, shale, coal \\
\hline G39 & 38 & 55 & 44 & 107 & 20 & 18 & Sandstone, shale, coal \\
\hline & & & & & retaceo & lancos Sh & \\
\hline G19 & 38 & 48 & 17 & 107 & 33 & 29 & Marine shale \\
\hline $\mathrm{G} 20$ & 38 & 48 & 8 & 107 & 33 & 56 & Marine shale \\
\hline $\mathrm{G} 24$ & 37 & 55 & 41 & 108 & 12 & 20 & Marine shale \\
\hline $\mathrm{G} 25$ & 37 & 53 & 31 & 108 & 12 & 0 & Marine shale \\
\hline G26 & 37 & 53 & 17 & 108 & 11 & 52 & Marine shale \\
\hline $\mathrm{G} 27$ & 37 & 54 & 8 & 108 & 14 & 0 & Marine shale \\
\hline $\mathrm{G} 28$ & 37 & 54 & 32 & 108 & 10 & 45 & Marine shale \\
\hline G29 & 37 & 54 & 10 & 108 & 10 & 30 & Marine shale \\
\hline G30 & 37 & 54 & 3 & 108 & 93 & 1 & Marine shale \\
\hline G31 & 37 & 53 & 29 & 108 & 70 & 0 & Marine shale \\
\hline & & & & & esozoic & imentary & \\
\hline G09 & 38 & 44 & 41 & 108 & 32 & 59 & Sandstone, siltstone, shale, limestone, conglomerate \\
\hline G10 & 38 & 44 & 48 & 108 & 33 & 23 & Sandstone, siltstone, shale, limestone, conglomerate \\
\hline G11 & 38 & 40 & 59 & 108 & 41 & 25 & Sandstone, sandy shale, mudstone, limestone \\
\hline G12 & 38 & 38 & 8 & 108 & 41 & 22 & Sandstone, mudstone, limestone \\
\hline G13 & 38 & 35 & 25 & 108 & 38 & 56 & Sandstone, mudstone, limestone \\
\hline & & & & & leozoic & imentary & \\
\hline $\mathrm{C} 01$ & 38 & 49 & 31 & 106 & 50 & 54 & Carbonate, quartzite \\
\hline $\mathrm{C} 02$ & 38 & 50 & 44 & 106 & 49 & 13 & Sandstone, grit, conglomerate, shale, limestone \\
\hline $\mathrm{C} 03$ & 38 & 51 & 32 & 106 & 48 & 19 & Sandstone, conglomerate, mudstone, shale, grit, limestone, shale \\
\hline $\mathrm{C} 04$ & 38 & 52 & 17 & 106 & 47 & 52 & Sandstone, conglomerate, mudstone \\
\hline $\mathrm{C} 05$ & 38 & 53 & 5 & 106 & 47 & 25 & Sandstone, conglomerate, mudstone \\
\hline $\mathrm{C} 06$ & 38 & 53 & 38 & 106 & 46 & 55 & Sandstone, conglomerate, mudstone \\
\hline $\mathrm{C} 07$ & 38 & 57 & 55 & 106 & 46 & 11 & Sandstone, grit, conglomerate, shale, carbonate \\
\hline $\mathrm{C} 08$ & 38 & 57 & 37 & 106 & 46 & 13 & Sandstone, grit, conglomerate, shale, carbonate \\
\hline $\mathrm{C} 09$ & 38 & 56 & 58 & 106 & 46 & 18 & Sandstone, grit, conglomerate, shale, carbonate \\
\hline $\mathrm{C} 10$ & 38 & 55 & 50 & 106 & 46 & 10 & Sandstone, conglomerate, mudstone \\
\hline $\mathrm{C} 11$ & 38 & 54 & 37 & 106 & 46 & 56 & Sandstone, conglomerate, mudstone \\
\hline $\mathrm{C} 16$ & 38 & 51 & 23 & 106 & 42 & 42 & Sandstone, grit, conglomerate, shale, carbonate, mudstone \\
\hline $\mathrm{C} 17$ & 38 & 49 & 54 & 106 & 43 & 10 & Sandstone, grit, conglomerate, shale, carbonate, mudstone \\
\hline $\mathrm{C} 18$ & 38 & 49 & 32 & 106 & 43 & 42 & Sandstone, grit, conglomerate, shale, carbonate, mudstone \\
\hline $\mathrm{C} 19$ & 38 & 49 & 10 & 106 & 44 & 17 & Carbonate, sandstone, quartzite, grit, conglomerate, shale \\
\hline & & & & & tiary an & oterozoic & \\
\hline G21 & 38 & 26 & 31 & 106 & 21 & 47 & Granite, quartz monzonite, granodiorite \\
\hline $\mathrm{G} 22$ & 38 & 31 & 46 & 106 & 24 & 19 & Granite, intermediate to felsic intrusive rock \\
\hline $\mathrm{G} 23$ & 38 & 31 & 57 & 106 & 24 & 9 & Granite, intermediate to felsic intrusive rock \\
\hline G40 & 38 & 34 & 10 & 106 & 33 & 35 & Felsic and hornblende gneiss \\
\hline G41 & 38 & 34 & 46 & 106 & 32 & 32 & Granite, quartz monzonite, granodiorite \\
\hline G42 & 38 & 35 & 6 & 106 & 32 & 18 & Granite, quartz monzonite, granodiorite \\
\hline G43 & 38 & 37 & 36 & 106 & 25 & 19 & Felsic intrusive rock \\
\hline G44 & 38 & 37 & 42 & 106 & 24 & 22 & Felsic intrusive rock \\
\hline
\end{tabular}


Appendix 1- Continued. Chemical analyses of stream and spring water samples from watersheds underlain by the ten dominant rock composition types in the Grand Mesa, Uncompahgre, and Gunnison National Forests, Colorado.

[Leader indicates (_) not determined]

\begin{tabular}{|c|c|c|c|c|c|c|}
\hline Sample no. & Water type & $\begin{array}{c}\text { Estimated flow, } \\
\text { gallons per minute }\end{array}$ & Comments & $\begin{array}{l}\text { Temperature } \\
\text { in }{ }^{\circ} \mathrm{C} \\
\end{array}$ & $\mathrm{pH}$ & $\begin{array}{l}\text { Conductivity } \\
\text { in } \mu \mathrm{S} / \mathrm{cm}\end{array}$ \\
\hline \multicolumn{7}{|c|}{ Tertiary basalt } \\
\hline G14 & unnamed stream & 0.004 & nearly dry & 13.6 & 7.09 & 59 \\
\hline G15 & Coal Creek & 0.5 & cattle signs & 13.1 & 7.37 & 66 \\
\hline G16 & unnamed stream & $15-20$ & yellow color, from wetlands & 9.5 & 7.67 & 66 \\
\hline G17 & unnamed stream & $2-4$ & from wetlands & 12.7 & 7.49 & 62 \\
\hline \multicolumn{7}{|c|}{ Tertiary ash flow tuff } \\
\hline G45 & spring & $0.125-0.25$ & clear & 8.7 & 7.40 & 139 \\
\hline G46 & Blue Creek & $1-2$ & hard to filter, wetlands, some sediments & 13.1 & 8.02 & 132 \\
\hline G56 & spring & $0.062-0.125$ & water from steel pipe, clear & 6 & 6.89 & 117 \\
\hline G57 & Perfecto Creek & $7-15$ & yellow color, hard to filter, old cattle signs & 10.6 & 7.37 & 57 \\
\hline G58 & Pauline Creek & $40-50$ & yellow color, hard to filter & 10.9 & 7.46 & 81 \\
\hline \multicolumn{7}{|c|}{ Tertiary quartz latite } \\
\hline $\mathrm{C} 12$ & Mineral Creek & 100 & some sediments in water, hard to filter & 7.4 & 7.4 & 136 \\
\hline $\mathrm{C} 13$ & small stream & 0.25 & sediments, hard to filter, rain & 7 & 7.35 & 108 \\
\hline $\mathrm{C} 14$ & small stream & 4 & silt, hard to filter, rain & 5.7 & 7.4 & 140 \\
\hline C15 & small stream & 4 & silty from raising stream, rain & 7.7 & 7.75 & 116 \\
\hline & & & Tertiary andesite & & & \\
\hline G47 & West Soap Creek & $15-30$ & clear & 12.4 & 7.49 & 104 \\
\hline G48 & Lion Gulch & 0.125 & clear & 12.3 & 8.20 & 242 \\
\hline G49 & unnamed stream & 0.125 & intermittent flow in bed & 16.2 & 8.53 & 185 \\
\hline G50 & unnamed stream & 1 & clear & 11.8 & 7.93 & 160 \\
\hline G51 & unnamed stream & $0.125-0.25$ & clear, hard to filter & 10.9 & 7.97 & 144 \\
\hline G52 & unnamed stream & 0.25 & clear & 12.4 & 8.06 & 170 \\
\hline G54 & Oregon Gulch & $5-10$ & clear & 11.4 & 7.90 & 142 \\
\hline G55 & Chance Gulch & 1 & hard to filter, orange color & 13.5 & 7.86 & 150 \\
\hline & & & Tertiary sedimentary rock & & & \\
\hline G01 & Hightower Creek & $0.25-0.5$ & hard to filter, cattle signs & 21.6 & 8.46 & 467 \\
\hline G02 & unnamed stream & $0.25-0.5$ & some sediments, cattle signs & 23.5 & 8.69 & 652 \\
\hline G03 & West Bush Creek & 15 & some sediments, cattle signs & 16 & 8.51 & 247 \\
\hline G04 & East Bush Creek & $22-30$ & clear & 14.8 & 8.65 & 365 \\
\hline G05 & Kimball Creek & $0.5-1$ & clear & 9.1 & 8.47 & 523 \\
\hline G06 & unnamed stream & 15 & clear & 12.9 & 8.16 & 195 \\
\hline G07 & Park Creek & $22-30$ & hard to filter & 13.4 & 8.55 & 310 \\
\hline & & & Cretaceous Mesaverde Formation & & & \\
\hline G32 & Coal Creek & $40-75$ & murky, some sediments & 11.1 & 8.36 & 117 \\
\hline G33 & Robenson Creek & $7.5-15$ & murky, some sediments & 15.7 & 8.57 & 268 \\
\hline G34 & spring & 0.125 & clear & 11.3 & 8.00 & 257 \\
\hline G35 & Cliff Creek & 75 & clear & 11.9 & 8.10 & 76 \\
\hline G36 & Coal Creek & $75-112$ & some sediments, hard to filter & 13.3 & 8.30 & 124 \\
\hline G37 & Coal Creek & 187 & slightly murky & 14 & 8.36 & 98 \\
\hline G38 & Coal Creek & $187-225$ & clear & 17.7 & 8.26 & 103 \\
\hline G39 & & $60-75$ & clear & 20 & 8.54 & 85 \\
\hline & & & Cretaceous Mancos Shale & & & \\
\hline G19 & spring & 0.25 & series of springs, cattle signs & 11.4 & 7.46 & 219 \\
\hline G20 & springs & $0.5-0.75$ & series of springs, cattle signs & 9.7 & 8.17 & 401 \\
\hline G24 & unnamed stream & 15 & hard to filter, some sediments & 13.5 & 8.14 & 345 \\
\hline $\mathrm{G} 25$ & West Beaver Creek & $7.5-15$ & clear & 13.4 & 8.26 & 294 \\
\hline G26 & East Beaver Creek & $15-22$ & clear & 7.6 & 8.26 & 107 \\
\hline G27 & unnamed stream & $1-2$ & clear & 8.6 & 8.16 & 286 \\
\hline $\mathrm{G} 28$ & unnamed stream & $0.5-1$ & drainage from wetlands, cattle signs & 20.2 & 8.22 & 245 \\
\hline G29 & Beaver Creek & 1 & cattle impacted, meadows & 22 & 8.48 & 272 \\
\hline G30 & Spring Creek & $0.5-1$ & clear & 16.1 & 8.58 & 338 \\
\hline G31 & McCullach Creek & 2 & clear & 11.8 & 8.29 & 210 \\
\hline & & & Mesozoic sedimentary rock & & & \\
\hline G09 & Big Dominguez Creek & 22 & clear & 13.7 & 8.53 & 299 \\
\hline G10 & spring & $.062-0.125$ & galvanized pipe coated with carbonate & 11.4 & 8.25 & 454 \\
\hline G11 & spring & $1-2$ & clear & 7.2 & 7.74 & 527 \\
\hline G12 & spring & 0.25 & clear & 6.6 & 7.48 & 460 \\
\hline G13 & California Spring & 0.25 & water from plastic pipe & 4.9 & 7.71 & 363 \\
\hline & & & Paleozoic sedimentary rock & & & \\
\hline $\mathrm{C} 01$ & Walrod Gulch & 5 & some silt & 8.6 & 8.33 & 442 \\
\hline $\mathrm{C} 02$ & small stream & 2 & abundant cream colored coatings & 12.4 & 8.23 & 429 \\
\hline $\mathrm{C} 03$ & small stream & 4 & some silt & 8.8 & 8.36 & 331 \\
\hline $\mathrm{C} 04$ & small stream & 10 & clear & 7.6 & 8.13 & 225 \\
\hline $\mathrm{C} 05$ & small stream & 7 & clear & 7.2 & 8.25 & 252 \\
\hline $\mathrm{C} 06$ & small stream & 7 & clear & 8.1 & 8.4 & 272 \\
\hline $\mathrm{C} 07$ & Upper Cement Creek & 1 & small mine above & 11.2 & 8.14 & 424 \\
\hline $\mathrm{C} 08$ & small stream & 0.75 & coming from wetland & 11.5 & 8.17 & 403 \\
\hline $\mathrm{C} 09$ & small stream & 10 & clear & 9.4 & 8.44 & 659 \\
\hline $\mathrm{C} 10$ & small stream & 5 & clear & 7.3 & 8.38 & 491 \\
\hline $\mathrm{C} 11$ & small stream & 8 & clear & 9 & 8.39 & 300 \\
\hline C16 & small stream & 10 & clear & 5.7 & 8.2 & 263 \\
\hline $\mathrm{C} 17$ & spring & 1 & coming from wetland & 10.7 & 7.97 & 452 \\
\hline $\mathrm{C} 18$ & small stream & 2 & clear & 11.5 & 8.47 & 327 \\
\hline C19 & Deadman Gulch & 25 & clear & 11.5 & 8.59 & 298 \\
\hline & & & Tertiary and Proterozoic rock & & & \\
\hline G21 & spring & $2-4$ & water from steel pipe & 7.7 & 6.89 & 74 \\
\hline G22 & unnamed stream & 2 & clear & 11.2 & 7.63 & 71 \\
\hline G23 & Spring Creek & 1 & clear & 9 & 7.79 & 126 \\
\hline G40 & unnamed stream & 0.25 & clear & 12.1 & 8.14 & 97 \\
\hline G41 & unnamed stream & 0.125 & clear & 10.3 & 8.18 & 118 \\
\hline G42 & unnamed stream & 0.25 & clear & 10.8 & 8.18 & 123 \\
\hline G43 & Fitzpatrick Gulch & $7.5-15$ & clear & 6.5 & 8.00 & 47 \\
\hline G44 & Tunnel Gulch & 7.5 & clear & 7.3 & 7.75 & 53 \\
\hline
\end{tabular}


Appendix 1- Continued. Chemical analyses of stream and spring water samples from watersheds underlain by the ten dominant rock composition types in the Grand Mesa, Uncompahgre, and Gunnison National Forests, Colorado.

\begin{tabular}{|c|c|c|c|c|c|c|c|c|c|c|c|c|}
\hline Sample no. & $\begin{array}{l}\mathrm{TDS} \\
\mathrm{mg} / \mathrm{L}\end{array}$ & $\begin{array}{c}\mathrm{Ca} \\
\mathrm{mg} / \mathrm{L}\end{array}$ & $\begin{array}{c}\mathrm{Mg} \\
\mathrm{mg} / \mathrm{L}\end{array}$ & $\begin{array}{c}\mathrm{Na} \\
\mathrm{mg} / \mathrm{L}\end{array}$ & $\begin{array}{c}\mathrm{K} \\
\mathrm{mg} / \mathrm{L}\end{array}$ & $\begin{array}{l}\mathrm{SiO}_{2} \\
\mathrm{mg} / \mathrm{L}\end{array}$ & $\begin{array}{l}\text { Alkalinity } \\
\mathrm{mg}^{-} \mathrm{L} \mathrm{HCO}_{3}\end{array}$ & $\begin{array}{c}\mathrm{SO}_{4} \\
\mathrm{mg} / \mathrm{L}\end{array}$ & $\begin{array}{c}\mathrm{Cl} \\
\mathrm{mg} / \mathrm{L}\end{array}$ & $\begin{array}{c}\mathrm{F} \\
\mathrm{mg} / \mathrm{L}\end{array}$ & $\begin{array}{c}\mathrm{N} \text { (nitrate) } \\
\mathrm{mg} / \mathrm{L}\end{array}$ & $\begin{array}{c}\mathrm{Al} \\
\mu \mathrm{g} / \mathrm{L}\end{array}$ \\
\hline & & & & & & Tertia & asalt & & & & & \\
\hline G14 & 32 & 4.05 & 1.77 & 1.5 & 0.2 & 10.9 & 24 & 1.60 & 0.31 & $<0.10$ & $<0.125$ & 107 \\
\hline G15 & 40 & 5.89 & 2.24 & 1.92 & 0.4 & 13.7 & 30 & 0.378 & 0.60 & $<0.10$ & $<0.125$ & 54 \\
\hline G16 & 46 & 6.10 & 2.29 & 2.02 & 0.5 & 19.0 & 30 & 0.638 & $<0.25$ & $<0.10$ & $<0.125$ & 38 \\
\hline G17 & 41 & 5.65 & 2.13 & 1.92 & 0.4 & 14.9 & 30 & 0.453 & $<0.25$ & $<0.10$ & $<0.125$ & 40 \\
\hline & & & & & & ertiary a & low tuff & & & & & \\
\hline G45 & 106 & 16.5 & 2.80 & 5.12 & 1 & 39.6 & 70 & 3.85 & 1.9 & 0.14 & 0.172 & 8 \\
\hline G46 & 99 & 13.3 & 1.71 & 7.86 & 2 & 41.2 & 52 & 5.96 & 1.3 & 0.13 & $<0.125$ & 32 \\
\hline G56 & 84 & 14.4 & 2.03 & 3.7 & 1 & 32.6 & 54 & 2.13 & 1.1 & 0.11 & $<0.125$ & 7 \\
\hline G57 & 49 & 5.30 & 0.826 & 3.47 & 1 & 20.8 & 32 & 1.37 & 0.55 & $<0.10$ & $<0.125$ & 34 \\
\hline G58 & 53 & 8.44 & 1.63 & 3.1 & 0.9 & 19.2 & 34 & 2.07 & 0.37 & $<0.10$ & $<0.125$ & 17 \\
\hline & & & & & & ertiary & tz latite & & & & & \\
\hline $\mathrm{C} 12$ & 75 & 15.7 & 2.58 & 3.67 & 1.17 & 9.49 & 29 & 27.9 & $<0.25$ & $<0.1$ & $<0.1$ & 7.90 \\
\hline $\mathrm{C} 13$ & 80 & 8.74 & 0.78 & 13 & 2.19 & 26.1 & 35 & 10.4 & 1.50 & $<0.1$ & $<0.1$ & 356 \\
\hline $\mathrm{C} 14$ & 78 & 14.5 & 2.94 & 7.94 & 0.688 & 12.3 & 44 & 17.1 & 0.56 & $<0.1$ & $<0.1$ & 58.9 \\
\hline $\mathrm{C} 15$ & 69 & 12.7 & 1.92 & 6.14 & 0.878 & 14.2 & 36 & 15.2 & 0.58 & $<0.1$ & $<0.1$ & 55.4 \\
\hline & & & & & & Tertiary & desite & & & & & \\
\hline G47 & 101 & 19.3 & 3.32 & 7.28 & 2 & 39.4 & 32 & 14.0 & 0.34 & $<0.10$ & $<0.125$ & 12 \\
\hline G48 & 133 & 9.95 & 1.74 & 14.8 & 1 & 31.6 & 102 & 22.5 & 0.82 & $<0.10$ & $<0.125$ & 9 \\
\hline G49 & 88 & 11.4 & 1.66 & 4.91 & 0.8 & 21.9 & 84 & 5.16 & 0.70 & 0.11 & $<0.125$ & 10 \\
\hline G50 & 121 & 22.2 & 7.72 & 12.4 & 2 & 34.7 & 80 & 1.88 & 0.70 & $<0.10$ & $<0.125$ & 16 \\
\hline G51 & 100 & 21.5 & 4.20 & 5.68 & 2 & 29.5 & 68 & 2.74 & 0.76 & 0.14 & 0.136 & 12 \\
\hline G52 & 109 & 14.8 & 2.84 & 11.1 & 2 & 35.0 & 82 & 2.58 & 0.71 & $<0.10$ & $<0.125$ & 21 \\
\hline G54 & 113 & 16.5 & 3.03 & 5.55 & 2 & 47.4 & 72 & 1.36 & 0.81 & 0.10 & $<0.125$ & 14 \\
\hline G55 & 117 & 18.9 & 2.33 & 5.54 & 2 & 48.1 & 78 & 0.757 & 0.99 & $<0.10$ & $<0.125$ & 14 \\
\hline & & & & & & iary sed & ntary rock & & & & & \\
\hline G01 & 250 & 62.3 & 11.4 & 20.5 & 4 & 6.5 & 250 & 14.0 & 8.3 & 0.51 & $<0.125$ & 24 \\
\hline G02 & 330 & 42.7 & 36.9 & 45.1 & 3 & 19.6 & 352 & 5.34 & 3.4 & 0.17 & $<0.125$ & 11 \\
\hline G03 & 152 & 31.4 & 6.61 & 9.31 & 0.7 & 17.2 & 160 & 7.39 & 0.63 & 0.11 & $<0.125$ & 16 \\
\hline G04 & 191 & 44.5 & 11.5 & 14.1 & 0.6 & 19.8 & 182 & 10.3 & 0.69 & 0.14 & $<0.125$ & 21 \\
\hline G05 & 274 & 56.1 & 12.6 & 32.2 & 0.8 & 26.8 & 242 & 25.4 & 1.3 & 0.21 & $<0.125$ & $<3$ \\
\hline G06 & 108 & 18.2 & 7.84 & 5.21 & 2 & 26.1 & 92 & 3.36 & 0.75 & 0.07 & $<0.125$ & 14 \\
\hline G07 & 157 & 37.0 & 10.2 & 7.25 & 1 & 16.9 & 160 & 4.82 & 0.72 & 0.15 & $<0.125$ & 16 \\
\hline & & & & & Cret & ous Mes & rde Formation & & & & & \\
\hline G32 & 65 & 12.9 & 2.86 & 4.43 & 0.5 & 13.8 & 44 & 8.71 & 0.33 & $<0.10$ & $<0.125$ & 10 \\
\hline G33 & 139 & 30.5 & 7.85 & 8.41 & 0.8 & 10.7 & 122 & 19.2 & 1.0 & 0.16 & $<0.125$ & 13 \\
\hline G34 & 123 & 23.8 & 8.29 & 13.4 & 0.3 & 13.1 & 112 & 7.81 & 0.99 & 0.11 & $<0.125$ & 15 \\
\hline G35 & 47 & 7.67 & 1.31 & 4.25 & 0.4 & 14.5 & 34 & 1.48 & 0.25 & $<0.10$ & $<0.125$ & 9 \\
\hline G36 & 68 & 13.5 & 3.06 & 4.22 & 0.5 & 11.9 & 52 & 8.46 & 0.40 & $<0.10$ & $<0.125$ & 12 \\
\hline G37 & 55 & 10.6 & 2.16 & 4.39 & 0.4 & 12.8 & 40 & 4.65 & 0.37 & $<0.10$ & $<0.125$ & 10 \\
\hline G38 & 57 & 10.8 & 2.22 & 4.88 & 0.4 & 12.7 & 42 & 4.81 & 0.49 & $<0.10$ & $<0.125$ & 9 \\
\hline G39 & 50 & 8.83 & 1.67 & 3.8 & 0.6 & 12.6 & 40 & 1.67 & 0.57 & $<0.10$ & $<0.125$ & 27 \\
\hline & & & & & & aceous & cos Shale & & & & & \\
\hline G19 & 124 & 27.4 & 6.42 & 6.61 & 0.2 & 21.6 & 88 & 17.5 & 0.97 & 0.10 & $<0.125$ & 8 \\
\hline G20 & 212 & 50.3 & 13.3 & 12.8 & 0.2 & 27.1 & 162 & 27.2 & 1.9 & 0.14 & $<0.125$ & 16 \\
\hline G24 & 175 & 48.2 & 10.6 & 3.99 & 0.7 & 12.0 & 168 & 16.1 & 0.59 & 0.15 & $<0.125$ & 8 \\
\hline G25 & 147 & 41.9 & 7.64 & 3.46 & 0.5 & 8.6 & 120 & 25.9 & 0.40 & 0.16 & $<0.125$ & 11 \\
\hline G26 & 56 & 12.0 & 2.26 & 2.71 & 0.2 & 9.5 & 30 & 13.9 & 0.26 & $<0.10$ & $<0.125$ & 15 \\
\hline G27 & 140 & 32.3 & 11.1 & 3.01 & 0.2 & 12.1 & 106 & 29.0 & 0.45 & $<0.10$ & $<0.125$ & 4 \\
\hline G28 & 129 & 32.4 & 5.23 & 4.87 & 1 & 9.5 & 84 & 34.7 & 0.38 & 0.19 & $<0.125$ & 10 \\
\hline G29 & 143 & 33.6 & 8.32 & 6.97 & 0.5 & 15.7 & 144 & 6.06 & 1.0 & 0.13 & $<0.125$ & 13 \\
\hline G30 & 176 & 47.0 & 10.6 & 5.91 & 0.5 & 16.2 & 180 & 6.16 & 1.0 & 0.14 & $<0.125$ & 10 \\
\hline G31 & 107 & 22.0 & 7.18 & 2.53 & 0.4 & 9.5 & 58 & 36.5 & 0.31 & $<0.10$ & $<0.125$ & 12 \\
\hline & & & & & & ozoic se & entary rock & & & & & \\
\hline G09 & 143 & 43.5 & 7.43 & 3.38 & 2 & 6.9 & 152 & 2.50 & 2.5 & 0.12 & $<0.125$ & 7 \\
\hline G10 & 222 & 60.6 & 13.5 & 10.3 & 2 & 16.9 & 214 & 7.94 & 6.1 & 0.13 & $<0.125$ & 12 \\
\hline G11 & 248 & 83.8 & 10.8 & 3.51 & 1 & 9.1 & 262 & 5.16 & 5.8 & 0.15 & 0.316 & 4 \\
\hline G12 & 222 & 73.1 & 11.3 & 2.02 & 2 & 7.8 & 246 & 3.17 & 1.6 & 0.15 & 0.153 & $<3$ \\
\hline G13 & 185 & 43.6 & 9.14 & 14.9 & 3 & 19.0 & 172 & 7.05 & 3.5 & $<0.10$ & 0.445 & 18 \\
\hline & & & & & & zzoic se & entary rock & & & & & \\
\hline $\mathrm{C} 01$ & 213 & 55.3 & 20.4 & 5.38 & 1.33 & 6.29 & 180 & 33.5 & 1.69 & 0.2 & 0.2 & 1.96 \\
\hline $\mathrm{C} 02$ & 213 & 51.2 & 25 & 1.21 & 0.79 & 6.89 & 194 & 32.4 & 0.44 & $<0.1$ & 0.2 & $<0.1$ \\
\hline $\mathrm{C} 03$ & 149 & 44.2 & 14.2 & 1.66 & 0.574 & 7.02 & 148 & 8.0 & $<0.25$ & $<0.1$ & $<0.1$ & 0.39 \\
\hline $\mathrm{C} 04$ & 105 & 40.6 & 2.94 & 0.945 & 0.201 & 4.88 & 110 & 0.8 & $<0.25$ & $<0.1$ & $<0.1$ & 4.32 \\
\hline $\mathrm{C} 05$ & 118 & 44.1 & 3.29 & 1.59 & 0.288 & 7.23 & 120 & 1.6 & $<0.25$ & $<0.1$ & $<0.1$ & $<0.1$ \\
\hline C06 & 130 & 47.2 & 4.17 & 1.73 & 0.496 & 7.27 & 138 & 1.1 & $<0.25$ & $<0.1$ & $<0.1$ & $<0.1$ \\
\hline $\mathrm{C} 07$ & 225 & 63.4 & 16.3 & 0.609 & 0.231 & 4.71 & 178 & 52.0 & $<0.25$ & $<0.1$ & $<0.1$ & 0.75 \\
\hline C08 & 201 & 57.4 & 17 & 0.61 & 0.108 & 4.41 & 165 & 40.4 & $<0.25$ & $<0.1$ & $<0.1$ & $<0.1$ \\
\hline $\mathrm{C} 09$ & 387 & 101 & 19.5 & 0.742 & 0.598 & 3.72 & 118 & 203.6 & $<0.25$ & $<0.1$ & $<0.1$ & 0.71 \\
\hline $\mathrm{C} 10$ & 260 & 63.7 & 20.1 & 0.773 & 0.723 & 4.86 & 138 & 102.2 & $<0.25$ & $<0.1$ & $<0.1$ & $<0.1$ \\
\hline $\mathrm{C} 11$ & 138 & 44.5 & 10.6 & 1.18 & 0.451 & 5.99 & 139 & 6.1 & $<0.25$ & $<0.1$ & $<0.1$ & 0.98 \\
\hline $\mathrm{C} 16$ & 120 & 44.3 & 4.83 & 1.49 & 0.603 & 9.60 & 112 & 3.8 & $<0.25$ & 0.1 & $<0.1$ & $<0.1$ \\
\hline $\mathrm{C} 17$ & 224 & 64.3 & 17.6 & 2.07 & 0.626 & 8.62 & 169 & 47.4 & $<0.25$ & 0.1 & $<0.1$ & 7.67 \\
\hline C18 & 160 & 47 & 12.9 & 1.68 & 1.13 & 11.64 & 138 & 17.2 & $<0.25$ & $<0.1$ & $<0.1$ & $<0.1$ \\
\hline C19 & 137 & 44.4 & 11.3 & 0.977 & 0.371 & 5.88 & 135 & 7.8 & $<0.25$ & $<0.1$ & $<0.1$ & 0.77 \\
\hline & & & & & & ry and & rozoic rock & & & & & \\
\hline G21 & 54 & 5.89 & 1.24 & 5.01 & 0.6 & 22.3 & 28 & 4.09 & 0.90 & $<0.10$ & $<0.125$ & 47 \\
\hline G22 & 47 & 6.41 & 1.13 & 3.23 & 0.8 & 15.9 & 20 & 9.83 & 0.27 & $<0.10$ & $<0.125$ & 18 \\
\hline $\mathrm{G} 23$ & 77 & 11.8 & 4.09 & 3.59 & 0.6 & 21.3 & 42 & 14.7 & 0.36 & $<0.10$ & $<0.125$ & 9 \\
\hline G40 & 58 & 9.38 & 2.86 & 3.03 & 0.7 & 13.2 & 50 & 3.58 & 0.49 & 0.69 & $<0.125$ & 13 \\
\hline G41 & 67 & 10.3 & 3.93 & 5.27 & 0.6 & 19.4 & 50 & 2.38 & 0.55 & 1.8 & $<0.125$ & 25 \\
\hline G42 & 63 & 9.70 & 4.03 & 5.05 & 0.6 & 16.9 & 48 & 2.70 & 0.54 & 2.2 & $<0.125$ & 17 \\
\hline G43 & 31 & 5.81 & 0.555 & 1.58 & 0.4 & 9.0 & 26 & 1.03 & $<0.25$ & $<0.10$ & $<0.125$ & 5 \\
\hline G44 & 30 & 7.05 & 0.507 & 1.15 & 0.2 & 6.1 & 26 & 1.56 & $<0.25$ & $<0.10$ & $<0.125$ & 9 \\
\hline
\end{tabular}


Appendix 1- Continued. Chemical analyses of stream and spring water samples from watersheds underlain by the ten dominant rock composition types in the Grand Mesa, Uncompahgre, and Gunnison National Forests, Colorado.

[Leader indicates (_) not determined]

\begin{tabular}{|c|c|c|c|c|c|c|c|c|c|c|c|c|c|}
\hline Sample no. & $\begin{array}{c}\mathrm{Fe} \\
\mu \mathrm{g} / \mathrm{L}\end{array}$ & $\begin{array}{c}\mathrm{Mn} \\
\mu \mathrm{g} / \mathrm{L} \\
\end{array}$ & $\begin{array}{c}\mathrm{Ba} \\
\mu \mathrm{g} / \mathrm{L}\end{array}$ & $\begin{array}{c}\mathrm{Be} \\
\mu \mathrm{g} / \mathrm{L}\end{array}$ & $\begin{array}{c}\mathrm{Cd} \\
\mu \mathrm{g} / \mathrm{L}\end{array}$ & $\begin{array}{c}\text { Co } \\
\mu \mathrm{g} / \mathrm{L}\end{array}$ & $\begin{array}{c}\mathrm{Cu} \\
\mu \mathrm{g} / \mathrm{L}\end{array}$ & $\begin{array}{c}\mathrm{Li} \\
\mu \mathrm{g} / \mathrm{L} \\
\end{array}$ & $\begin{array}{c}\mathrm{Ni} \\
\mu \mathrm{g} / \mathrm{L}\end{array}$ & $\begin{array}{c}\mathrm{Sr} \\
\mu \mathrm{g} / \mathrm{L}\end{array}$ & $\begin{array}{c}\mathrm{Ti} \\
\mu \mathrm{g} / \mathrm{L} \\
\end{array}$ & $\begin{array}{c}\mathrm{Zn} \\
\mu \mathrm{g} / \mathrm{L}\end{array}$ & $\begin{array}{c}\mathrm{V} \\
\mu \mathrm{g} / \mathrm{L} \\
\end{array}$ \\
\hline & & & & & & Tertiar & & & & & & & \\
\hline G14 & 44 & 4 & 17 & $<0.05$ & $<0.5$ & $<0.5$ & $<1$ & $<0.5$ & $<2$ & 29 & 4 & 0.4 & $<0.5$ \\
\hline G15 & 125 & 27 & 14 & $<0.05$ & $<0.5$ & $<0.5$ & $<1$ & $<0.5$ & $<2$ & 39 & 2 & 0.5 & $<0.5$ \\
\hline G16 & 151 & 21 & 10 & $<0.05$ & $<0.5$ & $<0.5$ & $<1$ & $<0.5$ & $<2$ & 38 & $<2$ & 0.4 & 0.57 \\
\hline G17 & 81 & 19 & 15 & $<0.05$ & $<0.5$ & $<0.5$ & $<1$ & $<0.5$ & $<2$ & 37 & $<2$ & 0.3 & $<0.5$ \\
\hline & & & & & & rtiary a & $v$ tuff & & & & & & \\
\hline G45 & 12 & 22 & 5 & $<0.05$ & $<0.5$ & $<0.5$ & $<1$ & 2 & $<2$ & 107 & $<2$ & 0.3 & $<0.5$ \\
\hline G46 & 61 & 22 & 19 & $<0.05$ & $<0.5$ & $<0.5$ & $<1$ & 3 & $<2$ & 109 & $<2$ & 0.2 & 3.38 \\
\hline G56 & 9 & $<0.3$ & 32 & $<0.05$ & $<0.5$ & $<0.5$ & $<1$ & 2 & $<2$ & 79 & $<2$ & $<.2$ & 2.31 \\
\hline G57 & 255 & 11 & 0 & $<0.05$ & $<0.5$ & $<0.5$ & $<1$ & 0.9 & $<2$ & 47 & $<2$ & 0.3 & 0.79 \\
\hline G58 & 640 & 32 & 12 & 0.06 & $<0.5$ & $<0.5$ & $<1$ & 0.9 & $<2$ & 72 & $<2$ & 0.3 & 1.26 \\
\hline & & & & & & rtiary $\mathrm{a}$ & atite & & & & & & \\
\hline $\mathrm{C} 12$ & 0.0724 & 21.4 & 13.2 & $<0.05$ & $<0.5$ & 0.07 & 0.76 & 1.7 & 0.4 & 171 & 0.5 & 0.6 & 0.8 \\
\hline $\mathrm{C} 13$ & 0.159 & 2.2 & 3.54 & 0.1 & $<0.5$ & 0.09 & 0.74 & 10.0 & 0.4 & 57.6 & 7.6 & 1 & 1.6 \\
\hline C14 & 0.0331 & 1.0 & 2.59 & $<0.05$ & $<0.5$ & 0.04 & $<0.5$ & 3.0 & 0.3 & 163 & 1.9 & 0.5 & 1.0 \\
\hline $\mathrm{C} 15$ & 0.0338 & 1.1 & 3.81 & $<0.05$ & $<0.5$ & 0.05 & 0.60 & 3.4 & 0.4 & 109 & 1.4 & $<0.5$ & 1.2 \\
\hline & & & & & & Tertiary & & & & & & & \\
\hline G47 & 14 & $<0.3$ & 6 & $<0.05$ & $<0.5$ & $<0.5$ & $<1$ & 1 & $<2$ & 112 & $<2$ & $<.2$ & 0.80 \\
\hline G48 & 16 & 3 & 1 & $<0.05$ & $<0.5$ & $<0.5$ & $<1$ & 1 & $<2$ & 60 & $<2$ & $<.2$ & 2.07 \\
\hline G49 & 9 & 0.6 & 3 & $<0.05$ & $<0.5$ & $<0.5$ & $<1$ & 0.8 & $<2$ & 62 & $<2$ & 0.2 & 2.63 \\
\hline G50 & 11 & $<0.3$ & 5 & $<0.05$ & $<0.5$ & $<0.5$ & $<1$ & 3 & $<2$ & 97 & $<2$ & 0.3 & 2.32 \\
\hline G51 & 14 & 0.3 & 9 & $<0.05$ & $<0.5$ & $<0.5$ & $<1$ & 1 & $<2$ & 149 & $<2$ & 0.4 & 2.92 \\
\hline G52 & 16 & $<0.3$ & 6 & $<0.05$ & $<0.5$ & $<0.5$ & $<1$ & 0.9 & $<2$ & 121 & $<2$ & 0.3 & 2.69 \\
\hline G54 & 24 & $<0.3$ & 8 & $<0.05$ & $<0.5$ & $<0.5$ & $<1$ & 1 & $<2$ & 100 & $<2$ & $<.2$ & 2.67 \\
\hline G55 & 31 & 4 & 8 & $<0.05$ & $<0.5$ & $<0.5$ & $<1$ & 2 & $<2$ & 92 & $<2$ & 0.2 & 2.67 \\
\hline & & & & & & ary sed & ry rock & & & & & & \\
\hline G01 & 36 & 171 & 208 & $<0.05$ & $<0.5$ & $<0.5$ & 2 & 3 & $<2$ & 348 & $<2$ & 0.5 & 1.56 \\
\hline G02 & 17 & 6 & 118 & $<0.05$ & $<0.5$ & $<0.5$ & 1 & 25 & $<2$ & 718 & $<2$ & 0.3 & 4.18 \\
\hline G03 & 9 & 9 & 42 & $<0.05$ & $<0.5$ & $<0.5$ & $<1$ & 5 & $<2$ & 202 & $<2$ & $<.2$ & 3.13 \\
\hline G04 & 7 & 2 & 36 & $<0.05$ & $<0.5$ & $<0.5$ & $<1$ & 9 & $<2$ & 326 & $<2$ & $<.2$ & 4.40 \\
\hline G05 & $<5$ & $<0.3$ & 44 & $<0.05$ & $<0.5$ & $<0.5$ & $<1$ & 17 & $<2$ & 452 & $<2$ & $<.2$ & 5.51 \\
\hline G06 & 16 & 23 & 2 & $<0.05$ & $<0.5$ & $<0.5$ & $<1$ & 1 & $<2$ & 114 & $<2$ & 0.2 & 2.10 \\
\hline G07 & 26 & 76 & 9 & $<0.05$ & $<0.5$ & $<0.5$ & $<1$ & 12 & $<2$ & 337 & $<2$ & 0.3 & 1.28 \\
\hline & & & & & & us Mes & Forma & & & & & & \\
\hline G32 & 13 & 21 & 1 & $<0.05$ & $<0.5$ & $<0.5$ & $<1$ & 1 & $<2$ & 82 & $<2$ & 0.3 & $<0.5$ \\
\hline G33 & 18 & 74 & 9 & $<0.05$ & $<0.5$ & $<0.5$ & $<1$ & 5 & $<2$ & 226 & $<2$ & 0.3 & $<0.5$ \\
\hline G34 & $<5$ & 23 & 5 & $<0.05$ & $<0.5$ & $<0.5$ & $<1$ & 2 & $<2$ & 364 & $<2$ & $<.2$ & $<0.5$ \\
\hline G35 & 25 & 11 & 1 & $<0.05$ & $<0.5$ & $<0.5$ & $<1$ & 0.7 & $<2$ & 52 & $<2$ & 0.2 & 0.71 \\
\hline G36 & 14 & 21 & 4 & $<0.05$ & $<0.5$ & $<0.5$ & $<1$ & 2 & $<2$ & 89 & $<2$ & 0.2 & $<0.5$ \\
\hline G37 & 13 & 11 & 2 & $<0.05$ & $<0.5$ & $<0.5$ & $<1$ & 1 & $<2$ & 70 & $<2$ & 0.3 & $<0.5$ \\
\hline G38 & 12 & 21 & 4 & $<0.05$ & $<0.5$ & $<0.5$ & $<1$ & 1 & $<2$ & 74 & $<2$ & 0.2 & $<0.5$ \\
\hline G39 & 30 & 22 & 9 & $<0.05$ & $<0.5$ & $<0.5$ & $<1$ & 0.8 & $<2$ & 75 & $<2$ & 0.4 & 0.74 \\
\hline & & & & & & ceous & s Shale & & & & & & \\
\hline G19 & 15 & 51 & 4 & $<0.05$ & $<0.5$ & $<0.5$ & $<1$ & 2 & $<2$ & 241 & $<2$ & 0.5 & 0.74 \\
\hline G20 & 15 & 13 & 5 & $<0.05$ & $<0.5$ & $<0.5$ & $<1$ & 2 & $<2$ & 581 & $<2$ & 0.2 & 0.73 \\
\hline G24 & 39 & 29 & 35 & $<0.05$ & $<0.5$ & $<0.5$ & $<1$ & 2 & $<2$ & 192 & $<2$ & 0.2 & $<0.5$ \\
\hline G25 & 22 & 19 & 20 & $<0.05$ & $<0.5$ & $<0.5$ & $<1$ & 2 & $<2$ & 141 & $<2$ & 0.2 & $<0.5$ \\
\hline G26 & 15 & 0.9 & 7 & $<0.05$ & $<0.5$ & $<0.5$ & $<1$ & 0.9 & $<2$ & 39 & $<2$ & $<.2$ & $<0.5$ \\
\hline G27 & $<5$ & $<0.3$ & 5 & $<0.05$ & $<0.5$ & $<0.5$ & $<1$ & $<0.5$ & $<2$ & 190 & $<2$ & $<.2$ & $<0.5$ \\
\hline G28 & 14 & 32 & 6 & $<0.05$ & $<0.5$ & $<0.5$ & $<1$ & 6 & $<2$ & 174 & $<2$ & 0.4 & $<0.5$ \\
\hline G29 & 60 & 92 & 1 & $<0.05$ & $<0.5$ & $<0.5$ & $<1$ & 1 & $<2$ & 176 & $<2$ & $<.2$ & $<0.5$ \\
\hline G30 & 8 & 0.5 & 29 & $<0.05$ & $<0.5$ & $<0.5$ & $<1$ & 2 & $<2$ & 194 & $<2$ & $<.2$ & 1.71 \\
\hline G31 & 9 & 0.4 & 16 & $<0.05$ & $<0.5$ & $<0.5$ & $<1$ & 1 & $<2$ & 111 & $<2$ & $<.2$ & $<0.5$ \\
\hline & & & & & & zoic se & ary roc & & & & & & \\
\hline G09 & 25 & 4 & 257 & $<0.05$ & $<0.5$ & $<0.5$ & 1 & 8 & $<2$ & 161 & $<2$ & 0.3 & 0.57 \\
\hline G10 & $<5$ & 0.4 & 227 & $<0.05$ & $<0.5$ & $<0.5$ & $<1$ & 11 & $<2$ & 241 & $<2$ & 0.2 & 2.71 \\
\hline G11 & $<5$ & $<0.3$ & 439 & $<0.05$ & $<0.5$ & $<0.5$ & $<1$ & 20 & $<2$ & 192 & $<2$ & 0.3 & 1.02 \\
\hline G12 & $<5$ & 2 & 274 & $<0.05$ & $<0.5$ & $<0.5$ & $<1$ & 15 & $<2$ & 205 & $<2$ & $<.2$ & $<0.5$ \\
\hline G13 & $<5$ & $<0.3$ & 274 & $<0.05$ & $<0.5$ & $<0.5$ & $<1$ & 11 & $<2$ & 535 & $<2$ & 0.3 & $<0.5$ \\
\hline & & & & & & zoic se & ary roc & & & & & & \\
\hline $\mathrm{C} 01$ & $<20$ & 0.4 & 108 & $<0.05$ & - & 0.06 & 0.63 & 14.5 & 1.2 & 142 & 0.7 & 1 & 1.0 \\
\hline $\mathrm{C} 02$ & $<20$ & 0.1 & 61.3 & $<0.05$ & - & 0.05 & $<0.5$ & 4.5 & 1.2 & 129 & 0.6 & 0.5 & 0.8 \\
\hline $\mathrm{C} 03$ & $<20$ & 0.4 & 72.9 & $<0.05$ & - & 0.06 & $<0.5$ & 2.6 & 0.9 & 56.2 & 0.1 & 0.5 & 0.9 \\
\hline $\mathrm{C} 04$ & $<20$ & 0.1 & 99.0 & $<0.05$ & - & 0.05 & $<0.5$ & 0.6 & 1.0 & 25.5 & $<0.1$ & $<0.5$ & 0.9 \\
\hline $\mathrm{C} 05$ & $<20$ & 0.2 & 169 & $<0.05$ & _ & 0.05 & $<0.5$ & 1.0 & 1.0 & 47.0 & $<0.1$ & $<0.5$ & 1.6 \\
\hline C06 & $<20$ & 0.3 & 264 & $<0.05$ & - & 0.06 & $<0.5$ & 1.6 & 1.1 & 94.5 & $<0.1$ & 0.6 & 1.8 \\
\hline $\mathrm{C} 07$ & $<20$ & 0.3 & 64.0 & $0 § 5$ & - & 0.07 & $<0.5$ & 1.2 & 1.5 & 123 & 0.8 & 0.9 & 0.9 \\
\hline $\mathrm{C} 08$ & $<20$ & 3.5 & 55.7 & $<0.05$ & - & 0.07 & $<0.5$ & 1.5 & 1.4 & 143 & 0.7 & 0.7 & 0.8 \\
\hline $\mathrm{C} 09$ & $<20$ & 0.2 & 54.6 & $<0.05$ & - & 0.10 & 0.72 & 1.8 & 2.3 & 793 & 3.1 & 0.7 & 0.7 \\
\hline $\mathrm{C} 10$ & $<20$ & 0.1 & 53.5 & $<0.05$ & - & 0.06 & 0.52 & 2.0 & 1.6 & 419 & 1.6 & 0.8 & 0.7 \\
\hline C11 & $<20$ & 0.3 & 134 & $<0.05$ & - & 0.06 & $<0.5$ & 1.6 & 1.1 & 70.0 & 0.1 & 0.6 & 1.3 \\
\hline $\mathrm{C} 16$ & $<20$ & 0.8 & 84.5 & $<0.05$ & - & 0.04 & $<0.5$ & 2.3 & 0.9 & 38.0 & $<0.1$ & $<0.5$ & 0.9 \\
\hline $\mathrm{C} 17$ & 61 & 28.8 & 73.7 & $<0.05$ & - & 0.12 & $<0.5$ & 3.5 & 1.6 & 246 & 1.1 & 4.7 & 0.9 \\
\hline C18 & 35 & 3.9 & 85.3 & $<0.05$ & - & 0.06 & $<0.5$ & 3.4 & 1.1 & 133 & 0.2 & $<0.5$ & 0.7 \\
\hline C19 & $<20$ & 3.6 & 102 & $<0.05$ & - & 0.06 & $<0.5$ & 1.2 & 1.0 & 47.5 & $<0.1$ & $<0.5$ & 0.7 \\
\hline & & & & & & $y$ and $F$ & zoic ro & & & & & & \\
\hline G21 & 35 & $<0.3$ & 5 & $<0.05$ & $<0.5$ & $<0.5$ & $<1$ & 6 & $<2$ & 36 & $<2$ & 0.6 & $<0.5$ \\
\hline G22 & 14 & $<0.3$ & 13 & $<0.05$ & $<0.5$ & $<0.5$ & $<1$ & 2 & $<2$ & 48 & $<2$ & 4 & $<0.5$ \\
\hline G23 & 10 & 0.5 & 9 & $<0.05$ & $<0.5$ & $<0.5$ & $<1$ & 2 & $<2$ & 36 & $<2$ & 5 & $<0.5$ \\
\hline G40 & 14 & 0.4 & 11 & $<0.05$ & $<0.5$ & $<0.5$ & $<1$ & 0.7 & $<2$ & 36 & $<2$ & 0.4 & $<0.5$ \\
\hline G41 & 30 & $<0.3$ & 29 & $<0.05$ & $<0.5$ & $<0.5$ & $<1$ & 2 & $<2$ & 31 & $<2$ & 0.3 & 0.51 \\
\hline G42 & 13 & $<0.3$ & 20 & $<0.05$ & $<0.5$ & $<0.5$ & $<1$ & 1 & $<2$ & 28 & $<2$ & 0.2 & $<0.5$ \\
\hline G43 & $<5$ & $<0.3$ & 3 & $<0.05$ & $<0.5$ & $<0.5$ & 1 & 1 & $<2$ & 37 & $<2$ & 0.3 & 0.57 \\
\hline G44 & 13 & $<0.3$ & 3 & $<0.05$ & $<0.5$ & $<0.5$ & $<1$ & 1 & $<2$ & 45 & $<2$ & 0.3 & $<0.5$ \\
\hline
\end{tabular}


Appendix 1- Continued. Chemical analyses of stream and spring water samples from watersheds underlain by the ten dominant rock composition types in the Grand Mesa, Uncompahgre, and Gunnison National Forests, Colorado.

\begin{tabular}{|c|c|c|c|c|c|c|c|c|c|c|c|c|c|}
\hline Sample no. & $\begin{array}{c}\mathrm{Sc} \\
\mu \mathrm{g} / \mathrm{L}\end{array}$ & $\begin{array}{c}\mathrm{Cr} \\
\mu \mathrm{g} / \mathrm{L}\end{array}$ & $\begin{array}{c}\mathrm{Ga} \\
\mu \mathrm{g} / \mathrm{L}\end{array}$ & $\begin{array}{c}\text { As } \\
\mu \mathrm{g} / \mathrm{L}\end{array}$ & $\begin{array}{c}\mathrm{Se} \\
\mu \mathrm{g} / \mathrm{L}\end{array}$ & $\begin{array}{c}\mathrm{Br} \\
\mu \mathrm{g} / \mathrm{L}\end{array}$ & $\begin{array}{c}\mathrm{Rb} \\
\mu \mathrm{g} / \mathrm{L}\end{array}$ & $\begin{array}{c}\mathrm{Y} \\
\mu \mathrm{g} / \mathrm{L}\end{array}$ & $\begin{array}{c}\mathrm{Zr} \\
\mu \mathrm{g} / \mathrm{L}\end{array}$ & $\begin{array}{c}\mathrm{Mo} \\
\mu \mathrm{g} / \mathrm{L}\end{array}$ & $\begin{array}{c}\mathrm{Sn} \\
\mu \mathrm{g} / \mathrm{L}\end{array}$ & $\begin{array}{c}\mathrm{Sb} \\
\mu \mathrm{g} / \mathrm{L}\end{array}$ & $\begin{array}{c}1 \\
\mu \mathrm{g} / \mathrm{L}\end{array}$ \\
\hline & & & & & & Tertia & salt & & & & & & \\
\hline G14 & 17 & $<0.1$ & $<0.01$ & $<0.03$ & $<0.2$ & $<3$ & 0.294 & 0.31 & 0.282 & 0.53 & $<0.05$ & $<0.01$ & $<0.2$ \\
\hline G15 & 21 & $<0.1$ & $<0.01$ & 0.7 & $<0.2$ & $<3$ & 0.350 & 0.44 & 0.431 & $<0.5$ & 1.913 & 0.22 & 19.64 \\
\hline G16 & 26 & $<0.1$ & $<0.01$ & $<0.03$ & $<0.2$ & $<3$ & 1.340 & 0.53 & 1.027 & $<0.5$ & $<0.05$ & $<0.01$ & 2.05 \\
\hline G17 & 22 & $<0.1$ & $<0.01$ & $<0.03$ & $<0.2$ & $<3$ & 0.438 & 0.38 & 0.277 & $<0.5$ & $<0.05$ & $<0.01$ & $<0.2$ \\
\hline & & & & & & rtiary & ow tuff & & & & & & \\
\hline G45 & 48 & $<0.1$ & $<0.01$ & 0.9 & $<0.2$ & 33 & 0.764 & 0.08 & 0.220 & $<0.5$ & $<0.05$ & 0.09 & 7.82 \\
\hline G46 & 51 & $<0.1$ & $<0.01$ & 2.2 & $<0.2$ & $<3$ & 2.248 & 0.08 & 0.843 & 0.60 & $<0.05$ & 0.13 & 5.17 \\
\hline G56 & 35 & $<0.1$ & $<0.01$ & 1.5 & $<0.2$ & $<3$ & 0.327 & 0.05 & 8.512 & $<0.5$ & $<0.05$ & $<0.01$ & 3.51 \\
\hline G57 & 25 & $<0.1$ & $<0.01$ & 0.9 & $<0.2$ & $<3$ & 3.118 & 0.14 & 0.124 & $<0.5$ & $<0.05$ & $<0.01$ & $<0.2$ \\
\hline G58 & 22 & $<0.1$ & $<0.01$ & 0.8 & $<0.2$ & $<3$ & 1.609 & 0.18 & 0.178 & $<0.5$ & $<0.05$ & $<0.01$ & 2.51 \\
\hline & & & & & & rtiary & z latite & & & & & & \\
\hline C12 & 1.9 & $<1$ & $<0.02$ & - & - & - & 3.05 & 0.10 & 0.08 & 0.26 & - & $<0.1$ & - \\
\hline $\mathrm{C} 13$ & 5.3 & $<1$ & 0.1 & - & - & - & 1.51 & 1.49 & 1.4 & 0.82 & - & $<0.1$ & - \\
\hline C14 & 2.5 & $<1$ & 0.02 & - & - & - & 0.85 & 0.28 & 0.3 & 1.08 & - & $<0.1$ & - \\
\hline $\mathrm{C} 15$ & 2.8 & $<1$ & $<0.02$ & - & - & - & 1.07 & 0.24 & 0.3 & 0.37 & - & $<0.1$ & - \\
\hline & & & & & & Tertiar & esite & & & & & & \\
\hline G47 & 26 & $<0.1$ & $<0.01$ & 0.4 & $<0.2$ & $<3$ & 1.420 & 0.07 & 0.171 & $<0.5$ & $<0.05$ & $<0.01$ & $<0.2$ \\
\hline G48 & 42 & $<0.1$ & $<0.01$ & 0.7 & $<0.2$ & $<3$ & 1.712 & 0.07 & 0.426 & $<0.5$ & $<0.05$ & $<0.01$ & $<0.2$ \\
\hline G49 & 37 & $<0.1$ & $<0.01$ & 0.6 & $<0.2$ & $<3$ & 2.122 & 0.10 & 0.277 & $<0.5$ & $<0.05$ & 0.07 & $<0.2$ \\
\hline G50 & 41 & $<0.1$ & $<0.01$ & 0.6 & $<0.2$ & $<3$ & 3.165 & 0.11 & 0.153 & $<0.5$ & $<0.05$ & 0.06 & $<0.2$ \\
\hline G51 & 37 & $<0.1$ & $<0.01$ & 1.3 & $<0.2$ & $<3$ & 2.032 & 0.07 & 0.256 & 0.53 & $<0.05$ & $<0.01$ & $<0.2$ \\
\hline G52 & 48 & $<0.1$ & $<0.01$ & 0.8 & $<0.2$ & $<3$ & 2.759 & 0.06 & 0.374 & 0.59 & $<0.05$ & $<0.01$ & $<0.2$ \\
\hline G54 & 54 & $<0.1$ & $<0.01$ & 0.5 & $<0.2$ & $<3$ & 3.717 & 0.05 & 0.227 & $<0.5$ & $<0.05$ & $<0.01$ & $<0.2$ \\
\hline G55 & 51 & $<0.1$ & $<0.01$ & 1.0 & $<0.2$ & $<3$ & 3.705 & 0.05 & 0.449 & $<0.5$ & $<0.05$ & $<0.01$ & 2.16 \\
\hline & & & & & & ary se & tary roc & & & & & & \\
\hline G01 & 11 & $<0.1$ & $<0.01$ & 1.3 & $<0.2$ & 90 & 0.658 & 0.17 & 1.256 & 0.53 & $<0.05$ & 0.17 & 35.69 \\
\hline G02 & 27 & $<0.1$ & $<0.01$ & 1.4 & $<0.2$ & 182 & 0.840 & 0.06 & 0.762 & 2.10 & $<0.05$ & 0.26 & 24.76 \\
\hline G03 & 25 & $<0.1$ & $<0.01$ & 2.4 & $<0.2$ & $<3$ & 0.569 & 0.07 & 0.182 & 3.28 & $<0.05$ & 0.13 & 2.45 \\
\hline G04 & 27 & $<0.1$ & $<0.01$ & 4.1 & $<0.2$ & $<3$ & 0.490 & 0.06 & 0.685 & 2.51 & $<0.05$ & 0.26 & $<0.2$ \\
\hline G05 & 35 & $<0.1$ & $<0.01$ & 5.8 & $<0.2$ & $<3$ & 0.600 & 0.05 & 0.220 & 7.48 & $<0.05$ & 0.29 & $<0.2$ \\
\hline G06 & 36 & $<0.1$ & $<0.01$ & 0.6 & $<0.2$ & $<3$ & 0.733 & 0.10 & 0.139 & 1.54 & $<0.05$ & 0.09 & $<0.2$ \\
\hline G07 & 24 & $<0.1$ & $<0.01$ & 1.3 & $<0.2$ & $<3$ & 0.403 & 0.12 & 0.628 & 0.82 & $<0.05$ & $<0.01$ & 2.27 \\
\hline & & & & & Cre & us $\mathrm{Me}$ & de Forn & & & & & & \\
\hline G32 & 19 & $<0.1$ & $<0.01$ & $<0.03$ & $<0.2$ & $<3$ & 0.398 & 0.04 & 0.623 & $<0.5$ & $<0.05$ & $<0.01$ & $<0.2$ \\
\hline G33 & 16 & $<0.1$ & $<0.01$ & 0.3 & $<0.2$ & $<3$ & 0.306 & 0.04 & 0.116 & $<0.5$ & $<0.05$ & $<0.01$ & $<0.2$ \\
\hline G34 & 17 & $<0.1$ & $<0.01$ & $<0.03$ & $<0.2$ & $<3$ & 0.136 & $<0.03$ & 0.241 & $<0.5$ & $<0.05$ & $<0.01$ & $<0.2$ \\
\hline G35 & 21 & $<0.1$ & $<0.01$ & $<0.03$ & $<0.2$ & $<3$ & 0.350 & 0.03 & 0.485 & $<0.5$ & $<0.05$ & $<0.01$ & $<0.2$ \\
\hline G36 & 17 & $<0.1$ & $<0.01$ & 2.4 & $<0.2$ & $<3$ & 0.447 & 0.04 & $<0.05$ & $<0.5$ & $<0.05$ & $<0.01$ & $<0.2$ \\
\hline G37 & 19 & $<0.1$ & $<0.01$ & $<0.03$ & $<0.2$ & $<3$ & 0.429 & 0.04 & $<0.05$ & $<0.5$ & $<0.05$ & $<0.01$ & $<0.2$ \\
\hline G38 & 18 & $<0.1$ & $<0.01$ & 0.6 & $<0.2$ & $<3$ & 0.365 & 0.06 & 0.057 & 0.63 & $<0.05$ & $<0.01$ & $<0.2$ \\
\hline G39 & 18 & $<0.1$ & $<0.01$ & $<0.03$ & $<0.2$ & $<3$ & 0.279 & 0.12 & 0.500 & $<0.5$ & $<0.05$ & $<0.01$ & $<0.2$ \\
\hline & & & & & & ceous & $\cos$ Sha & & & & & & \\
\hline G19 & 28 & $<0.1$ & $<0.01$ & 0.4 & $<0.2$ & $<3$ & 0.071 & 0.04 & 0.415 & 0.80 & $<0.05$ & -0.01 & 2.32 \\
\hline G20 & 35 & $<0.1$ & $<0.01$ & 0.3 & $<0.2$ & $<3$ & 0.078 & 0.04 & $<0.05$ & 0.72 & $<0.05$ & 0.01 & 3.63 \\
\hline G24 & 17 & $<0.1$ & $<0.01$ & 0.5 & $<0.2$ & $<3$ & 0.227 & 0.04 & 0.141 & 0.80 & $<0.05$ & 0.07 & 3.85 \\
\hline G25 & 14 & $<0.1$ & $<0.01$ & 0.4 & $<0.2$ & $<3$ & 0.249 & 0.09 & $<0.05$ & 0.81 & $<0.05$ & 0.14 & $<0.2$ \\
\hline G26 & 15 & $<0.1$ & 0.013 & $<0.03$ & $<0.2$ & $<3$ & 0.153 & 0.06 & 0.069 & $<0.5$ & $<0.05$ & 0.06 & $<0.2$ \\
\hline G27 & 17 & $<0.1$ & $<0.01$ & $<0.03$ & $<0.2$ & $<3$ & 0.052 & 0.03 & 0.070 & $<0.5$ & $<0.05$ & $<0.01$ & $<0.2$ \\
\hline G28 & 15 & $<0.1$ & $<0.01$ & $<0.03$ & $<0.2$ & $<3$ & 0.653 & 0.13 & 0.064 & 1.35 & $<0.05$ & 0.01 & $<0.2$ \\
\hline G29 & 23 & $<0.1$ & $<0.01$ & 0.5 & $<0.2$ & $<3$ & 0.230 & 0.05 & 0.073 & 1.28 & $<0.05$ & $<0.01$ & 3.24 \\
\hline G30 & 24 & $<0.1$ & $<0.01$ & 0.3 & $<0.2$ & $<3$ & 0.238 & 0.05 & 0.055 & 1.74 & $<0.05$ & $<0.01$ & $<0.2$ \\
\hline G31 & 15 & $<0.1$ & $<0.01$ & $<0.03$ & $<0.2$ & $<3$ & 0.163 & 0.06 & $<0.05$ & $<0.5$ & $<0.05$ & $<0.01$ & $<0.2$ \\
\hline & & & & & & zoic s & ntary ro & & & & & & \\
\hline G09 & 11 & $<0.1$ & $<0.01$ & 2.8 & $<0.2$ & $<3$ & 1.508 & 0.03 & 0.241 & 0.65 & $<0.05$ & 0.01 & 2.67 \\
\hline G10 & 21 & $<0.1$ & $<0.01$ & 2.0 & $<0.2$ & 78 & 2.741 & $<0.03$ & 0.083 & $<0.5$ & $<0.05$ & $<0.01$ & 5.53 \\
\hline G11 & 12 & $<0.1$ & $<0.01$ & 1.8 & 2.71 & 51 & 4.048 & $<0.03$ & 0.440 & $<0.5$ & $<0.05$ & 0.09 & 2.78 \\
\hline G12 & 12 & $<0.1$ & $<0.01$ & 0.3 & $<0.2$ & $<3$ & 3.455 & $<0.03$ & 0.232 & $<0.5$ & $<0.05$ & $<0.01$ & $<0.2$ \\
\hline G13 & 25 & $<0.1$ & $<0.01$ & 0.6 & $<0.2$ & $<3$ & 1.466 & 0.20 & $<0.05$ & $<0.5$ & $<0.05$ & 0.06 & $<0.2$ \\
\hline & & & & & & zoic s & ntary ro & & & & & & \\
\hline C01 & 0.9 & 3.2 & $<0.02$ & - & - & - & 3.05 & 0.02 & $<0.05$ & 0.68 & - & 0.20 & - \\
\hline $\mathrm{C} 02$ & 1.0 & 3.4 & $<0.02$ & - & - & - & 0.88 & $<0.01$ & $<0.05$ & 0.91 & - & $<0.1$ & - \\
\hline $\mathrm{C} 03$ & 0.9 & 2.7 & $<0.02$ & - & - & - & 0.53 & 0.02 & $<0.05$ & 0.48 & - & $<0.1$ & - \\
\hline C04 & 0.7 & 2.2 & $<0.02$ & - & - & - & 0.18 & 0.08 & $<0.05$ & $<0.2$ & - & $<0.1$ & - \\
\hline $\mathrm{C} 05$ & 1.0 & 2.1 & $<0.02$ & - & - & - & 0.16 & 0.04 & $<0.05$ & $<0.2$ & - & $<0.1$ & - \\
\hline C06 & 0.9 & 2.3 & $<0.02$ & - & - & - & 0.32 & 0.05 & $<0.05$ & $<0.2$ & - & $<0.1$ & - \\
\hline C07 & 0.8 & 3.2 & $<0.02$ & - & - & - & 0.05 & 0.03 & $<0.05$ & 0.73 & - & $<0.1$ & - \\
\hline $\mathrm{C} 08$ & 0.6 & 2.7 & $<0.02$ & - & - & - & 0.11 & 0.02 & $<0.05$ & 0.66 & - & $<0.1$ & - \\
\hline $\mathrm{C} 09$ & 0.6 & 2.3 & $<0.02$ & - & - & - & 0.49 & 0.10 & $<0.05$ & 0.84 & - & $<0.1$ & - \\
\hline $\mathrm{C} 10$ & 0.7 & 2.7 & $<0.02$ & - & - & - & 0.61 & 0.03 & $<0.05$ & 1.46 & - & $<0.1$ & - \\
\hline $\mathrm{C} 11$ & 0.8 & 2.6 & $<0.02$ & - & - & - & 0.21 & 0.04 & $<0.05$ & 0.26 & - & $<0.1$ & - \\
\hline C16 & 1.1 & 2.1 & $<0.02$ & - & - & - & 3.13 & 0.05 & $<0.05$ & $<0.2$ & - & $<0.1$ & - \\
\hline $\mathrm{C} 17$ & 1.1 & 3.1 & $<0.02$ & - & - & - & 1.02 & 0.04 & $<0.05$ & 0.45 & - & $<0.1$ & - \\
\hline C18 & 1.3 & 2.3 & $<0.02$ & - & - & - & 2.10 & 0.03 & $<0.05$ & 0.51 & - & $<0.1$ & - \\
\hline C19 & 0.7 & 2.1 & $<0.02$ & - & - & - & 0.39 & 0.04 & $<0.05$ & 0.25 & - & $<0.1$ & - \\
\hline & & & & & & $y$ and & rozoic $r$ & & & & & & \\
\hline G21 & 30 & $<0.1$ & $<0.01$ & $<0.03$ & $<0.2$ & $<3$ & 0.121 & 0.77 & 0.571 & $<0.5$ & $<0.05$ & $<0.01$ & 3.16 \\
\hline G22 & 22 & $<0.1$ & $<0.01$ & $<0.03$ & $<0.2$ & $<3$ & 1.489 & 0.17 & 0.084 & $<0.5$ & $<0.05$ & $<0.01$ & $<0.2$ \\
\hline G23 & 28 & $<0.1$ & $<0.01$ & $<0.03$ & $<0.2$ & $<3$ & 0.720 & $<0.03$ & 0.175 & 0.72 & $<0.05$ & $<0.01$ & $<0.2$ \\
\hline G40 & 20 & $<0.1$ & $<0.01$ & $<0.03$ & $<0.2$ & $<3$ & 0.187 & 0.65 & 0.366 & 1.26 & $<0.05$ & $<0.01$ & $<0.2$ \\
\hline G41 & 26 & $<0.1$ & $<0.01$ & $<0.03$ & $<0.2$ & $<3$ & 0.247 & 0.37 & 0.110 & 1.40 & 1.475 & 0.13 & $<0.2$ \\
\hline G42 & 24 & $<0.1$ & $<0.01$ & $<0.03$ & $<0.2$ & $<3$ & 0.182 & 0.77 & 0.085 & 2.90 & $<0.05$ & $<0.01$ & $<0.2$ \\
\hline G43 & 13 & $<0.1$ & 0.011 & $<0.03$ & $<0.2$ & $<3$ & 0.336 & 0.03 & 12.503 & $<0.5$ & $<0.05$ & $<0.01$ & $<0.2$ \\
\hline G44 & -10 & $<0.1$ & $<0.01$ & $<0.03$ & $<0.2$ & $<3$ & 0.636 & 0.04 & 0.678 & 2.21 & $<0.05$ & 0.15 & $<0.2$ \\
\hline
\end{tabular}


Appendix 1- Continued. Chemical analyses of stream and spring water samples from watersheds underlain by the ten dominant rock composition types in the Grand Mesa, Uncompahgre, and Gunnison National Forests, Colorado.

\begin{tabular}{|c|c|c|c|c|c|c|c|c|c|c|c|c|c|}
\hline Sample no. & $\begin{array}{c}\mathrm{Cs} \\
\mu \mathrm{g} / \mathrm{L}\end{array}$ & $\begin{array}{c}\mathrm{La} \\
\mu \mathrm{g} / \mathrm{L}\end{array}$ & $\begin{array}{c}\mathrm{Ce} \\
\mu \mathrm{g} / \mathrm{L}\end{array}$ & $\begin{array}{c}\mathrm{Pr} \\
\mu \mathrm{g} / \mathrm{L}\end{array}$ & $\begin{array}{c}\mathrm{Nd} \\
\mu \mathrm{g} / \mathrm{L}\end{array}$ & $\begin{array}{c}\mathrm{Sm} \\
\mu \mathrm{g} / \mathrm{L}\end{array}$ & $\begin{array}{c}\mathrm{Eu} \\
\mu \mathrm{g} / \mathrm{L}\end{array}$ & $\begin{array}{c}\mathrm{Gd} \\
\mu \mathrm{g} / \mathrm{L}\end{array}$ & $\begin{array}{c}\mathrm{Tb} \\
\mu \mathrm{g} / \mathrm{L}\end{array}$ & $\begin{array}{c}\text { Dy } \\
\mu \mathrm{g} / \mathrm{L}\end{array}$ & $\begin{array}{c}\mathrm{Ho} \\
\mu \mathrm{g} / \mathrm{L}\end{array}$ & $\begin{array}{c}\mathrm{Er} \\
\mu \mathrm{g} / \mathrm{L}\end{array}$ & $\begin{array}{c}\mathrm{Tm} \\
\mu \mathrm{g} / \mathrm{L}\end{array}$ \\
\hline & & & & & & Tertia & basalt & & & & & & \\
\hline G14 & $<0.002$ & 0.262 & 0.563 & 0.076 & 0.331 & 0.053 & 0.025 & 0.132 & $<0.001$ & 0.048 & $<0.001$ & 0.036 & $<0.001$ \\
\hline G15 & $<0.002$ & 0.313 & 0.500 & 0.103 & 0.425 & 0.063 & 0.037 & 0.105 & 0.014 & 0.088 & $<0.001$ & 0.057 & $<0.001$ \\
\hline G16 & $<0.002$ & 0.264 & 0.379 & 0.067 & 0.314 & 0.040 & 0.031 & 0.136 & 0.021 & 0.078 & 0.019 & 0.043 & $<0.001$ \\
\hline G17 & $<0.002$ & 0.174 & 0.321 & 0.050 & 0.335 & 0.053 & 0.017 & 0.060 & $<0.001$ & 0.037 & $<0.001$ & 0.029 & $<0.001$ \\
\hline & & & & & & Tertiary & flow tuf & & & & & & \\
\hline G45 & $<0.002$ & $<0.005$ & $<0.005$ & $<0.002$ & 0.054 & -0.001 & $<0.001$ & 0.020 & 0.001 & 0.011 & $<0.001$ & $<0.001$ & 0.001 \\
\hline G46 & $<0.002$ & 0.068 & 0.142 & $<0.002$ & $<0.004$ & -0.001 & $<0.001$ & 0.026 & $<0.001$ & $<0.001$ & $<0.001$ & $<0.001$ & $<0.001$ \\
\hline G56 & $<0.002$ & $<0.005$ & $<0.005$ & $<0.002$ & $<0.004$ & 0.012 & $<0.001$ & 0.027 & $<0.001$ & $<0.001$ & $<0.001$ & $<0.001$ & $<0.001$ \\
\hline G57 & $<0.002$ & 0.075 & 0.143 & 0.026 & 0.143 & $<0.001$ & $<0.001$ & 0.038 & $<0.001$ & 0.011 & $<0.001$ & 0.011 & $<0.001$ \\
\hline G58 & $<0.002$ & 0.165 & 0.304 & 0.034 & 0.123 & $<0.001$ & $<0.001$ & 0.038 & $<0.001$ & 0.022 & $<0.001$ & 0.014 & $<0.001$ \\
\hline & & & & & & Tertiary & artz latite & & & & & & \\
\hline $\mathrm{C} 12$ & 0.01 & 0.05 & 0.06 & 0.01 & 0.06 & 0.01 & 0.005 & 0.009 & $<0.005$ & 0.02 & $<0.005$ & 0.01 & $<0.005$ \\
\hline $\mathrm{C} 13$ & 0.05 & 0.49 & 0.55 & 0.14 & 0.67 & 0.13 & 0.03 & 0.19 & 0.03 & 0.17 & 0.04 & 0.16 & 0.02 \\
\hline $\mathrm{C} 14$ & 0.01 & 0.12 & 0.16 & 0.04 & 0.14 & 0.02 & $<0.005$ & 0.04 & 0.006 & 0.04 & 0.009 & 0.03 & $<0.005$ \\
\hline $\mathrm{C} 15$ & 0.13 & 0.11 & 0.17 & 0.03 & 0.17 & 0.03 & 0.006 & 0.04 & $<0.005$ & 0.03 & 0.008 & 0.02 & $<0.005$ \\
\hline & & & & & & Tertiar & andesite & & & & & & \\
\hline G47 & $<0.002$ & $<0.005$ & $<0.005$ & $<0.002$ & 0.054 & $<0.001$ & $<0.001$ & 0.020 & $<0.001$ & $<0.001$ & $<0.001$ & $<0.001$ & $<0.001$ \\
\hline G48 & $<0.002$ & $<0.005$ & 0.055 & $<0.002$ & $<0.004$ & $<0.001$ & $<0.001$ & $<0.001$ & $<0.001$ & $<0.001$ & $<0.001$ & 0.027 & $<0.001$ \\
\hline G49 & $<0.002$ & $<0.005$ & 0.069 & $<0.002$ & 0.074 & $<0.001$ & $<0.001$ & 0.026 & $<0.001$ & $<0.001$ & $<0.001$ & 0.011 & $<0.001$ \\
\hline G50 & $<0.002$ & $<0.005$ & 0.063 & $<0.002$ & 0.087 & 0.018 & $<0.001$ & $<0.001$ & $<0.001$ & $<0.001$ & $<0.001$ & 0.030 & $<0.001$ \\
\hline G51 & $<0.002$ & $<0.005$ & 0.052 & $<0.002$ & $<0.004$ & 0.011 & $<0.001$ & 0.026 & $<0.001$ & $<0.001$ & $<0.001$ & 0.014 & $<0.001$ \\
\hline G52 & $<0.002$ & $<0.005$ & $<0.005$ & $<0.002$ & $<0.004$ & $<0.001$ & $<0.001$ & 0.044 & $<0.001$ & $<0.001$ & $<0.001$ & $<0.001$ & $<0.001$ \\
\hline G54 & $<0.002$ & $<0.005$ & $<0.005$ & $<0.002$ & 0.043 & 0.012 & $<0.001$ & 0.033 & $<0.001$ & 0.023 & $<0.001$ & $<0.001$ & $<0.001$ \\
\hline G55 & $<0.002$ & $<0.005$ & 0.053 & $<0.002$ & $<0.004$ & $<0.001$ & $<0.001$ & 0.039 & $<0.001$ & $<0.001$ & $<0.001$ & $<0.001$ & $<0.001$ \\
\hline & & & & & & ertiary se & entary $\mathrm{rc}$ & & & & & & \\
\hline G01 & 0.002 & 0.072 & 0.128 & 0.050 & 0.138 & 0.028 & 0.153 & 0.054 & 0.041 & 0.040 & 0.027 & 0.038 & 0.026 \\
\hline G02 & $<0.002$ & $<0.005$ & 0.283 & 0.037 & 0.153 & 0.027 & 0.071 & 0.088 & 0.019 & 0.024 & 0.018 & $<0.001$ & 0.018 \\
\hline G03 & $<0.002$ & 0.051 & 0.108 & 0.002 & 0.064 & $<0.001$ & 0.025 & $<0.001$ & $<0.001$ & 0.032 & $<0.001$ & 0.013 & $<0.001$ \\
\hline G04 & $<0.002$ & 0.071 & 0.052 & 0.023 & 0.082 & 0.022 & $<0.001$ & $<0.001$ & $<0.001$ & $<0.001$ & $<0.001$ & $<0.001$ & $<0.001$ \\
\hline G05 & $<0.002$ & $<0.005$ & $<0.005$ & $<0.002$ & 0.040 & 0.016 & 0.030 & 0.037 & $<0.001$ & $<0.001$ & $<0.001$ & 0.011 & $<0.001$ \\
\hline G06 & $<0.002$ & $<0.005$ & 0.134 & $<0.002$ & 0.083 & 0.016 & 0.015 & $<0.001$ & $<0.001$ & 0.025 & $<0.001$ & 0.021 & $<0.001$ \\
\hline G07 & $<0.002$ & $<0.005$ & 0.110 & $<0.002$ & 0.059 & $<0.001$ & 0.048 & 0.025 & $<0.001$ & 0.025 & $<0.001$ & 0.016 & $<0.001$ \\
\hline & & & & & & ceous $\mathrm{Me}$ & verde For & & & & & & \\
\hline G32 & $<0.002$ & $<0.005$ & $<0.005$ & $<0.002$ & 0.047 & $<0.001$ & $<0.001$ & 0.014 & $<0.001$ & $<0.001$ & $<0.001$ & $<0.001$ & $<0.001$ \\
\hline G33 & $<0.002$ & $<0.005$ & $<0.005$ & $<0.002$ & $<0.004$ & $<0.001$ & $<0.001$ & $<0.001$ & $<0.001$ & 0.020 & $<0.001$ & $<0.001$ & $<0.001$ \\
\hline G34 & $<0.002$ & $<0.005$ & $<0.005$ & $<0.002$ & $<0.004$ & $<0.001$ & 0.010 & $<0.001$ & $<0.001$ & $<0.001$ & $<0.001$ & $<0.001$ & $<0.001$ \\
\hline G35 & $<0.002$ & $<0.005$ & $<0.005$ & $<0.002$ & 0.044 & $<0.001$ & $<0.001$ & 0.021 & $<0.001$ & $<0.001$ & $<0.001$ & $<0.001$ & $<0.001$ \\
\hline G36 & $<0.002$ & $<0.005$ & 0.051 & $<0.002$ & $<0.004$ & $<0.001$ & 0.012 & 0.021 & $<0.001$ & $<0.001$ & $<0.001$ & $<0.001$ & $<0.001$ \\
\hline G37 & $<0.002$ & $<0.005$ & $<0.005$ & $<0.002$ & $<0.004$ & $<0.001$ & $<0.001$ & 0.022 & $<0.001$ & $<0.001$ & $<0.001$ & $<0.001$ & $<0.001$ \\
\hline G38 & $<0.002$ & $<0.005$ & $<0.005$ & $<0.002$ & 0.058 & $<0.001$ & $<0.001$ & 0.029 & $<0.001$ & $<0.001$ & $<0.001$ & $<0.001$ & $<0.001$ \\
\hline G39 & $<0.002$ & 0.089 & 0.086 & $<0.002$ & 0.145 & 0.013 & $<0.001$ & 0.016 & $<0.001$ & 0.020 & $<0.001$ & $<0.001$ & $<0.001$ \\
\hline & & & & & & retaceous & ancos Sh & & & & & & \\
\hline G19 & $<0.002$ & $<0.005$ & $<0.005$ & $<0.002$ & 0.055 & $<0.001$ & $<0.001$ & 0.014 & $<0.001$ & $<0.001$ & $<0.001$ & $<0.001$ & $<0.001$ \\
\hline G20 & $<0.002$ & $<0.005$ & $<0.005$ & $<0.002$ & $<0.004$ & $<0.001$ & $<0.001$ & $<0.001$ & $<0.001$ & $<0.001$ & $<0.001$ & $<0.001$ & $<0.001$ \\
\hline G24 & $<0.002$ & $<0.005$ & $<0.005$ & $<0.002$ & 0.063 & 0.025 & $<0.001$ & $<0.001$ & $<0.001$ & $<0.001$ & $<0.001$ & $<0.001$ & $<0.001$ \\
\hline G25 & $<0.002$ & $<0.005$ & $<0.005$ & $<0.002$ & $<0.004$ & $<0.001$ & $<0.001$ & $<0.001$ & $<0.001$ & $<0.001$ & $<0.001$ & $<0.001$ & $<0.001$ \\
\hline G26 & $<0.002$ & $<0.005$ & $<0.005$ & $<0.002$ & 0.042 & $<0.001$ & $<0.001$ & $<0.001$ & $<0.001$ & $<0.001$ & $<0.001$ & $<0.001$ & $<0.001$ \\
\hline G27 & $<0.002$ & $<0.005$ & $<0.005$ & $<0.002$ & $<0.004$ & $<0.001$ & $<0.001$ & 0.014 & $<0.001$ & $<0.001$ & $<0.001$ & $<0.001$ & $<0.001$ \\
\hline G28 & $<0.002$ & $<0.005$ & $<0.005$ & $<0.002$ & $<0.004$ & 0.012 & $<0.001$ & 0.034 & $<0.001$ & $<0.001$ & $<0.001$ & $<0.001$ & $<0.001$ \\
\hline G29 & $<0.002$ & $<0.005$ & $<0.005$ & $<0.002$ & $<0.004$ & 0.012 & $<0.001$ & $<0.001$ & $<0.001$ & $<0.001$ & $<0.001$ & $<0.001$ & $<0.001$ \\
\hline G30 & $<0.002$ & $<0.005$ & $<0.005$ & $<0.002$ & 0.063 & $<0.001$ & $<0.001$ & 0.015 & $<0.001$ & $<0.001$ & $<0.001$ & $<0.001$ & $<0.001$ \\
\hline G31 & $<0.002$ & $<0.005$ & $<0.005$ & $<0.002$ & 0.081 & $<0.001$ & $<0.001$ & 0.021 & $<0.001$ & 0.011 & $<0.001$ & $<0.001$ & $<0.001$ \\
\hline & & & & & & esozoic s & mentary & & & & & & \\
\hline G09 & $<0.002$ & $<0.005$ & $<0.005$ & $<0.002$ & 0.052 & $<0.001$ & 0.142 & 0.013 & $<0.001$ & $<0.001$ & $<0.001$ & 0.011 & $<0.001$ \\
\hline G10 & 0.297 & $<0.005$ & $<0.005$ & $<0.002$ & $<0.004$ & $<0.001$ & 0.109 & 0.025 & $<0.001$ & $<0.001$ & $<0.001$ & $<0.001$ & $<0.001$ \\
\hline G11 & 0.311 & $<0.005$ & $<0.005$ & $<0.002$ & $<0.004$ & $<0.001$ & 0.258 & $<0.001$ & $<0.001$ & $<0.001$ & $<0.001$ & $<0.001$ & $<0.001$ \\
\hline G12 & 0.107 & $<0.005$ & $<0.005$ & $<0.002$ & $<0.004$ & $<0.001$ & 0.116 & 0.031 & $<0.001$ & $<0.001$ & $<0.001$ & $<0.001$ & $<0.001$ \\
\hline G13 & 0.037 & 0.064 & $<0.005$ & $<0.002$ & 0.072 & 0.023 & 0.110 & 0.032 & $<0.001$ & 0.010 & $<0.001$ & $<0.001$ & $<0.001$ \\
\hline & & & & & & leozoic s & mentary & & & & & & \\
\hline $\mathrm{C} 01$ & 0.12 & 0.01 & 0.02 & $<0.01$ & $<0.01$ & $<0.01$ & 0.007 & $<0.005$ & $<0.005$ & 0.006 & $<0.005$ & $<0.005$ & $<0.005$ \\
\hline $\mathrm{C} 02$ & $<0.01$ & $<0.01$ & $<0.01$ & $<0.01$ & $<0.01$ & $<0.01$ & 0.005 & $<0.005$ & $<0.005$ & $<0.005$ & $<0.005$ & $<0.005$ & $<0.005$ \\
\hline $\mathrm{C} 03$ & $<0.01$ & $<0.01$ & 0.01 & $<0.01$ & $<0.01$ & $<0.01$ & 0.008 & 0.005 & $<0.005$ & $<0.005$ & $<0.005$ & $<0.005$ & $<0.005$ \\
\hline $\mathrm{C} 04$ & $<0.01$ & 0.02 & $<0.01$ & $<0.01$ & 0.02 & 0.01 & 0.01 & 0.006 & $<0.005$ & 0.01 & $<0.005$ & $<0.005$ & $<0.005$ \\
\hline $\mathrm{C} 05$ & $<0.01$ & 0.02 & $<0.01$ & $<0.01$ & 0.02 & $<0.01$ & 0.02 & $<0.005$ & $<0.005$ & $<0.005$ & $<0.005$ & $<0.005$ & $<0.005$ \\
\hline $\mathrm{C} 06$ & $<0.01$ & 0.02 & $<0.01$ & $<0.01$ & 0.02 & $<0.01$ & 0.02 & $<0.005$ & $<0.005$ & $<0.005$ & $<0.005$ & $<0.005$ & $<0.005$ \\
\hline $\mathrm{C} 07$ & $<0.01$ & $<0.01$ & $<0.01$ & $<0.01$ & 0.01 & $<0.01$ & $<0.005$ & $<0.005$ & $<0.005$ & $<0.005$ & $<0.005$ & $<0.005$ & $<0.005$ \\
\hline $\mathrm{C} 08$ & $<0.01$ & $<0.01$ & $<0.01$ & $<0.01$ & $<0.01$ & $<0.01$ & $<0.005$ & $<0.005$ & $<0.005$ & $<0.005$ & $<0.005$ & $<0.005$ & $<0.005$ \\
\hline $\mathrm{C} 09$ & $<0.01$ & 0.01 & $<0.01$ & $<0.01$ & $<0.01$ & $<0.01$ & $<0.005$ & $<0.005$ & $<0.005$ & $<0.005$ & $<0.005$ & $<0.005$ & $<0.005$ \\
\hline $\mathrm{C} 10$ & $<0.01$ & $<0.01$ & $<0.01$ & $<0.01$ & $<0.01$ & $<0.01$ & $<0.005$ & $<0.005$ & $<0.005$ & $<0.005$ & $<0.005$ & $<0.005$ & $<0.005$ \\
\hline $\mathrm{C} 11$ & $<0.01$ & $<0.01$ & $<0.01$ & $<0.01$ & 0.01 & $<0.01$ & 0.01 & $<0.005$ & $<0.005$ & $<0.005$ & $<0.005$ & $<0.005$ & $<0.005$ \\
\hline $\mathrm{C} 16$ & 0.06 & $<0.01$ & $<0.01$ & $<0.01$ & $<0.01$ & $<0.01$ & 0.006 & $<0.005$ & $<0.005$ & $<0.005$ & $<0.005$ & $<0.005$ & $<0.005$ \\
\hline $\mathrm{C} 17$ & $<0.01$ & $<0.01$ & 0.02 & $<0.01$ & 0.01 & $<0.01$ & 0.007 & $<0.005$ & $<0.005$ & 0.005 & $<0.005$ & $<0.005$ & $<0.005$ \\
\hline $\mathrm{C} 18$ & $<0.01$ & $<0.01$ & $<0.01$ & $<0.01$ & 0.01 & $<0.01$ & 0.009 & $<0.005$ & $<0.005$ & $<0.005$ & $<0.005$ & $<0.005$ & $<0.005$ \\
\hline C19 & $<0.01$ & $<0.01$ & $<0.01$ & $<0.01$ & $<0.01$ & $<0.01$ & 0.008 & $<0.005$ & $<0.005$ & $<0.005$ & $<0.005$ & $<0.005$ & $<0.005$ \\
\hline & & & & & & tiary and & oterozoic & & & & & & \\
\hline G21 & $<0.002$ & 0.571 & 0.384 & 0.160 & 0.658 & 0.170 & 0.029 & 0.186 & 0.018 & 0.170 & 0.031 & 0.098 & $<0.001$ \\
\hline G22 & $<0.002$ & 0.083 & 0.067 & 0.032 & 0.163 & 0.011 & 0.014 & 0.026 & $<0.001$ & 0.027 & $<0.001$ & 0.027 & $<0.001$ \\
\hline G23 & $<0.002$ & 0.003 & $<0.005$ & $<0.002$ & 0.043 & $<0.001$ & $<0.001$ & $<0.001$ & $<0.001$ & $<0.001$ & $<0.001$ & 0.012 & $<0.001$ \\
\hline G40 & $<0.002$ & 0.093 & 0.097 & 0.022 & 0.236 & 0.087 & $<0.001$ & 0.101 & $<0.001$ & 0.072 & 0.015 & 0.027 & $<0.001$ \\
\hline G41 & $<0.002$ & 0.109 & 0.136 & 0.037 & 0.209 & 0.027 & 0.015 & 0.081 & $<0.001$ & 0.059 & $<0.001$ & 0.035 & $<0.001$ \\
\hline G42 & $<0.002$ & 0.202 & 0.167 & 0.060 & 0.332 & 0.081 & $<0.001$ & 0.127 & $<0.001$ & 0.088 & 0.014 & 0.054 & $<0.001$ \\
\hline G43 & $<0.002$ & $<0.005$ & $<0.005$ & $<0.002$ & $<0.004$ & 0.029 & 0.015 & 0.037 & 0.001 & $<0.001$ & 0.011 & 0.021 & $<0.001$ \\
\hline G44 & 0.030 & $<0.005$ & $<0.005$ & 0.024 & $<0.004$ & -0.001 & $<0.001$ & 0.026 & $<0.001$ & $<0.001$ & $<0.001$ & 0.014 & $<0.001$ \\
\hline
\end{tabular}


Appendix 1- Continued. Chemical analyses of stream and spring water samples from watersheds underlain by the ten dominant rock composition types in the Grand Mesa, Uncompahgre, and Gunnison National Forests, Colorado.

\begin{tabular}{|c|c|c|c|c|c|c|c|c|c|c|}
\hline Sample no. & $\begin{array}{c}\mathrm{Yb} \\
\mu \mathrm{g} / \mathrm{L}\end{array}$ & $\begin{array}{c}\mathrm{Lu} \\
\mu \mathrm{g} / \mathrm{L}\end{array}$ & $\begin{array}{c}\mathrm{Hf} \\
\mu \mathrm{g} / \mathrm{L}\end{array}$ & $\begin{array}{c}W \\
\mu \mathrm{g} / \mathrm{L}\end{array}$ & $\begin{array}{c}\mathrm{Re} \\
\mu \mathrm{g} / \mathrm{L}\end{array}$ & $\begin{array}{c}\mathrm{TI} \\
\mu \mathrm{g} / \mathrm{L}\end{array}$ & $\begin{array}{c}\mathrm{Pb} \\
\mu \mathrm{g} / \mathrm{L}\end{array}$ & $\begin{array}{c}\mathrm{Bi} \\
\mu \mathrm{g} / \mathrm{L}\end{array}$ & $\begin{array}{c}\text { Th } \\
\mu \mathrm{g} / \mathrm{L}\end{array}$ & $\begin{array}{c}\mathrm{U} \\
\mu \mathrm{g} / \mathrm{L}\end{array}$ \\
\hline \multicolumn{11}{|c|}{ Tertiary basalt } \\
\hline G14 & 0.027 & $<0.001$ & $<0.002$ & $<0.01$ & $<0.001$ & $<0.005$ & $<0.1$ & $<0.005$ & 0.069 & 0.15 \\
\hline G15 & 0.033 & $<0.001$ & $<0.002$ & 3.775 & $<0.001$ & $<0.005$ & 1.42 & $<0.005$ & 0.100 & 0.07 \\
\hline G16 & 0.041 & $<0.001$ & 0.033 & 0.551 & $<0.001$ & $<0.005$ & $<0.1$ & $<0.005$ & 0.092 & 0.06 \\
\hline G17 & $<0.001$ & $<0.001$ & $<0.002$ & 0.112 & $<0.001$ & $<0.005$ & $<0.1$ & $<0.005$ & 0.073 & 0.04 \\
\hline & & & & & ertiary as & $v$ tuff & & & & \\
\hline G45 & $<0.001$ & $<0.001$ & 0.068 & $<0.01$ & $<0.001$ & 0.054 & $<0.1$ & $<0.005$ & 0.567 & 0.19 \\
\hline G46 & $<0.001$ & 0.013 & 0.077 & $<0.01$ & $<0.001$ & 0.059 & 1.10 & $<0.005$ & 0.501 & 0.20 \\
\hline G56 & 0.014 & $<0.001$ & 0.112 & $<0.01$ & $<0.001$ & $<0.005$ & $<0.1$ & $<0.005$ & 0.072 & 0.06 \\
\hline G57 & 0.021 & $<0.001$ & $<0.002$ & $<0.01$ & $<0.001$ & $<0.005$ & $<0.1$ & $<0.005$ & 0.097 & 0.02 \\
\hline G58 & 0.024 & $<0.001$ & $<0.002$ & $<0.01$ & $<0.001$ & $<0.005$ & $<0.1$ & $<0.005$ & 0.130 & 0.01 \\
\hline & & & & & Tertiary q & latite & & & & \\
\hline $\mathrm{C} 12$ & 0.01 & - & - & $<0.02$ & - & - & $<0.05$ & $<0.005$ & 0.007 & 0.08 \\
\hline $\mathrm{C} 13$ & 0.17 & - & - & $<0.02$ & - & - & 0.06 & 0.007 & 0.15 & 0.32 \\
\hline C14 & 0.03 & - & - & $<0.02$ & - & - & $<0.05$ & $<0.005$ & 0.04 & 0.17 \\
\hline C15 & 0.02 & - & - & $<0.02$ & - & - & $<0.05$ & $<0.005$ & 0.02 & 0.09 \\
\hline & & & & & Tertiary & & & & & \\
\hline G47 & $<0.001$ & $<0.001$ & 0.034 & $<0.01$ & $<0.001$ & $<0.005$ & $<0.1$ & $<0.005$ & 0.297 & $<0.001$ \\
\hline G48 & $<0.001$ & $<0.001$ & 0.047 & $<0.01$ & $<0.001$ & $<0.005$ & $<0.1$ & $<0.005$ & 0.365 & 0.10 \\
\hline G49 & $<0.001$ & $<0.001$ & 0.047 & $<0.01$ & $<0.001$ & $<0.005$ & $<0.1$ & $<0.005$ & 0.280 & 0.28 \\
\hline G50 & 0.014 & $<0.001$ & 0.020 & $<0.01$ & $<0.001$ & $<0.005$ & $<0.1$ & $<0.005$ & 0.160 & 0.19 \\
\hline G51 & $<0.001$ & $<0.001$ & $<0.002$ & $<0.01$ & $<0.001$ & $<0.005$ & $<0.1$ & $<0.005$ & 0.176 & 0.24 \\
\hline G52 & $<0.001$ & $<0.001$ & $<0.002$ & $<0.01$ & $<0.001$ & $<0.005$ & $<0.1$ & $<0.005$ & 0.124 & 0.13 \\
\hline G54 & 0.021 & $<0.001$ & $<0.002$ & $<0.01$ & $<0.001$ & $<0.005$ & $<0.1$ & $<0.005$ & 0.122 & 0.20 \\
\hline G55 & $<0.001$ & $<0.001$ & 0.030 & $<0.01$ & $<0.001$ & $<0.005$ & $<0.1$ & $<0.005$ & 0.172 & 0.23 \\
\hline & & & & & tiary sedi & ry rock & & & & \\
\hline G01 & 0.045 & 0.035 & 0.217 & 0.175 & $<0.001$ & 0.062 & $<0.1$ & 1.028 & 1.517 & 2.29 \\
\hline G02 & 0.026 & 0.022 & 0.192 & 0.192 & 0.016 & $<0.005$ & 1.19 & $<0.005$ & 0.841 & 8.84 \\
\hline G03 & $<0.001$ & $<0.001$ & 0.048 & $<0.01$ & $<0.001$ & $<0.005$ & 2.87 & $<0.005$ & 0.301 & 1.22 \\
\hline G04 & 0.023 & $<0.001$ & 0.026 & $<0.01$ & $<0.001$ & $<0.005$ & $<0.1$ & $<0.005$ & 0.225 & 0.95 \\
\hline G05 & $<0.001$ & $<0.001$ & 0.062 & $<0.01$ & $<0.001$ & $<0.005$ & $<0.1$ & $<0.005$ & 0.248 & 1.70 \\
\hline G06 & $<0.001$ & $<0.001$ & 0.054 & $<0.01$ & $<0.001$ & $<0.005$ & $<0.1$ & $<0.005$ & 0.204 & 0.39 \\
\hline G07 & 0.017 & $<0.001$ & 0.032 & $<0.01$ & $<0.001$ & $<0.005$ & $<0.1$ & $<0.005$ & 0.183 & 0.68 \\
\hline & & & & & ous Mes & e Formati & & & & \\
\hline G32 & $<0.001$ & $<0.001$ & $<0.002$ & $<0.01$ & $<0.001$ & $<0.005$ & $<0.1$ & $<0.005$ & 0.0015 & 0.09 \\
\hline G33 & $<0.001$ & $<0.001$ & $<0.002$ & $<0.01$ & $<0.001$ & $<0.005$ & $<0.1$ & $<0.005$ & 0.023 & 0.27 \\
\hline G34 & $<0.001$ & $<0.001$ & $<0.002$ & $<0.01$ & $<0.001$ & $<0.005$ & $<0.1$ & $<0.005$ & 0.0015 & 0.51 \\
\hline G35 & $<0.001$ & $<0.001$ & $<0.002$ & $<0.01$ & $<0.001$ & $<0.005$ & $<0.1$ & $<0.005$ & 0.0015 & 0.08 \\
\hline G36 & $<0.001$ & $<0.001$ & $<0.002$ & 0.149 & $<0.001$ & $<0.005$ & $<0.1$ & $<0.005$ & 0.0015 & 0.12 \\
\hline G37 & 0.001 & $<0.001$ & $<0.002$ & $<0.01$ & $<0.001$ & $<0.005$ & $<0.1$ & $<0.005$ & 0.0015 & 0.08 \\
\hline G38 & $<0.001$ & $<0.001$ & $<0.002$ & $<0.01$ & $<0.001$ & $<0.005$ & $<0.1$ & $<0.005$ & 0.0015 & 0.09 \\
\hline G39 & $<0.001$ & $<0.001$ & $<0.002$ & $<0.01$ & $<0.001$ & 0.054 & $<0.1$ & $<0.005$ & 0.021 & 0.13 \\
\hline & & & & & taceous & s Shale & & & & \\
\hline G19 & 0.021 & $<0.001$ & $<0.002$ & $<0.01$ & $<0.001$ & $<0.005$ & $<0.1$ & $<0.005$ & 0.040 & 0.35 \\
\hline G20 & $<0.001$ & $<0.001$ & $<0.002$ & $<0.01$ & 0.001 & $<0.005$ & $<0.1$ & $<0.005$ & 0.041 & 0.58 \\
\hline G24 & $<0.001$ & $<0.001$ & $<0.002$ & $<0.01$ & $<0.001$ & $<0.005$ & $<0.1$ & $<0.005$ & 0.037 & 0.45 \\
\hline G25 & $<0.001$ & $<0.001$ & $<0.002$ & $<0.01$ & $<0.001$ & $<0.005$ & $<0.1$ & $<0.005$ & 0.031 & 0.22 \\
\hline G26 & $<0.001$ & $<0.001$ & $<0.002$ & $<0.01$ & $<0.001$ & $<0.005$ & $<0.1$ & $<0.005$ & 0.062 & 0.12 \\
\hline G27 & 0.014 & $<0.001$ & $<0.002$ & $<0.01$ & $<0.001$ & $<0.005$ & $<0.1$ & $<0.005$ & 0.020 & 0.27 \\
\hline G28 & $<0.001$ & $<0.001$ & $<0.002$ & $<0.01$ & 0.026 & 0.055 & $<0.1$ & $<0.005$ & 0.049 & 0.14 \\
\hline G29 & $<0.001$ & $<0.001$ & $<0.002$ & $<0.01$ & $<0.001$ & $<0.005$ & $<0.1$ & $<0.005$ & 0.021 & 0.34 \\
\hline G30 & $<0.001$ & $<0.001$ & $<0.002$ & $<0.01$ & 0.011 & $<0.005$ & $<0.1$ & $<0.005$ & 0.022 & 0.52 \\
\hline G31 & $<0.001$ & $<0.001$ & $<0.002$ & $<0.01$ & $<0.001$ & $<0.005$ & $<0.1$ & $<0.005$ & 0.022 & 0.12 \\
\hline & & & & & sozoic sed & ary rock & & & & \\
\hline G09 & $<0.001$ & $<0.001$ & $<0.002$ & $<0.01$ & 0.010 & $<0.005$ & $<0.1$ & $<0.005$ & 0.094 & 1.43 \\
\hline G10 & $<0.001$ & $<0.001$ & $<0.002$ & $<0.01$ & $<0.001$ & $<0.005$ & 1.66 & $<0.005$ & 0.077 & 2.33 \\
\hline G11 & $<0.001$ & $<0.001$ & $<0.002$ & $<0.01$ & 0.026 & $<0.005$ & $<0.1$ & $<0.005$ & 0.065 & 5.78 \\
\hline G12 & $<0.001$ & $<0.001$ & $<0.002$ & $<0.01$ & 0.010 & $<0.005$ & $<0.1$ & $<0.005$ & 0.079 & 2.12 \\
\hline G13 & 0.031 & $<0.001$ & $<0.002$ & $<0.01$ & 0.019 & $<0.005$ & $<0.1$ & $<0.005$ & 0.045 & 3.70 \\
\hline & & & & & ozoic sec & ary rock & & & & \\
\hline $\mathrm{C} 01$ & $<0.005$ & - & - & 0.07 & - & - & $<0.05$ & 0.005 & 0.02 & 0.84 \\
\hline $\mathrm{C} 02$ & $<0.005$ & - & - & 0.05 & - & - & $<0.05$ & $<0.005$ & 0.007 & 1.22 \\
\hline $\mathrm{C} 03$ & $<0.005$ & - & - & 0.05 & - & - & $<0.05$ & $<0.005$ & 0.006 & 0.69 \\
\hline $\mathrm{C} 04$ & 0.01 & - & - & 0.03 & - & - & $<0.05$ & $<0.005$ & $<0.005$ & 0.13 \\
\hline $\mathrm{C} 05$ & $<0.005$ & - & - & $<0.02$ & - & - & $<0.05$ & $<0.005$ & 0.005 & 0.26 \\
\hline $\mathrm{C} 06$ & $<0.005$ & - & - & 0.03 & - & - & $<0.05$ & $<0.005$ & $<0.005$ & 0.49 \\
\hline $\mathrm{C} 07$ & $<0.005$ & - & - & $<0.02$ & - & - & $<0.05$ & $<0.005$ & 0.006 & 1.08 \\
\hline $\mathrm{C} 08$ & $<0.005$ & - & - & 0.03 & - & - & $<0.05$ & $<0.005$ & 0.006 & 0.76 \\
\hline $\mathrm{C} 09$ & $<0.005$ & - & - & 0.05 & - & - & $<0.05$ & $<0.005$ & 0.01 & 0.54 \\
\hline $\mathrm{C} 10$ & $<0.005$ & - & - & 0.02 & - & - & $<0.05$ & $<0.005$ & 0.01 & 0.70 \\
\hline C11 & $<0.005$ & - & - & $<0.02$ & - & - & $<0.05$ & $<0.005$ & 0.005 & 0.28 \\
\hline $\mathrm{C} 16$ & 0.006 & - & - & $<0.02$ & - & - & $<0.05$ & $<0.005$ & 0.005 & 0.70 \\
\hline $\mathrm{C} 17$ & $<0.005$ & - & - & $<0.02$ & - & - & $<0.05$ & $<0.005$ & 0.008 & 0.74 \\
\hline C18 & $<0.005$ & - & - & $<0.02$ & - & - & $<0.05$ & $<0.005$ & 0.006 & 0.61 \\
\hline $\mathrm{C} 19$ & $<0.005$ & - & - & $<0.02$ & - & - & $<0.05$ & $<0.005$ & $<0.005$ & 0.48 \\
\hline & & & & & ary and $P$ & zoic rock & & & & \\
\hline G21 & 0.087 & 0.016 & $<0.002$ & $<0.01$ & $<0.001$ & $<0.005$ & 1.31 & $<0.005$ & 0.079 & 7.27 \\
\hline G22 & 0.017 & $<0.001$ & $<0.002$ & $<0.01$ & $<0.001$ & $<0.005$ & 1.07 & $<0.005$ & 0.046 & 0.62 \\
\hline G23 & $<0.001$ & $<0.001$ & $<0.002$ & $<0.01$ & 0.017 & $<0.005$ & $<0.1$ & $<0.005$ & 0.023 & 0.59 \\
\hline G40 & 0.015 & $<0.001$ & 0.002 & $<0.01$ & $<0.001$ & $<0.005$ & $<0.1$ & $<0.005$ & 0.033 & 0.17 \\
\hline G41 & 0.027 & $<0.001$ & $<0.002$ & 1.430 & $<0.001$ & $<0.005$ & 1.02 & $<0.005$ & 0.071 & 0.98 \\
\hline G42 & 0.027 & 0.013 & 0.043 & 0.107 & $<0.001$ & $<0.005$ & $<0.1$ & $<0.005$ & 0.050 & 1.36 \\
\hline G43 & $<0.001$ & 0.017 & 0.206 & 0.261 & $<0.001$ & 0.052 & $<0.1$ & $<0.005$ & 0.375 & 0.37 \\
\hline G44 & $<0.001$ & 0.019 & 0.045 & $<0.01$ & $<0.001$ & 0.068 & $<0.1$ & $<0.005$ & 0.333 & 0.63 \\
\hline
\end{tabular}


Appendix 2 Chemical analyses of stream water samples from watersheds underlain by the Sunshine Peak Tuff, Redcloud Peak area, Colorado. [Summarized in table 19]

\begin{tabular}{|c|c|c|c|c|c|c|c|c|c|c|c|c|c|c|c|}
\hline \multirow[t]{2}{*}{ Site } & \multicolumn{3}{|c|}{ Latitude } & \multicolumn{3}{|c|}{ Longitude } & \multirow{2}{*}{\multicolumn{2}{|c|}{ Water Type }} & \multirow{2}{*}{$\begin{array}{l}\text { Flow, gallons } \\
\text { per minute }\end{array}$} & \multirow{2}{*}{\multicolumn{4}{|c|}{ Comments }} & \multirow{2}{*}{$\begin{array}{c}\text { Temperature } \\
{ }^{\circ} \mathrm{C} \\
\end{array}$} & \multirow[t]{2}{*}{$\mathrm{pH}$} \\
\hline & Degree & Minute & Second & Degree & Minute & Second & & & & & & & & & \\
\hline RW02 & 37 & 58 & 59 & 107 & 29 & 7 & \multicolumn{2}{|c|}{ Unnamed stream } & 15 & \multicolumn{4}{|c|}{ No precipitates } & 8 & 7.09 \\
\hline RW10 & 37 & 56 & 40 & 107 & 28 & 42 & \multicolumn{2}{|c|}{ Rock Creek } & 5 & \multicolumn{4}{|c|}{ Slight staining } & 9 & 6.73 \\
\hline RW11 & 37 & 56 & 37 & 107 & 28 & 9 & Cooper Cre & & 10 & & Al oxide co & igs on $\mathrm{fl}$ & & 10 & 5.17 \\
\hline RW12 & 37 & 56 & 54 & 107 & 26 & 19 & South Fork Silve & Creek & 20 & & Al oxide co & igs on $\mathrm{f}$ & & 8 & 4.92 \\
\hline RW14 & 37 & 56 & 56 & 107 & 26 & 25 & Unnamed str & & 1 & Abund & dant recent & oxide $\mathrm{pr}$ & pitates & 13 & 3.58 \\
\hline RW15 & 37 & 56 & 46 & 107 & 26 & 39 & Unnamed str & & 0.25 & & Slight I & taining & & 5 & 6.08 \\
\hline RW16 & 37 & 56 & 28 & 107 & 27 & 13 & Unnamed str & & 0.75 & & Slight I & taining & & 9 & 4.17 \\
\hline RW17 & 38 & 0 & 12 & 107 & 21 & 45 & Alpine Gul & & 18 & & Slightly mur & Fe stail & & 10 & 7 \\
\hline RW21 & 37 & 54 & 29 & 107 & 22 & 31 & Unnamed str & & 1 & & & & & 12 & 6.91 \\
\hline RW22 & 37 & 54 & 26 & 107 & 22 & 49 & Bent Cree & & 2 & & & & & 12 & 7 \\
\hline RW23 & 37 & 54 & 24 & 107 & 25 & 55 & Unnamed str & & 1 & & & & & 11 & 7.42 \\
\hline RW24 & 37 & 54 & 44 & 107 & 26 & 27 & Unnamed str & & 1 & & & & & 11 & 7.6 \\
\hline RW25 & 37 & 55 & 5 & 107 & 26 & 51 & Unnamed str & & 1 & & & & & 8 & 7.57 \\
\hline RW26 & 37 & 56 & 9 & 107 & 27 & 30 & Silver Cree & & 2 & & & & & 14 & 6.06 \\
\hline RW27 & 37 & 54 & 20 & 107 & 24 & 33 & Unnamed str & & 1 & & & & & 11 & 7.05 \\
\hline RW30 & 37 & 58 & 22 & 107 & 26 & 33 & Unnamed str & & 1 & & & & & 10 & 4.42 \\
\hline RW31 & 37 & 58 & 24 & 107 & 26 & 36 & Upper Cooper & eek & 1 & & & & & 8 & 6.4 \\
\hline RW32 & 37 & 57 & 53 & 107 & 27 & 4 & Unnamed str & & 1 & & & & & 6 & 3.9 \\
\hline RW33 & 37 & 57 & 19 & 107 & 27 & 50 & Unnamed str & & 1 & & & & & 10 & 6.6 \\
\hline Site & $\begin{array}{c}\text { Conductivity } \\
\mu \mathrm{S} / \mathrm{cm}\end{array}$ & $\begin{array}{c}\mathrm{Ca} \\
\mathrm{mg} / \mathrm{L}\end{array}$ & $\begin{array}{c}\mathrm{Mg} \\
\mathrm{mg} / \mathrm{L}\end{array}$ & $\begin{array}{c}\mathrm{Na} \\
\mathrm{mg} / \mathrm{L}\end{array}$ & $\begin{array}{c}\mathrm{K} \\
\mathrm{mg} / \mathrm{L}\end{array}$ & & $\begin{array}{l}\text { Alkalinity } \\
\mathrm{mg}^{-} \mathrm{L} \mathrm{HCO}_{3}^{-}\end{array}$ & $\begin{array}{c}\mathrm{SO}_{4} \\
\mathrm{mg} / \mathrm{L}\end{array}$ & $\begin{array}{c}\mathrm{Cl} \\
\mathrm{mg} / \mathrm{L}\end{array}$ & $\begin{array}{c}\mathrm{F} \\
\mathrm{mg} / \mathrm{L}\end{array}$ & $\begin{array}{l}\mathrm{NO}_{3} \\
\mathrm{mg} / \mathrm{L}\end{array}$ & $\begin{array}{c}\mathrm{Al} \\
\mathrm{mg} / \mathrm{L}\end{array}$ & $\begin{array}{c}\mathrm{Mn} \\
\mathrm{mg} / \mathrm{L}\end{array}$ & $\begin{array}{c}\mathrm{Fe} \\
\mathrm{mg} / \mathrm{L}\end{array}$ & $\begin{array}{c}\mathrm{Cu} \\
\mu \mathrm{g} / \mathrm{L}\end{array}$ \\
\hline RW02 & 110 & 15 & 1.7 & 0.7 & 0.5 & & 29 & 32 & 0.15 & 0.12 & 2 & 0.005 & 0.007 & 0.02 & 0.7 \\
\hline RW10 & 117 & 14 & 2.5 & 0.4 & 0.9 & & 12 & 42 & 0.07 & 0.09 & 0.15 & 0.005 & 0.007 & 0.01 & 0.7 \\
\hline RW11 & 117 & 12 & 1.5 & 1 & 1.2 & & 15 & 45 & 0.07 & 0.27 & 0.32 & 1.2 & 0.5 & 0.04 & 1 \\
\hline RW12 & 127 & 12 & 2 & 0.6 & 1.9 & & 0.1 & 49 & 0.15 & 0.19 & 1.1 & 1.6 & 0.52 & 0.007 & 4 \\
\hline RW14 & 320 & 22 & 4.5 & 2.2 & 4.5 & & 0.1 & 106 & 0.14 & 0.96 & 0.15 & 2.62 & 2 & 0.45 & 3 \\
\hline RW15 & 70 & 7.8 & 1.2 & 0.6 & 1.7 & & 13 & 23 & 0.14 & 0.15 & 0.15 & 0.005 & 0.007 & 0.02 & 0.7 \\
\hline RW16 & 148 & 11 & 2 & 0.5 & 3.6 & & 0.1 & 53 & 0.15 & 0.33 & 0.15 & 1.7 & 1.2 & 0.07 & 3 \\
\hline RW17 & 128 & 15 & 2.4 & 2 & 0.9 & & 18 & 43 & 0.1 & 0.18 & 0.15 & 0.005 & 0.02 & 0.27 & 0.7 \\
\hline RW21 & 93 & 12 & 1.4 & 1.2 & 0.7 & & 29 & 23 & 0.13 & 0.07 & 0.15 & 0.005 & 0.007 & 0.01 & 0.7 \\
\hline RW22 & 94 & 12 & 1.4 & 1.2 & 0.7 & & 15 & 23 & 0.11 & 0.08 & 0.15 & 0.005 & 0.007 & 0.03 & 0.7 \\
\hline RW23 & 121 & 18 & 1.6 & 2.3 & 0.3 & & 45 & 16 & 0.15 & 0.32 & 0.15 & 0.005 & 0.007 & 0.02 & 0.7 \\
\hline RW24 & 210 & 33 & 2 & 4.4 & 1.2 & & 94 & 24 & 0.17 & 0.28 & 0.15 & 0.005 & 0.007 & 0.02 & 0.7 \\
\hline RW25 & 87 & 11 & 1.2 & 1.1 & 1 & & 13 & 24 & 0.11 & 0.09 & 0.15 & 0.005 & 0.007 & 0.01 & 0.7 \\
\hline RW26 & 129 & 14 & 2.4 & 1.1 & 1.7 & & 0.1 & 50 & 0.13 & 0.2 & 0.59 & 0.3 & 0.26 & 0.03 & 3 \\
\hline RW27 & 44 & 6.3 & 0.5 & 0.9 & 0.5 & & 23 & 6.9 & 0.13 & 0.08 & 0.15 & 0.005 & 0.007 & 0.04 & 0.7 \\
\hline RW30 & 140 & 12 & 1.4 & 1.2 & 1.2 & & 0.1 & 52 & 0.07 & 0.26 & 0.37 & 2.1 & 0.67 & 0.07 & 2 \\
\hline RW31 & 55 & 7.6 & 0.7 & 0.4 & 0.4 & & 15 & 13 & 0.18 & 0.12 & 0.15 & 0.005 & 0.007 & 0.01 & 0.7 \\
\hline RW32 & 194 & 14 & 2.3 & 1.1 & 2.3 & & 0.1 & 74 & 0.17 & 0.69 & 0.15 & 4.4 & 0.53 & 0.04 & 6 \\
\hline RW33 & 47 & 6.7 & 0.7 & 0.4 & 0.5 & & 20 & 10 & 0.07 & 0.03 & 0.15 & 0.005 & 0.007 & 0.02 & 0.7 \\
\hline
\end{tabular}


Appendix 2-Continued. Chemical analyses of stream water samples from watersheds underlain by the Sunshine Peak Tuff, Redcloud Peak area, Colorado. [Summarized in table 19]

\begin{tabular}{|c|c|c|c|c|c|c|c|c|c|c|c|c|c|c|c|}
\hline Site & $\begin{array}{c}\mathrm{Zn} \\
\mu \mathrm{g} / \mathrm{L}\end{array}$ & $\begin{array}{c}\text { Co } \\
\mu \mathrm{g} / \mathrm{L}\end{array}$ & $\begin{array}{c}\mathrm{Ni} \\
\mu \mathrm{g} / \mathrm{L}\end{array}$ & $\begin{array}{c}\text { Mo } \\
\mu \mathrm{g} / \mathrm{L}\end{array}$ & $\begin{array}{c}\text { As } \\
\mu \mathrm{g} / \mathrm{L}\end{array}$ & $\begin{array}{c}U \\
\mu \mathrm{g} / \mathrm{L}\end{array}$ & $\begin{array}{c}\mathrm{Li} \\
\mu \mathrm{g} / \mathrm{L}\end{array}$ & $\begin{array}{c}\mathrm{Be} \\
\mu \mathrm{g} / \mathrm{L}\end{array}$ & $\begin{array}{c}\mathrm{Sc} \\
\mu \mathrm{g} / \mathrm{L}\end{array}$ & $\begin{array}{c}\mathrm{Cr} \\
\mu \mathrm{g} / \mathrm{L}\end{array}$ & $\begin{array}{c}\mathrm{Rb} \\
\mu \mathrm{g} / \mathrm{L}\end{array}$ & $\begin{array}{c}\mathrm{Sr} \\
\mu \mathrm{g} / \mathrm{L}\end{array}$ & $\begin{array}{c}\mathrm{Y} \\
\mu \mathrm{g} / \mathrm{L}\end{array}$ & $\begin{array}{c}\mathrm{Cs} \\
\mu \mathrm{g} / \mathrm{L}\end{array}$ & $\begin{array}{c}\mathrm{Ba} \\
\mu \mathrm{g} / \mathrm{L}\end{array}$ \\
\hline RW02 & 2 & 0.7 & 0.7 & 1 & 0.7 & 0.1 & 3 & 0.15 & 2 & 0.3 & 1.5 & 120 & 0.07 & 0.2 & 3.4 \\
\hline RW10 & 7 & 0.7 & 0.7 & 0.7 & 0.7 & 0.07 & 3 & 0.2 & 3 & 0.15 & 4.1 & 55 & 0.07 & 0.15 & 4.9 \\
\hline RW11 & 90 & 1 & 2 & 0.7 & 0.7 & 2.6 & 3 & 1.7 & 2 & 0.15 & 3.6 & 54 & 8.8 & 0.15 & 14 \\
\hline RW12 & 110 & 0.7 & 2 & 0.7 & 0.7 & 6.6 & 5 & 2.9 & 3 & 0.15 & 6.8 & 39 & 9.2 & 0.15 & 8.9 \\
\hline RW14 & 280 & 12 & 7 & 0.7 & 0.7 & 3.4 & 16 & 6.9 & 7.1 & 0.15 & 21 & 56 & 9.2 & 1.8 & 6.5 \\
\hline RW15 & 10 & 0.7 & 0.7 & 0.7 & 0.7 & 0.2 & 2 & 0.6 & 4.7 & 0.15 & 6.2 & 29 & 0.2 & 0.15 & 7.5 \\
\hline RW16 & 83 & 4 & 3 & 0.7 & 0.7 & 3.5 & 8.7 & 4.3 & 6.1 & 0.15 & 18 & 35 & 3.5 & 2.5 & 26 \\
\hline RW17 & 5 & 2 & 1 & 1 & 0.7 & 0.07 & 2 & 0.15 & 5 & 0.15 & 1.9 & 160 & 0.07 & 0.15 & 18 \\
\hline RW21 & 2 & 0.7 & 0.7 & 0.7 & 0.7 & 0.3 & 4 & 0.15 & 4.8 & 0.15 & 1.9 & 140 & 0.07 & 0.15 & 4.3 \\
\hline RW22 & 2 & 0.7 & 0.7 & 0.7 & 0.7 & 0.2 & 3 & 0.15 & 4.3 & 0.15 & 1.8 & 140 & 0.07 & 0.15 & 4.1 \\
\hline RW23 & 2 & 0.7 & 0.7 & 6 & 0.7 & 2.1 & 11 & 0.15 & 5.4 & 0.2 & 1.2 & 190 & 0.07 & 0.2 & 2.4 \\
\hline RW24 & 2 & 0.7 & 0.7 & 9 & 0.7 & 8.1 & 21 & 0.15 & 5.2 & 0.5 & 2.4 & 320 & 0.07 & 0.4 & 32 \\
\hline RW25 & 2 & 0.7 & 0.7 & 1 & 0.7 & 0.1 & 2 & 0.15 & 6.9 & 0.15 & 2.1 & 38 & 0.07 & 0.15 & 5.1 \\
\hline RW26 & 100 & 1 & 2 & 0.7 & 0.7 & 2.6 & 4 & 2.5 & 6.6 & 0.3 & 6.6 & 110 & 4 & 0.2 & 14 \\
\hline RW27 & 2 & 0.7 & 0.7 & 2 & 0.7 & 0.6 & 4.7 & 0.15 & 7 & 0.2 & 1.8 & 39 & 0.1 & 0.7 & 0.9 \\
\hline RW30 & 130 & 3 & 2 & 0.7 & 0.7 & 5.2 & 3 & 3.3 & 8.9 & 0.15 & 4 & 49 & 13 & 0.15 & 14 \\
\hline RW31 & 2 & 0.7 & 0.7 & 0.7 & 0.7 & 0.07 & 0.7 & 0.15 & 8.2 & 0.15 & 0.8 & 42 & 0.07 & 0.15 & 13 \\
\hline RW32 & 93 & 3 & 0.7 & 0.7 & 1 & 4.6 & 5.7 & 1 & 8.2 & 0.2 & 9.5 & 44 & 13 & 1.1 & 7.2 \\
\hline RW33 & 2 & 0.7 & 0.7 & 0.7 & 0.7 & 0.07 & 0.7 & 0.15 & 8.1 & 0.15 & 1.1 & 79 & 0.07 & 0.2 & 14 \\
\hline Site & $\begin{array}{c}\mathrm{La} \\
\mu \mathrm{g} / \mathrm{L}\end{array}$ & $\begin{array}{c}\mathrm{Ce} \\
\mu \mathrm{g} / \mathrm{L}\end{array}$ & $\begin{array}{c}\mathrm{Pr} \\
\mu \mathrm{g} / \mathrm{L}\end{array}$ & $\begin{array}{c}\mathrm{Nd} \\
\mu \mathrm{g} / \mathrm{L}\end{array}$ & $\begin{array}{c}\mathrm{Sm} \\
\mu \mathrm{g} / \mathrm{L}\end{array}$ & $\begin{array}{c}\mathrm{Eu} \\
\mu \mathrm{g} / \mathrm{L}\end{array}$ & $\begin{array}{c}\mathrm{Gd} \\
\mu \mathrm{g} / \mathrm{L}\end{array}$ & $\begin{array}{c}\text { Dy } \\
\mu \mathrm{g} / \mathrm{L}\end{array}$ & $\begin{array}{c}\mathrm{Yb} \\
\mu \mathrm{g} / \mathrm{L}\end{array}$ & & & & & & \\
\hline RW02 & 66 & 0.07 & 0.07 & 0.07 & 0.07 & 0.07 & 0.07 & 0.07 & 0.07 & & & & & & \\
\hline RW10 & 0.2 & 0.07 & 0.07 & 0.07 & 0.07 & 0.07 & 0.07 & 0.07 & 0.07 & & & & & & \\
\hline RW11 & 7 & 14 & 2.2 & 8.7 & 1.8 & 0.2 & 2 & 1.6 & 0.6 & & & & & & \\
\hline RW12 & 5.8 & 10 & 1.7 & 5.8 & 1.4 & 0.2 & 1.8 & 1.5 & 0.7 & & & & & & \\
\hline RW14 & 2.9 & 6.7 & 1 & 4.7 & 1.2 & 0.2 & 1.6 & 1.3 & 0.6 & & & & & & \\
\hline RW15 & 0.2 & 0.07 & 0.07 & 0.1 & 0.07 & 0.07 & 0.07 & 0.07 & 0.07 & & & & & & \\
\hline RW16 & 1 & 2.1 & 0.4 & 1.6 & 0.3 & 0.07 & 0.4 & 0.4 & 0.2 & & & & & & \\
\hline RW17 & 0.2 & 0.07 & 0.07 & 0.07 & 0.07 & 0.07 & 0.07 & 0.07 & 0.07 & & & & & & \\
\hline RW21 & 0.07 & 0.07 & 0.07 & 0.07 & 0.07 & 0.07 & 0.07 & 0.07 & 0.07 & & & & & & \\
\hline RW22 & 0.07 & 0.07 & 0.07 & 0.07 & 0.07 & 0.07 & 0.07 & 0.07 & 0.07 & & & & & & \\
\hline RW23 & 0.1 & 0.07 & 0.07 & 0.07 & 0.07 & 0.07 & 0.07 & 0.07 & 0.07 & & & & & & \\
\hline RW24 & 0.07 & 0.07 & 0.07 & 0.07 & 0.07 & 0.07 & 0.07 & 0.07 & 0.07 & & & & & & \\
\hline RW25 & 0.2 & 0.1 & 0.07 & 0.1 & 0.07 & 0.07 & 0.07 & 0.07 & 0.07 & & & & & & \\
\hline RW26 & 2.2 & 3.5 & 0.6 & 2.4 & 0.5 & 0.07 & 0.7 & 0.5 & 0.2 & & & & & & \\
\hline RW27 & 0.07 & 0.1 & 0.07 & 0.07 & 0.07 & 0.07 & 0.07 & 0.07 & 0.07 & & & & & & \\
\hline RW30 & 9.8 & 21 & 2.8 & 10 & 2.2 & 0.2 & 2.4 & 2 & 0.9 & & & & & & \\
\hline RW31 & 0.2 & 0.07 & 0.07 & 0.2 & 0.07 & 0.07 & 0.07 & 0.07 & 0.07 & & & & & & \\
\hline RW32 & 4.1 & 13 & 2 & 9 & 2.1 & 0.3 & 2.9 & 2.2 & 0.8 & & & & & & \\
\hline RW33 & 0.07 & 0.1 & 0.07 & 0.07 & 0.07 & 0.07 & 0.07 & 0.07 & 0.07 & & & & & & \\
\hline
\end{tabular}

